Historic, Archive Document

Do not assume content reflects current scientific knowledge, policies, or practices. 
WOPEX

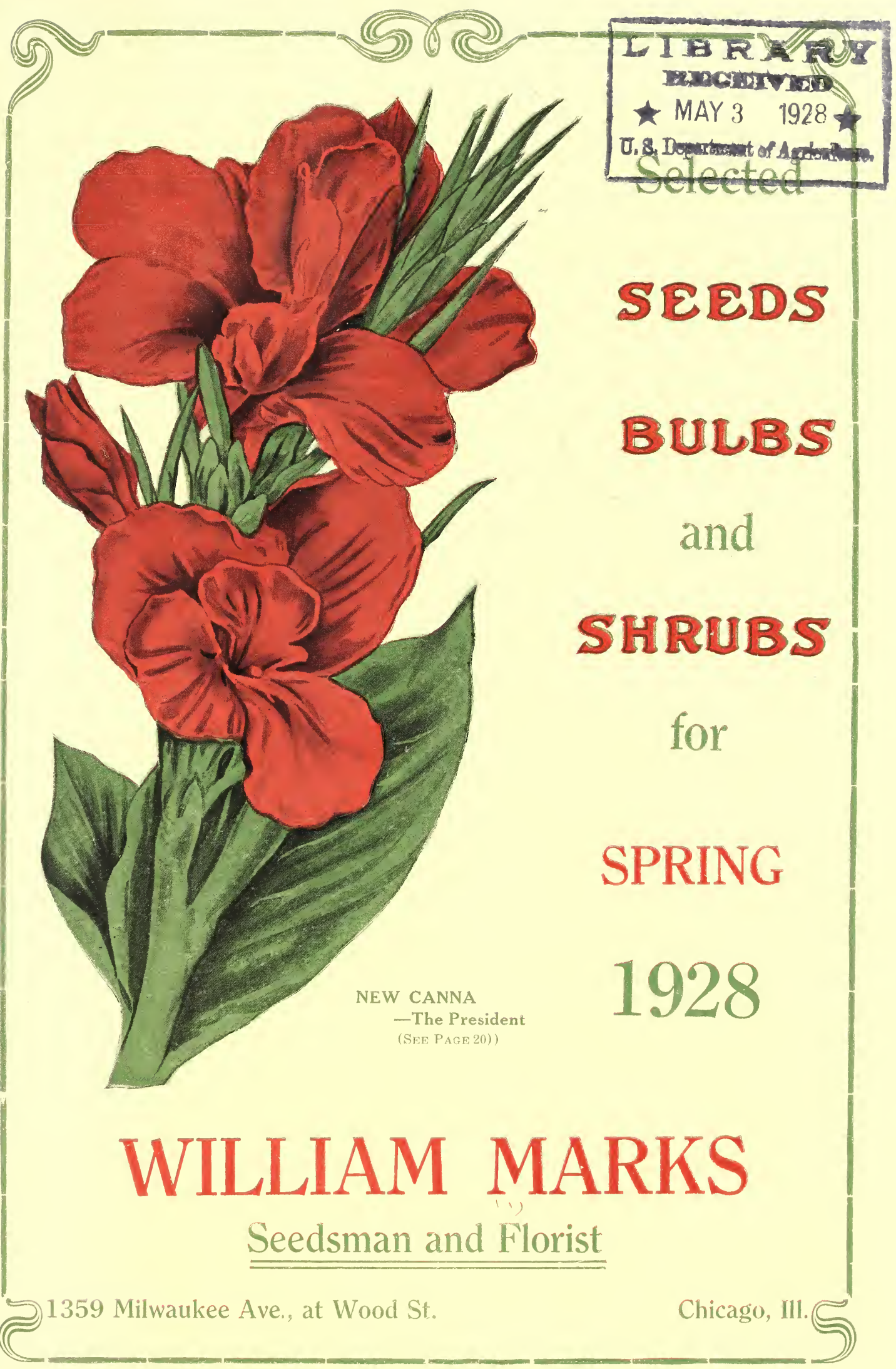




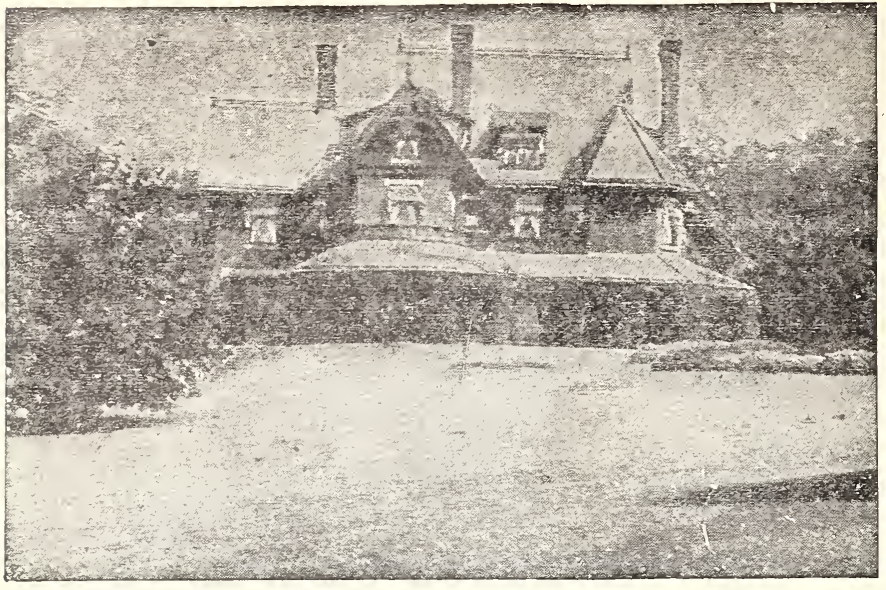

OTHER GRASS AND CEOVER SEEBS, Blue Grass. There are many people who prefer this grass to all mixtures for the formation of lawns. It has a the inost enduring grasses. $1 / 2 \mathrm{lb} .20 \mathrm{c}, 113.40 \mathrm{e}$

5 lbs. $\$ 1.75$.

Red Top. This is a quick growing grass, sultable for meadors. pastures and lawns. It thrives in almost any situation and is not ser
200.116 .558$.

White Clover. The most hardy of any variety of clover, It has a creeping habit and is desirable to sow on terraces or ilb. 750

NOTICE: Prices on insecticides and Fertilizerg are Subject to Change Without Notice.

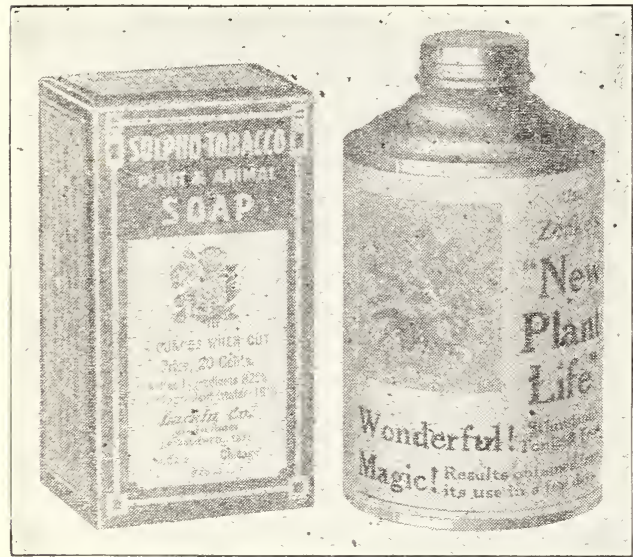

INSECTICIDES.

Arsenate of Lead, Powdor. For dusting and spraying. Solves the problem of controlling practimanner. $1 / 2$ lb. 25e, 1 lb. 10 .

Bordeaux Mixture. This is a preventive of plant diseases, especially apple scab, rust on melons, bean
hollyhocks, etc., besides rot and mildew. Lb. 40 .

Carbon Disulphide. To drive away ants and cut-worms. Per $1 \mathrm{~b} .55 \mathrm{c}$.

Hammond's Slug Shor. Kills every garden pest. Harmless to human life. 5 lb. pkg. 60c, 1 lb. car: ton, perforated top, $20 \mathrm{c}$.

Hollebore. One of the best insecticides for allaround garden use. Kills leat-eating insects, such as currant worm cut worm, rose bug, etc C.n be used ary or in solution. $1 \mathrm{oz}$. to 2 gals. of water. Price,

Lime Sulphur, Powder Form. All that is needed is the addition of water to make spraying material. It is used for the control of San Jose scale, oyster shell bark louse, and other scale insects. Per 1 b. 35 c.

Nikoteen. A fumigating and spraying material for destroying sucking insects. Best adapted for indoor use. One $3 / 4-0 z$. bottle makes four gallons of spray. Price, each 3.5c.

Sulpho-Tobacco Soap. Exterminates insects on plants and shrubs as well as on domestic animals. In oakes, 3 oz., each 15o; 9 oz., each $25 \mathrm{c}$, D sections accompany each cake.
Lawn Grass Seed

A RICH, velvety green lawn is easily obtained. - You can have one if you use our specially prepared seed. It is made up of a number of varieties ot dwarf habits.

A lawn which is produced from seed will invariably give better satisfaction than one prepared by laying down sods or turf. That made from seed will retain its verdure and velvety appearance in dry weather because the grasses in it are such as will thrive under adverse conäitions.

The Quantity to Sow. It is unwise to be economical in the quantity of seed used if the best results are desired. One pound will sow a plot of three hundred square feet; 4 bushels (56 1bs.) to the acre.

The Prioe. The price of lawn seed varies freatly according to quality. The cheap seed offered consists mostly of chaff and if used the planter will find his grass coming up in patches or very thin. If good seed is planted it will come up thick and make a good permanent lawn.

Knowing from experience of many years in both growing and dealing with the planter of seeds that the best is the cheapest in the end, quality.

OUPR SUPERIOR PARK MIXTURE.

A combination of various native and foreign dwarf growing, fine-leaved grasses, carefully balanced and blended, with a view of producing a turf that will retain its rich green color throughout the entire season. There is nothing better than th!s for the making of a luxuriant and permanent lawn. It can be used to advantage to renovate old lawns or to bring again into grass patches which have become bare. Can be Sown eithes in Spring or Fall. $1 / 2$ lb. $25 c, 1$ lb. 50c, 3
lbs 31.45 .515 s. $\$ 2.35$

\section{CHOIUE MIXTURE.}

While containing fewer and less expensive grasses, this is a good well-balanced mixture which we do not hesitate to recommend. Lb. 35 c, 3 ibs. $\$ 1.00,51 b s . \$ 1.65$. SHADY PLACE MIXTURE.

Made up of grasses selected for locations shaded by trees

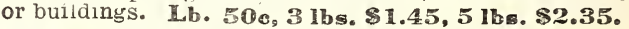

\section{Fertillizers $S^{\text {INSECTICIDES AND REMEDIES }}$}

Everyone recognizes the necessity of stimulating the fertility of the soil in some manner. On the farm this is largely accomplished by plowing under decayed manure. Concentrated fertilizers, that are inodorous, quickly applied and easy to handle are now offered.

\section{FERTLIZERS.}

Bone Meal. Ground fine, Can be used for tncoor or outdoor purposes. Stimulates lawns and pot plants. Bone Meal is the best and safest fertilizer. 5 Ibs. $45 \mathrm{c}, 10 \mathrm{lbs}$. 750. 25 lbs. $\$ 1.25$. 50 lbs. $\$ 2.00,1001 \mathrm{bs}$. $\$ 3.75$

Lawn Fertilizer. A dry odorless preparation that is pleasant to handle and absolutely free from weed seed. Apply at the rate of ten pounds to 300 square feet, either in fall or spring. $5 \mathbf{~} \mathbf{l b s} . \mathbf{4 5 c}$ $10 \mathrm{lbs}$.75c, $251 \mathrm{bs}$. \$1.25, $50 \mathrm{lbs}$. $\$ 2.00,100 \mathrm{ibs}, \$ 3.75$.

\section{SHEDP MAPURE (Pulverized)}

This is a natural manure; excellent for mixing with the soil. Strewn over and raked into the surface of the vegetable garden or placed directly in drills or hills, it promotes a ra pid, steady growth. Especially valuable for anns, contains all the constitu ents for promoting a quick, luxcolor. Hor the vegetable garden apply one pound to each four square feec. For lawns use about 1 pound to 10 square feet. For pot plants, mix one part of sheep manure to six parts of soil. Being soluble, it readily makes a to five gallons of water can be $5 \mathrm{lbs} .30 \mathrm{c}, 10 \mathrm{lbs} .50 \mathrm{c} .25 \mathrm{lbs}$. \$1.00, 50 lbs. S1.50, 100 ibs. \$3.00.

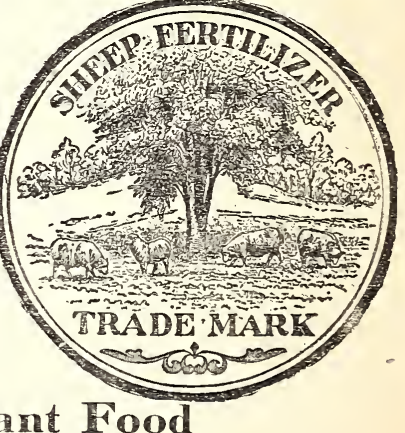

(For Potted Plants and Flowers. Use 2 to 3 tablespoonfuls of V-C Plant Food to each half peck of earth mixing with the potting soil at the time of planting, or apply near the roots, without coming into contact with them, after plants are potted. Apply five or six times per year, as required. Small can (1 Ib.), 25c; 2 lbs. can, 45c. Zenke's New Plant Life

is a compound containing Nitrogen, Potash and Phosphoric Acid, the elements which are necessary for plant production form it is easily appled, and becomes instantly available to plant absorption. It aids in producing earlier and more flowers of petter. color by renewing power in the soil. It is an ideal preparation for Price 25c. Directions for use with each can. 

for a successful season. It is our pleasure to announce that we have brought together a colleotion of Seeds, Bulbs and Plants as offered herein all of which will be found to be of the highest qualiby.

Many varieties found in the average seed catalogue have been eliminated for the reason that after years of experience have shown to possess little or no value. No mistake can be made in using those which we describe in these pages as they have been thoroughly tried and are known to be of possessing quality, soliciting an opportunity to serve you, we are willing to help you gain uxafailing success.

Having selected these goods with consideration and untiring effort in order to offer the best the market affords. We are willing to do all in our power to help you have a successful garden: but we give no warranty, express or implied, as to description, quality, production, or any other matter of the seeds, bulbs or plants we send out and will not be responsible for the crop. All items named in this catalogue will be sold on these terms only. WM. MARKS.

\section{Selected List of Vegetable Seeds.}

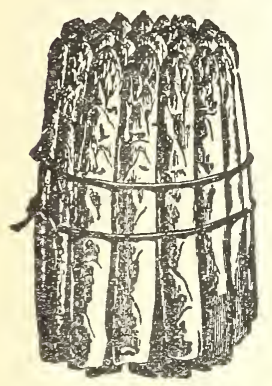

\section{BEANS-Dwarf, Wax Podded.}

Bobnen. Wadjs=Şüljen=Sorten.

\section{DAVIS KIDNEY WAX BEAN.}

The large beans are pure white; excellent for cooking, rreen or dry. The pods while young are stringless, tender, green or dry. The pods while young are stringless, tender, and of excellent flavor, very long, straight and uniform in size Pkt. $5 \mathrm{c}$; ib.30c.

GOLDEN WAX. Pods flat; golden colored; beans oval, white with more or less of two shades of reddish purple visible. One of the most delicate and finely flavored, as well as early. Pkt. 5 e. per lb. $30 \mathrm{c}$.

PROLIFIC BLACK WAX. The old standard Black Wax Bush Bean. It is so good that it is worthy of apecial notice. The pods are round, brittle of handsome golden yellow color and of buttery flavor when cooked, Pkt. 50 Per 1b. 30c.

\section{POLE LIMA BEANS.}

SEIBERT'S EARLY LIMA. In earliness, ease of shelling and quality of the green beans, this variety is far in advance of all other early Limas for either the garden or market The vine is very productive: although the pods rarely contain more than four beans, the total yield is enormous. The green shelled beans are of immense size, tender and of finest quality. Pkt. 5 c; per. $1 \mathrm{~b}$. 35c.

\section{DWAP THMA BEANS.}

Bush Limas should be planted three feet apart, dropping two or three beans fifteen inches apart in the row. Cover about 1 inch deep. Dwarf Limas require no support.

Dreer's Dwart lima. Thick pods and large thick beans, three or four in a pod. Ripens fully ten days earliar than the Pole Lima of same name. Pkt. 5e; per Ib. 35c.

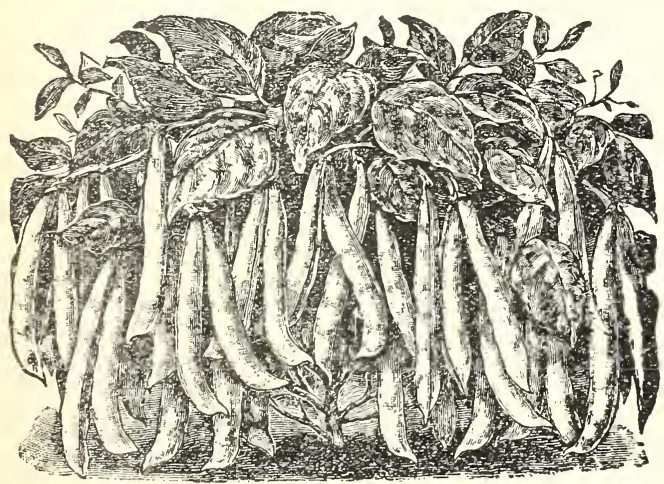

Stringless Green Pod

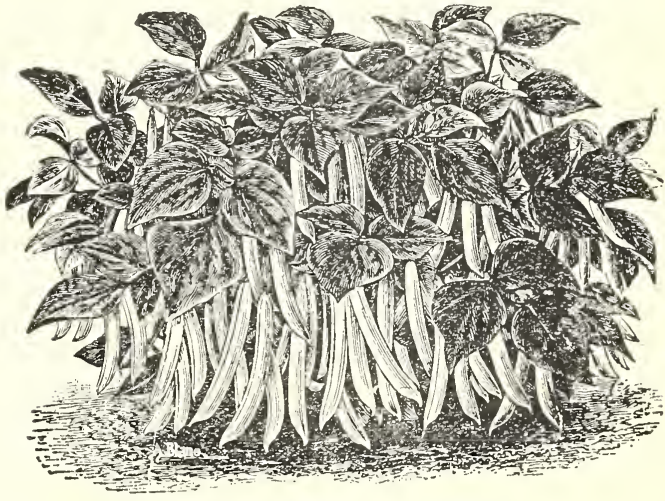

DAVIS KIDNEY WAX BEAN

BEANS-Dwar̂́, Green Pod. Bohnen, Brrüne Süljen=Sorten. BURPEE'S STRINGLESS.

This tine bean is the only absolutely stringless green-pod bean in the market. It is the earliest and most hardy green-nod sort. By repeated plantings pods may be had in constant succession from spring until cut of by frost. The plants are very productive, bearing profusely the beautifu creen pods, which are nearly round straight, broad, tender. brittle, of the tinest flavor, fleshy and entirely stringless. Pkt.5c, ner $\mathbf{l b . 3 0}$.

BOUNTIFUL.

An improved Long Yellow Six Weeks. Being earlier, hardier and producing better and larger pods and more of them. Pods grow to large size, are broad and fleshyo absolutely stringless, tender, of finest flavor and good appearance. Pkt. 5c, per 11). 30c.

\section{LONG YELLOW SIX WEEKS.}

Early upright in growth, very productive, with long. traight, thick pods of excellent quality. Seeds, when ripe. are olive-brown color. Pkt. 5o, per lib. 30c.

IMPROVED RED VALENTINE.

For snaps there is nothing superior to this variety among the green podded sorts, and many prefer it to the wax varieties. Vine erect, with dark green leaves; pods medium length curved cylindrical, with crease in back, very fleshy, crisp and tender; seed long, of medium size and unsymmetrical iv shape; pink, marbled with red. Ilkt. 5c, per $1 \mathrm{~b} .30 \mathrm{c}$. 


\section{BEETS FOR THE TABLE- - Roterüben.}

Crosby's Egyptian. Much in demand by market gardeners for forcing and early out-of-door sowing. This beet is perfect in shape, and deepest red, almost black in color. Equally good for zarly buncining as well as the fall market. Its fine color and superior quality make this one of the best beets. Pkt. 5c, oz. $15 \mathrm{c}, 1 / 1 \mathrm{1b} .25 \mathrm{c}$

Inproved Crimson Globe. The best sort for general crop. In quality one of the finest, exceedingly dark, shape globular, having only one tap root. Pirt. 5c, oz. 15 c, 1/4 Ib, 25e

\section{Mangel=Wurzel and Sugar Beets.}

MRangelwurzeln und 3uterrüben

MAMMOTI I.ONG ighteen inches long. Dark leaves; skin bright dark red; flesh white with veined rings of rose-pink. An excellent keeper; nutritious and milk-producing. Oz. 10c, $1 / 4 \mathrm{lb} .20 \mathrm{c}, 1 \mathrm{~b} .50 \mathrm{c}$

KLEIN WANZLEBEN. White flesh. Contains large amount of sugar. Oz, 10c, 3/4 1b. 20c lb. 600

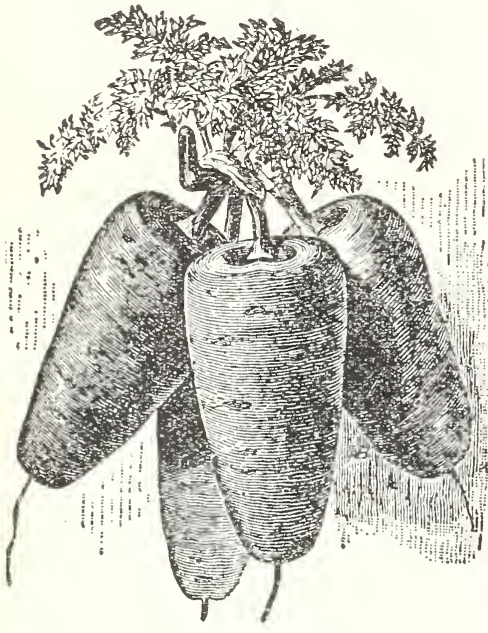

Chantenay Carrot

\section{CABBAGE- Ropfohl.}

EARLY JERSEY WAKEFIELD. Long recognized as the best, earliest marketable cabbage. In size, medium; in shape, pyramidal with pointed peak. Its uncommonly fine heading qualities, together with its fitness for wintering in cold frames, pleases the most critical gardeners. Our strain of seed is of superior quality. Ple 5c, Oz. 25c

SELECTED LATE FLAT DUTCH. It grows very large, is remarkably hardy, a sure header, uniform in shape, size and color. Few varieties can approach this for superior quality. Market gardeners grow this very extensively for a late crop. Pkt. 5c, ozc 25c

MAMMOTH $\mathbf{R E D}$ ROCK. By far the best, largest, and hardest heading red cabbage in cultivation; very uniform in size, weight, solidity and deen red color. The heads grow to weigh 10 or 12 pounds. Pht 5c, Oz. 30c

\section{SAVOY or CURLED LEAVED.}

The quality and flavor of these "curled leaved" Cabbages is very superior; grown in fall and allowed to be touched by frost, they are sweet, delicate and most delicious.

AMERICAN DRUMHEAD SAVOY. The best of its class for home use and market. Heads large, solid and compact. Has rich, sweet flavor of the cauliflower when cooked. Pkt. 5c, oz. :De

\section{CAULIFLOWER-Blumentohl.}

EARLY SNOWBALL. The leading cauliflower among cauli"lower krowers, and unquestionably the purest strain of "Snowball" cauliflower seed to be had. Heads uniform, of desirable marlset size and
of snowy whiteness. Pkt 20c.

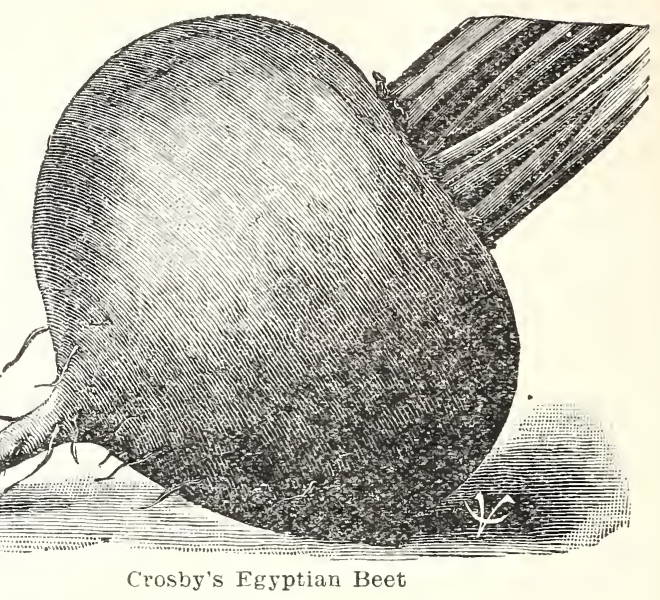

BRUSSELS SPROUTS--Eprofientohl.

ARROTS-Gelberüben.

CHANTENAY. Deep red fiesh, fine grained and sugary. One of the best for or market garden. It is early, grows about six inches long; stump rooted;

HALF LONG SCARLET NANTES. An early stump-rooted variety about inches long, that is valuable for table use. Flesh red, little core. Pkt.5c, oz.

OX HEART, or Guerande. Much esteemed either for family use or market. It is intermediate between the half long and horn varieties. Roots are about six

CORN SALAD-fiorn Ealat.

BROAD.LEAVED. A delicious salad, used during the winter and spring months as a substitute for lettuce, and also cooked and used like spinach. It will CRESS-Brunnentrefie.

UPLAND CRESS. Perennial. It is ready to use very early in spring. Has the flavor of wateI cress. Pkt. 5c, Oz. 25c.

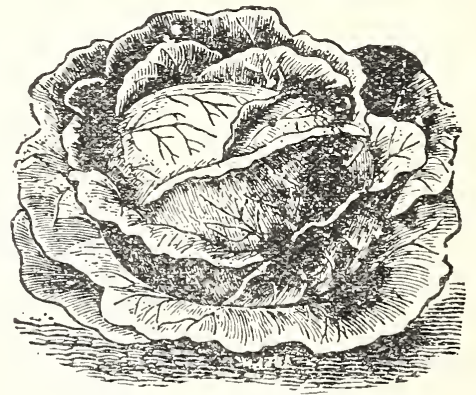

Premium Late Flat Dutch Cabbage

CHIVES-Sduitlauch.

Their green tops, which appear in early spring are used wherever the flavor of onions is desired They are entirely hardy. One or two clumps are sufficient for a family garden. Clnmps 10c each.

\section{CHERVIL- Ierbel.}

CHERVIL. A hardy annual worthy of more general use for flavoring and garnishing. The curled variety is even more beautif $x$ than parsley Plkt. 5c. Oz. 25c 


\section{CELERY-Sellerie.}

GOLDEN SELF BLANCHING. The best of all early self blanching varieties. First introduced in America in 1884, this is decidedly better in quality than the White Plume. It is ready for use nearly as early, blanches as easily, and is larger in size, as well as finer in quality. It is of dwarf compact habit, with thick solid heavily ribbed stalks which blanch easily to a clear waxen yellow. Pkt. 10o.

GIANT GOLDEN HEART. Large size, beautiful color, crisp and deliciously flavored. One of the best celeries for market, and for home use. Pkt. 5c.

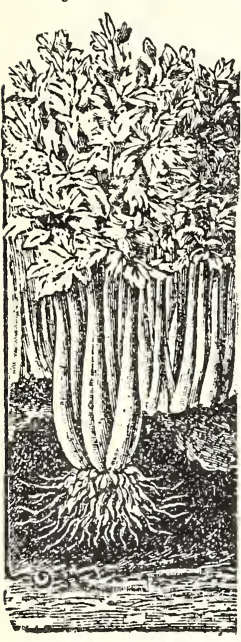

WHITE PLUME. The peculiarity of this leading variety is that the inner leaves and heart are naturally white, so that by closing the stalks, either by tying or by drawing the soil close about the plant and pressing it together with the hands, the blanching is completed. It is the earliest Celery in Pkt. 50.

GERMAN CELERY or CELERIAC-Inollen Sellerie.

Produces larger turnip-like roots which keep well for winter use; it is highly esteemed either cooked for flavoring soup or sliced and used with vinegar, making an excellent salad. It is cultivated like celery, little or no earthing being required. Ready for use in October.

LARGE SMOOTH PRAGUE. Has a large smooth root, and is the finest of all celeriac Pkt.5e, oz. 20o.

\section{CHARD}

OR SPINACH BEET. Few people realize the great merits of this vegetable. While it is classed among beets, it makes no root whatever, the top only being used. It is cooked and served like spinach, which it resembles in taste.

Giant Golden Pkt. 5e, oz. 15c.

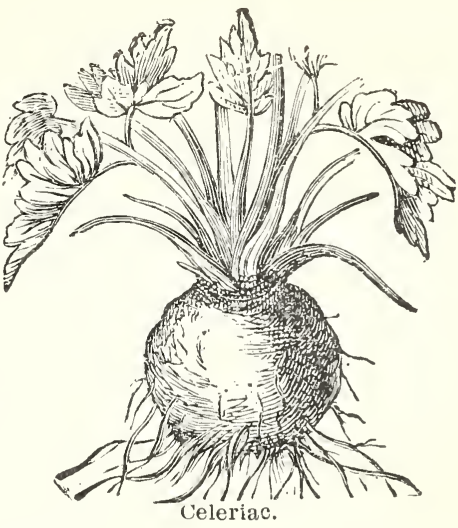

Heart

SWEET CORN-Süffort. BEST VARIETIES FOR FAMILY USE.

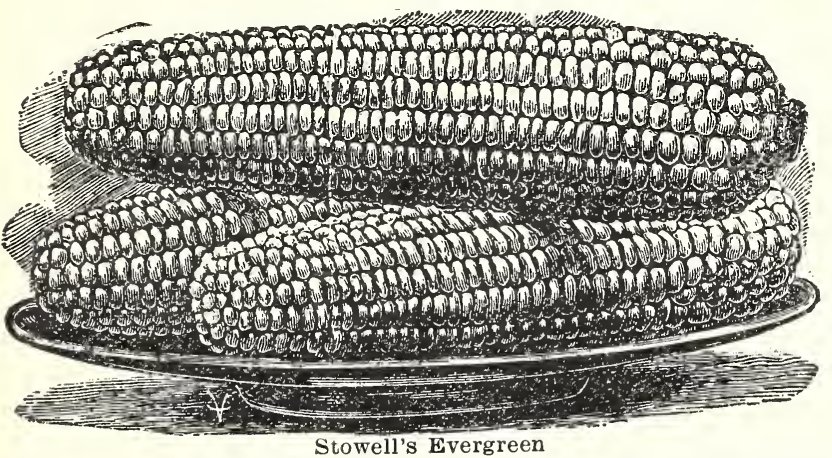

Golden Bantam. For sweetness and richness of flavor it has no equal. It is a hardy, early maturing variety of very dwarf growth and can, therefore, be planted closer than other sorts, the ideal Corn for the home garden. Pkt. 5e, per lb. 25c

Gountry Gentleman. The great merit or thes fine main crop Sweet Corn is its delicious qual. ity, being the sweetest and most tender of all. The ears are medium, cob small, kernels deep; pearly white in color. It is very productive, bearing from two to four ears on the stalk. Ripens about same time as Stowell's Evergreen.

Plat. 5c, per 1b. 250

Stowell's Eversreen. More extensively plan. ted than any other sort, being the general favorite with market gardeners and canners for late use. If planted at the same time with earlier kinds it will keep the table supplied until October. Ears are of good size, grain deep, tender and sugary, remaining a long time in condition for cooking. Plkt. 5e, per lb. 25o

\section{POP CORN}

A Profitable Crop. We have choice seed. It pops large and white.

Pkt. 5o, per 1b. 15c.

\section{CUCUMBER-Brurken.}

This is one of the vegetables that can be grown to perfection by any one who can control a few square yards of soil that is fully exposed to the sun. Every family should be supplied from its own garden, since the fruit is so much better, when rathered fresh from the vines than it is in the more or less wilted condition in which it is found on the market.

Pick the fruit berore it begins to ripen, as the vines will cease setting fruit as soon as any seed begins to mature:

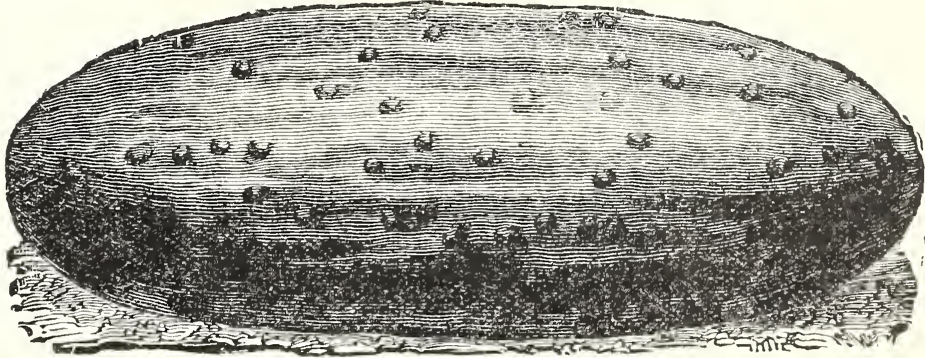

Improved Long Green Cucumber.

LONG GREEN. Fruit from 10 to 12 inches long, dark green, firm and crisp. It is used for slicing, also for sweet pickles. Pkt, 5o, oz. 10c, $1 /$ b. 40.

CHICAGU PICKLE. This is one of the best varieties and largely useo by pickle factories. The fruit is of medium length, pointed at both ends, with large and prominent spin€s; color deep green. Pkt. 5o, oz. 10e, 34.16 .350$. 


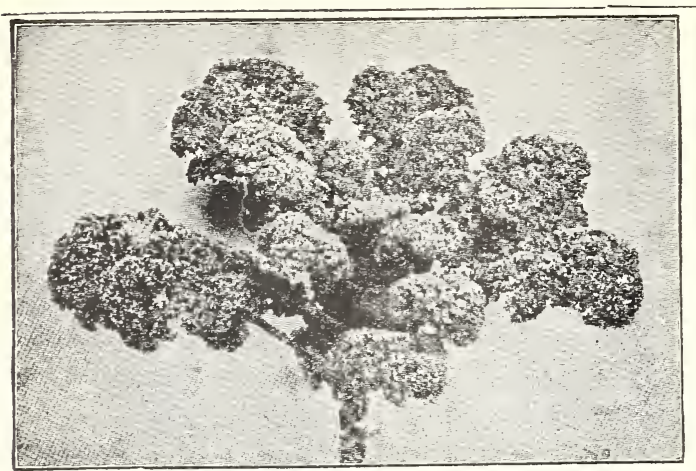

Dwarf German Kale
EGG PLANT-CFier Fflanze.

NEW YORK IMPROVED PURPLE. This varie'ty is a general favorite both for market and private use. Plants, large, spreading; foliage light green; fruit very large, oval: color a splendid dark purple. Plants usually ripen four to eight large fruits. Pkt. 5c.

\section{ENDIVE-Winter=ङalat.}

This plant furnishes an attractive and appetizing salad for the fall and winter months, or by repeated sowing a supply may be had nearly all the year round.

GREEN CURLED. Leaves finely cut or laciniated, giving the plant a rich mossy appearance which is greatly, enhanced when the centers are nicely blanched. Pkt. 5o, oz. 15c, $1 / 4$ lb. 35c.

BROAD.LEA VED BATAVIAN. Has slightly wrinkled thick leaves. It is usually grown for use in soups and stews. Pkt.5c, oz.15c.

BORECOLE, or KALE-ஞ̋rün=গิ๊hl.

The Kales are more hardy than cabbage, and are improved by frost, but the time and manner of sowing and the culture are identical with cabbage.

DWARF GERMAN, or GERMAN GREENS. A dwarf variety, rarely exceeding 18 inches in height, but spreading out under good cultivation to 3 feet in diameter; the leaves are very beautifully curled, and of a bright green. Pkt. 5c, oz. 20c

\section{HERBS-Rrăuter.}

DILL. Leaves used with pickles, seeds for flavoring soups and rinegar. Plkt.5e, oz. 10c, $1 / 4$ lb. 30e

SAGE. Leaves are used in stuffing and sauces. Pkt. 50.

SAVORY, SUMMER. Used for seasoning. Pkt.5c.

THYME. For seasoning. Pkt. 5 c.

LAVENDER. Its flowers are used in the manufacture of oil and distilled water. Pkt. 5.

MARJORAM, Sweet. Used for seasoning. Pkt. 5o

WORMWOOD. Beneflcial for poultry. Pkt.5c.

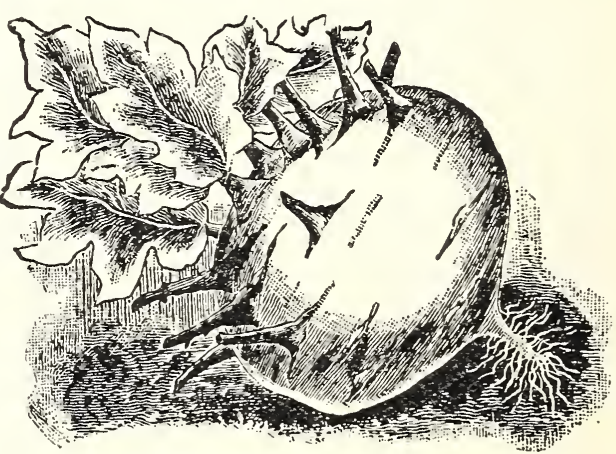

Early White Vienna Kohlrabi.

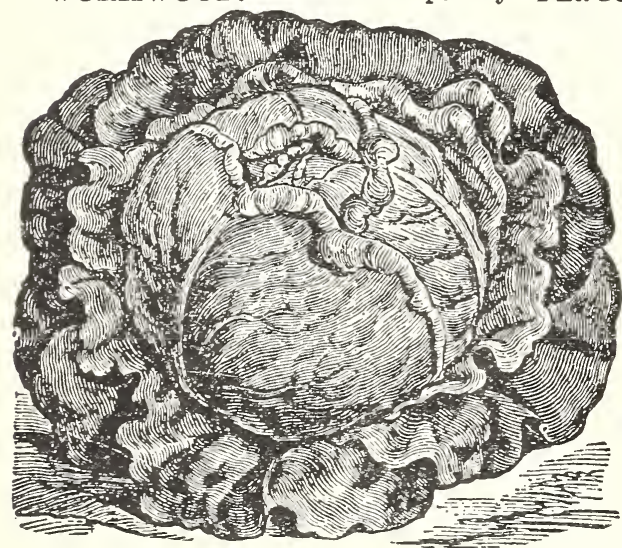

Big Boston Head Lettuce.

KOHL-RABI or Turnip=Rooted Cabbage- - Tohlrabi.

A vegetable of the cabbage tribe, with a thick stem; sweet and deli. cate when cooked.

EARLY WHITE VIBNNA. Flesh is white. Pkt. 5o.

EARLY PURPLE VIENNA. Rich purple. Pkt. 5c.

\section{LETTUCE-Ŝpf= Salat.}

CABBAGE OR HEADING VARIETIES.

B I G BOS TON. The most popular and satisfactory head let. tuce with market gardeners. It forms a fine head, is tender and crisp, and is very slow to run to seed. Outer leaves are light green, and the inner ones are bright, creamy yellow, of a very fine flavor. Altogether, we recommend it as being the best head lettuce for general use.

Pkt. 5c, oz. 15o, $3 / 4$ lb. 35c

IMPROVED HANSON. For outdoor culture there are none more reliable than this. In rich ground, well cultivated, the heads grow to resemble small cabbages. Outer leaves green, white within, having no bitter taste. Pkt. 5c, oz. 15c, 1/4 lb. 35c。

\section{LETTUCE-Blätter=Salat́.}

BLACK-SEEDED SIMPSON. Among the many varieties of Curled or Leaf Lettuce, there is no one better fltted for the general use of market gardeners and the private cultivator than Black-Seeded Simpson. It is suitable for growing under glass as well as for early outdoor planting. Forms a compact mass of thin leaves which are tender and of excellent quality. By far the most popular Lettuce with the market gardeners of Chicago and elsewhere. Pkt. 5c, oz. 15c, 3/ lb. 30c

PRIZE HEAD. For general use no Lettuce has ever given such universal satisfaction. It forms a large head of loose leaves, bright green in color, tinged at the edges with red; very crisp and tender, and of excellent flavor, and has the faculty of keeping its good qualities throughout the entire season.

Pkt. 5c, oz. 15c, 3/4 lb. 30e

COS LETTUCE, Trianon. These Let tuce make long, narrow, upright heads; sweet and tender. 


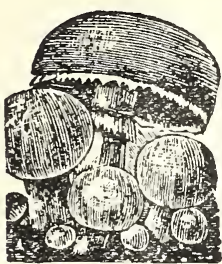

\section{MUSHROOM SPAWN}

\section{Champigost gint}

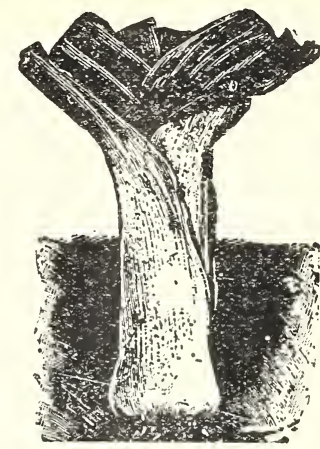

London Flag Leek

\section{Mushroom Culture in Brief.}

Two or three weeks before the bed is to be made, collect a quantity of horse manure, free from straw, and mix an equal amount loam from an old pasture with it. Place it under cover, turning it over once or twice a week until the fiery heat has been exhausted.

When the manure is in condition to be made up, lay out the bed, say three feet wide, ten feet long, and make the bed in layers of about one foot deep; press it down firmly as the process of building goes on. When the bed has been made some time, say a week or thereabouts, and the heat is sufficiently declined to a temperature of about 65 or 75 degrees, the spawn may be put into it. Break the spawn in pieces two inches square, and pnt them six inches apart, all over the bed, then cover the bed with two inches of rich soil, not too wet or overdry. Cover the bed with a foot of dried straw or hay; examine once a week to see if the manure is not heated while in this condition; if so, it will destroy the spawn, and necessitate spawning a second time. If everything goes on well, you may expect Mushrooms in about five or six weeks. It comes in bricks weighing about twenty ounces each. One brick will spawn about eight square feet of bed. Prices per briok 25 c

\section{MUSTARD-Senie.}

The young leaves are used in early spring with cress, let. tuce, etc. Sow thickly in shallow drills a foot apart, and cut when a few inches high. May also be boiled and eaten Hue spinach.

WHITE. Excellent for salads or garnishing. Pkt, 5 o.

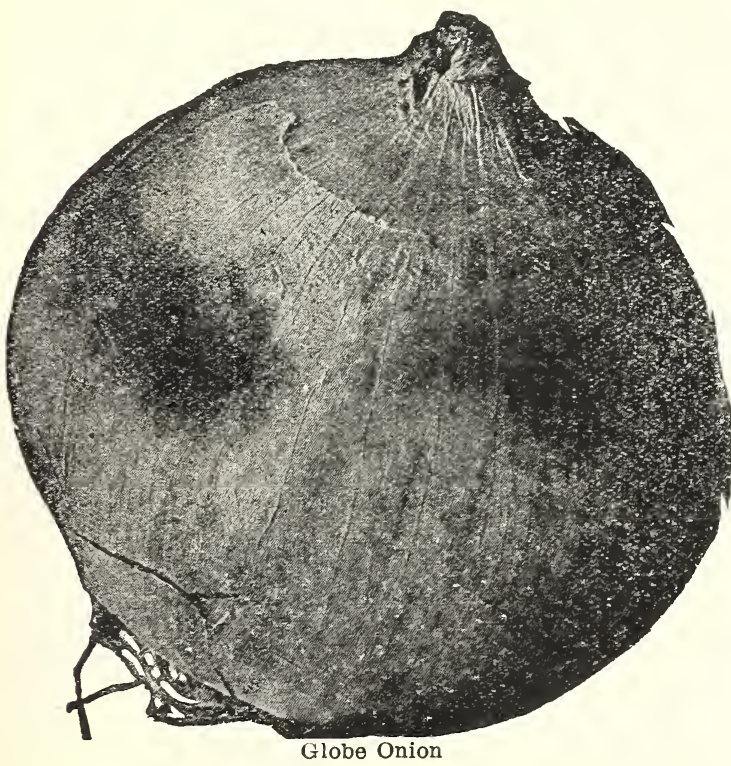

LEEKS-2aud) .

LONDON FLAG. Hardy: of good quality; the whole plant is edible. Pkt. 5c, oz. 20c.

MONSTROUS CARENTAN, Grows rapidly and is very hardy. The edible stem is 6 to 8 inches long and 3 inches in diameter. Plkt.50,0z.200.

\section{WATER MELON-Bafiermelonen.}

COLE'S EARLY is the finest watermelon for the fam. ily garden, especially in our Northern States. Fruits grow to a medium size, with a large heart and bright-red flesh of delicate texture. It has a very thin rind which makes it. deficient in shipping qualities. Extreme earliness is its grea merit. It will ripen in Northern States where other melons would be a failure. Pkt. 5c, oz. 100, 3/ 1b. 200.

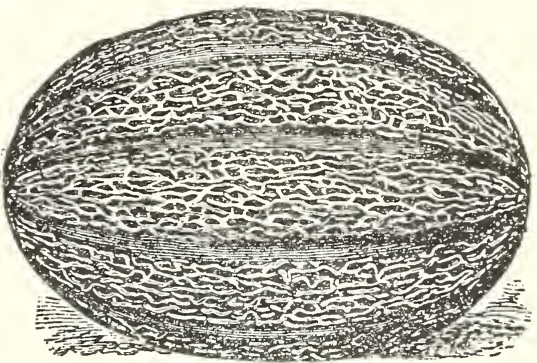

Rocky Ford Musk Melon

MUSK MELON-3u der=Melonen.

ROCKY FORD. Nearly every leading hotel and restaurant in America uses large quantities of this famous melon which is just the right size to serve in halves. The ripe melons are beautifully netted and ribbed. Solid green flesh, sweet and melting. Plkt. 5o, oz. 10o, 1/4 1b. 30o.

PAUL ROSE. A cross of the Osage and Netted Gem; about ten days earlier than the former. Fruit oval, with very small seed cavity. Red fleshed. A good shipper, espe cially in baskets. Pkt. 5e, oz. 10c, $1 / 4$ lb. 30c.

OSAGE or MILLER'S CREAM. The fruit is medium-sized, oval, somewhat resembling a cocoanut. Skin, dark green, slightly netted and of a rich orange color wher the melon lies on the ground. The flesh is thick, salmon colored, and in quality is hard to beat. Plat. 5e, oz. 10o 1/4 lb. 35c.

\section{OKRA-Drra.}

Sow after weather becomes warm, in rows three feet apart two feet apart in the rows. Will succeed in any good garden soil. The young green pods make a healthful and nutritious soup, and when pickled are a fine salad.

IMPROVED DWARF. A distinct early variety. Pods comparatively short. Pkt. 5e, oz. 10s.

\section{ONION SEED-3wicbert.}

YELLOW GLOBE DANVERS. Globe shaped of medium size the skin is a beautiful silvery yellow color. Comparatively mild and well flavored. The standard yellow onion for Markot. Pkt. 5c, oz :30c, $1 / 4$ ib. 80c.

WHITE GLOBE. One of the most beautiful globular mild flavored onions. A favorite for market; salable every. where. Is of very large size, and of fine quality. Pkt. $5 \mathrm{c} ;$ oz, 40c, $1 / 4 \mathrm{lb}$. $\$ 1.25$.

LARGE RED GLOBE. Of medium size; spherical witb small neck. One of the most handsome onions in cultivation It is a splendid keeper and an onion that no one will err in planting. Pkt. 5e; oz. 30c, $1 / 4$ lb. S0c.

\section{ONION SETS-Bwicbel= Ectblinge.}

Bottom Onion Sets produce Onion bulbs much earlier than can be done by sowing the seed and allows the planter the early high market prices and permits the sowing of another crop on the land the same year. For green or bunch Onion sets produce a crop in half the time it takes to raise these from seed.

are subject to market changes which vary from day to dag. Latest values on request. 


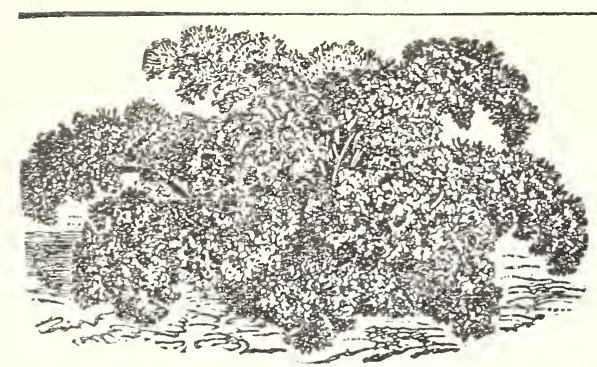

Champion Moss Curled Parsley oz. 10c, 34 1b. 30c. HAMBURG ROOTED or GERMAN PARSLEY. The root resembles a small
parsnip and is the edible part of this sort; extensively used for flavoring soups. HAMBURG ROOTED or GERMAN PARSLEY. The root resem
parsnip and is the edible part of this sort; extensively used for flavoring soups. Pkt. 5c, oz. 10c, 34 lb. 30c.

\section{CIIA}

This is a fine prize winning Englis variety, entirely distinct. It is a very quick, robust sor', making remarkably handsome, compact planis, which have leaves so crumpled and curled as to give making it the very best parsley for garnishing. Its flavor is exceedingly pleasant and aromatic, so that for flavoring sauces, dressings, etc., it is unsurpassed.

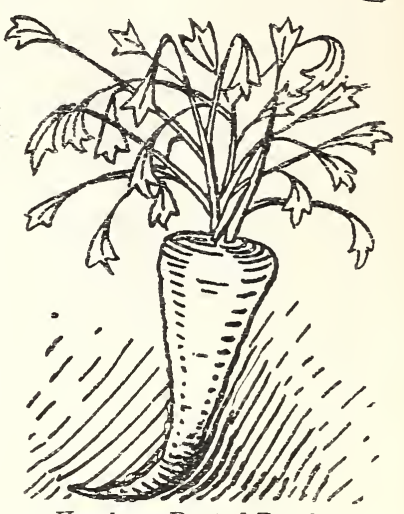

Hamburg Rooted Parsley

\section{PEPPER- Ffeffer.}

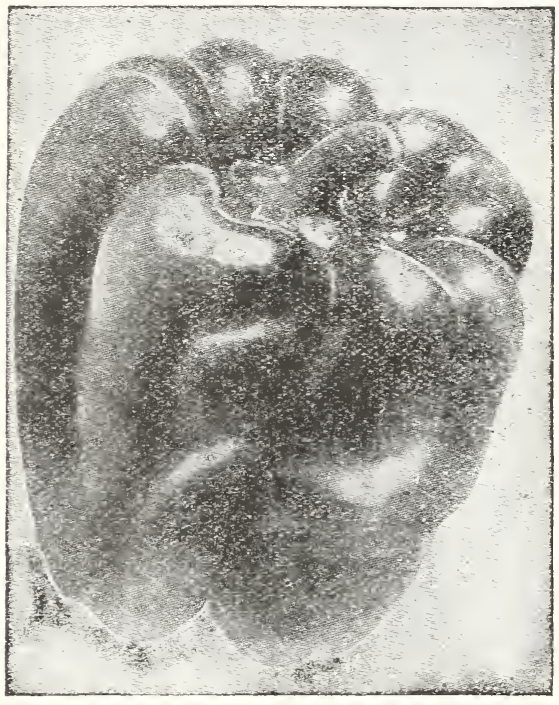

CHINESE GIANT PEPPER

PEPPER PLANTS. These we can supply in season. Should be set out after all danger of frost is over.

GARDEN PEAS- Erbjen.

\section{THREE BEST PEAS FOR TABLE USE.}

AMERICAN WONDER. Vigorous, productive vines with a luxuriant foliage, and producing the leaves on one side of the stalk, and growing from 9 to 12 inches high. On account of its dwarf habit of growth it is very desirable for private garden use. Pods are light colored, straight, round, about $2 \frac{1}{2}$ inches long, and blunt at the end. Fit for picking 55 days from planting. Seed is wrinkled, green, medium in size and square at the ends. Per 1b. 30c.

NOTT'S EXCELSIOR. One of the most valuable of Peas. Surpassing in earliness, yield and quality. This is usually ready for the table in 40 to 45 days from planting. It grows about 14 inches high. Of vigorous constitution and wonderfully productive. Lbo $\mathbf{3 0 s}$.

DWARF TELEPIIONE. Vines, 18 to 20 inches high, with rather coarse foliage, medium light green, bearing pods, broad, straight, and about 4 inches long. Pale green in color and well-filled with peas of excellent flavor. Ready for picking from 62 to 65 days from planting. Seed, pale green: large, much wrinkled. Per lb. 30c.

\section{PARSNIP- Bajtinafen.} IMPROVED GUERNSEl. This is a good, half-long variety, having
smooth rootss. It is of good quality and recommended for the family garden. Pkt. 5e, ox. 15e, 1/1 1h. 50r.

\section{PEANUTS.}

These can be easily grown and a supply on hand will afford much satisfaction to the younger members of the family.

SELECTED VIRGINIA. A tine, productive strain, selected especially for seed purposes. Lb. 300.
CHINESE GIANT. The best, mildest and largest roo eating and for stuffing. Pkt. 10c.

NOCERA. Sweetest and mildest of all peppers. Can be picked plant and eaten as one would eat an apple. It is an early fruit. ing variety and an abundant yielder. The plants make a very hand-

PIMIENTO. The sweetest Pepper grown, does not contres the slants are exof a shape which is desirable for filling. It may also be used in preparing salads and for flavoring. The flesh is quite thick and the Pepper may be scalded for peeling the skin off. When fully ripe the Peppers are of brilliant pleasant flaror. Pkt. 5e.

\section{PUMPKIN-ת̈̈rbi:}

Pumpar pIe PuMPr. One of the very best of all flesh solid and fine grained. cavity is small. A splendid keeper. Pkt. 5e, oz, 10c, $\mathbf{2}$ oz.

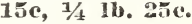

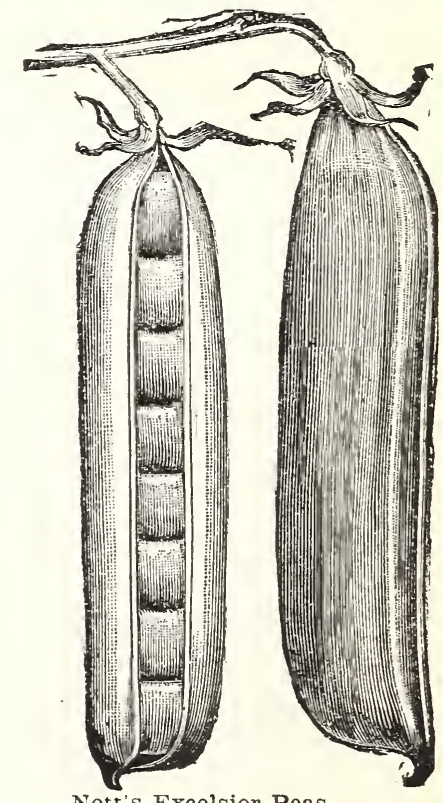

Nott's Excelsior Peas. 


\section{VEGETABLE SEEDS}

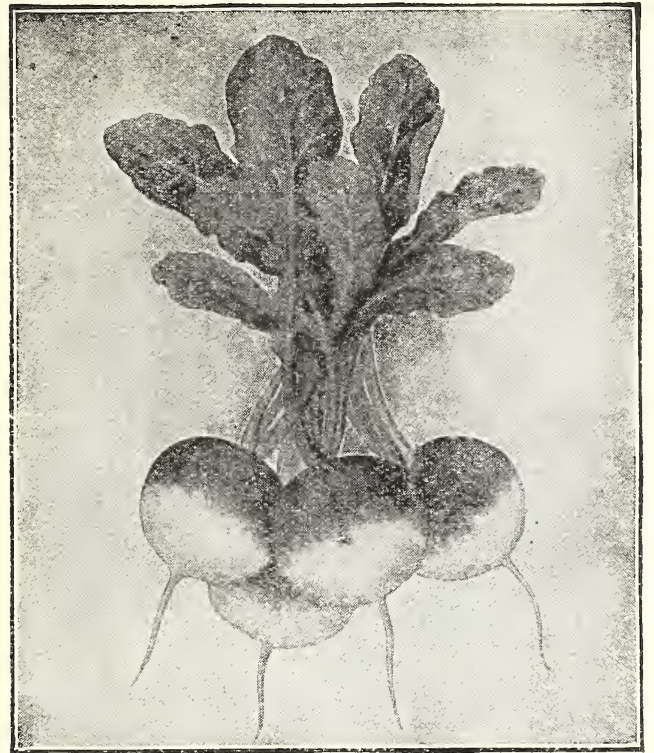

White Tipped Radish.

RHUBARB ROOTS- Rhabarber.

LINNA EUS. The earliest variety grown. Desirable for market or family garden. Extra large clumps. Each 25c.

SORREL-Sauerampfer.

Of the easiest growth. Sorrel is cultivated for its leaves, which possess a very fine flavor; boiled and served like Sinach. It also makes a delicious soup. Pkt. 5c, oz. 206.

\section{SPINACH-Spinat.}

THICK LEAVED ROUND. One of the best marlset sorts for spring or autumn sowing. Oz, 10c, $34 \mathbf{1 b}$. 15r. 1b. 50c.

VICTORIA. This variety is an acquisition to the list of Spinach; it matures later but is of remarkably fine texture, of the deepest green. heavily crimped thick, lleshy leaves, deep red stem. It is now grown extensively by the truckers of our markets. Pkt. 5c, oz. 10c, 1/4 1b. 15c.

$$
\text { SQUASH }
$$

GIANT SUMMER CROOKNECK. Twice as large as the ordinary Summer Crookneck, much more warty and several days earlier. Fruit, golden yellow. Plt. 5c, oz, 10c.

GOLDEN CUSTARD. It grows in bush form. Color, rich golden yellow. A valuable variety of superior quality. Pkt. 5c, oz. 10c.

BOSTON MARROW. Early fall sort; rich orange color, excellent flavor. Pkt. 5e, oz. 10c.

HUBBARD. The favorite winter squash Color, dark green; shell, extremely hard; excellent keeper Pkt.5c,

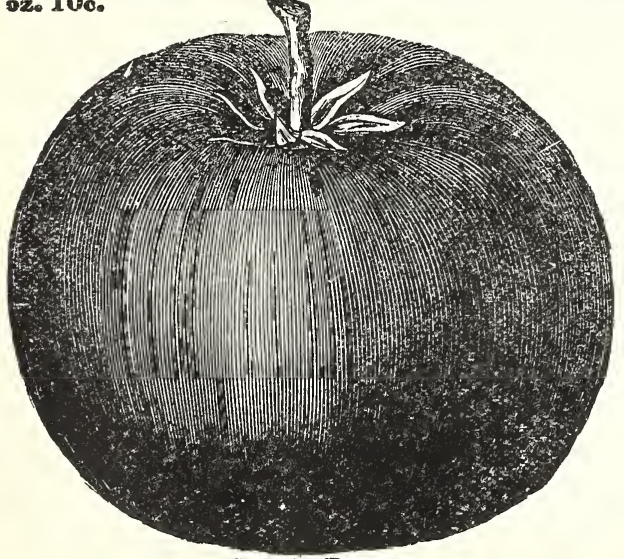

Beauty Tomato

\section{SEED POTATOES}

Choice Stock Grown Expressly for Seed Purposes.

RED RIVER EARLY OHIO. Probably the most popular early potato in the country. 'Iubers smooth, oblong in shape; resisting scab and dry weather well and bearing the even-sized, abundant tubers compactly in the hill. A popular favorite.

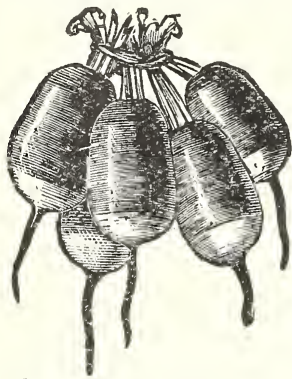

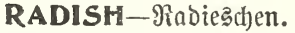

Pkt. 5c, oz. 15c, 1/4 1b. 40, ib. $\$ 1.25$.

FRENCH BREAKFAST.

Fine for open ground or forcing. Valued for its excellent quality and fine color, which is a beautiful scar. let on the body and white at the extremity. Flesh, white, tender and mild.

Frenchbreakfast Radish

SCARLET TURNIP WHITE TIPPED. With Chicago gardeners this is by far the most popular early Radish or for planting in succession. Tops and roots are small, skin bright scarlet, shaded to white at the tip; flesh, white, mild and crisp. We have an excellent strain of seed.

FARLY SCATLET GLOIBE. A desirable sort for hotbed forcing and outdoors; very early; flavor, mild, crisp, juicy and tender; top small; will stand heat without becoming pithy. One of the best selling and most attractive radishes, on account of its bright scarlet color and handsome shape. Is ready in twenty. eight days.

WIITE STRASBURG, One of the best of the later sorts, of handsome oblong shape, tapering to a point. Both skin and flesh are pure white.

WVHI'TE ICICLL: A long Radish, transparent white, small top, allowing close planting, and are very crisp and brittle. The Radishes remain in good condition for a long time while growing.

LONG BLACI SPANISH. Black skin. Flesh white, excellent flavor. One of the hardiest and finest.

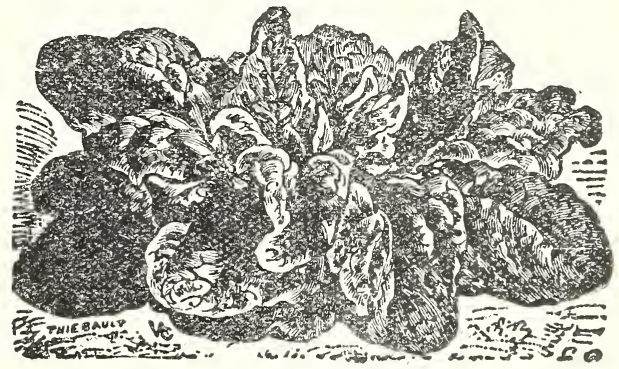

Victoria Spinach.

TOMATO-- Liebegapfel.

IMPROVED BEAUTY. A favorite both for the home market or shipping purposes. Medium early. Fruit round, smooth. crimson, with purplish tinge. Plat.50,0z.30c.

JUNE PIN. The earliest of the pink tomatoes and one of the very best for the family garden. The skin is thin, very smooth; flesh solid, of excellent quality aud flavor.

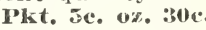

DWARF CHAMPION. Dwarf and compact in growth, the plants grow stiff and upright, with foliage unlike most others. Fruit in form and color like Acme. Recommended for the home garden Pkt. 5c, oz. 35c.

YELLOW PLUM. A small yellow variety, of handsome appearance and fair quality. Pkt. 5c,

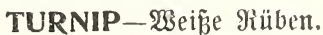

PURPLE TOP WHITE GLOHBE. A fine table turnip. It is an early and heavy cropper as well as a good keeper. The bulb is a very handsome globe, and is especially in demand among market gardeners. Pkt. 5c, oz. 10e, 1/4 Ib. 30c.

SKIRVING'S PURPLE TOP. Fiesh yellow. Good køepes Pkt. 5o, oz. 15e, $1 / 4 \mathrm{lb}, 35 \mathrm{c}$. 


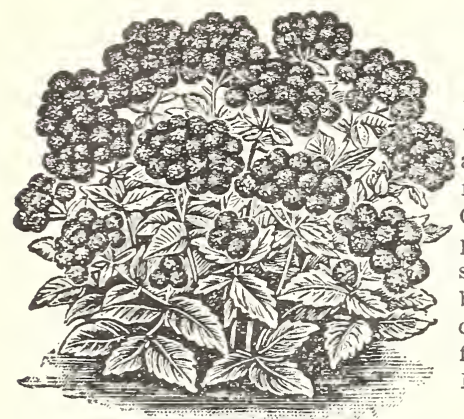

AGERATUM.

Plants that grow well anywbere. The tall-growing varieties are effective whe:I mingled with Alyssum, Candy tuft and similar plants. The dwarf sorts make excellen borders. They bear clusters of feathery flowery all season Dwarf blue. Pkt 10c.

Ageratum

Amiratés Caudias.

LOVE-LIES-BLEEDING. Of rapid growth, easy culture, and ornamental, when grown among other plants. Tricoior (Joseph's Coat). Pkt.100.

ANTIRRHINUI (Snapdragon).

A border plant having dark, glossy leaves, and curiously shaped, showy colored flowers with spotted throats. Our list embraces the best of the giant-flowered, improved strains. Th sugh perennial. they blossom the first year, if seed is sown early. Slightly covered with leaves, they withstand our winters. Dwarf Mixed, $10 c$.

\section{ASTERS.}

It is unnecessary to dwell on the great beauty of these popular favorites, as they are appreciated by every one. Asters are annuals, and they are sufficiently hardy to endure a little frost without injury.

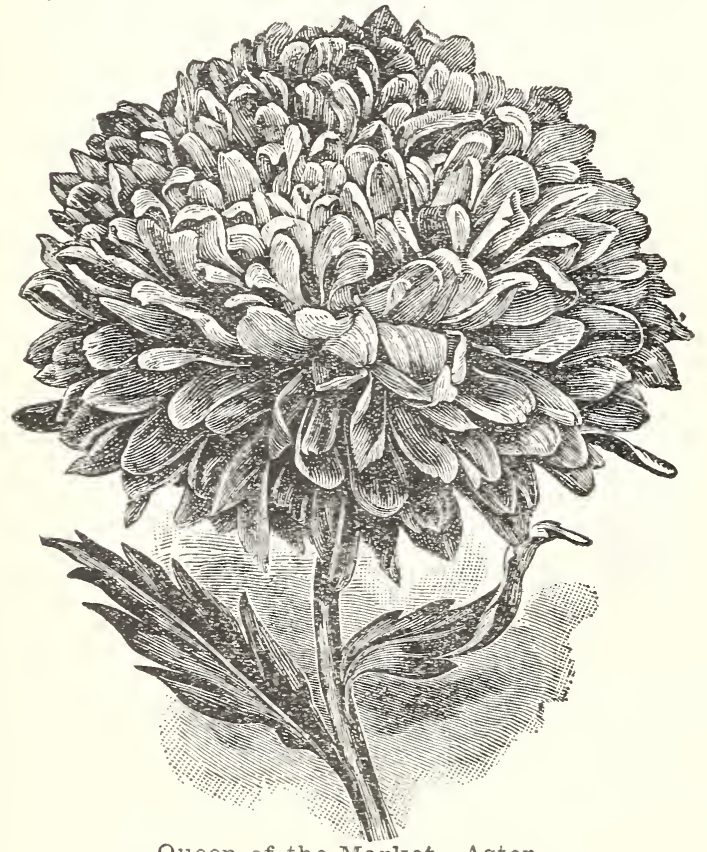

Queen of the Market-Aster.

Below we sive a few general cultural directions: more complete details are printed upon most of our packets.

SEED SOWING AND PLANT RAISING.

A general rule for the seed bed is to have the soil rich, level and worked very finely. Sow the seed evenly in the rows, cover with the finest of soil, about three times the diameter of the seed, and press the soil firmly over the seed. The soil should never become dry after the seeds have swelled for if it does, they will be almost certain to fail. For this reason it is best to sow small seeds in shallow boxes, 2 to 3 inches in depth and of any convenient size, that the surface of the soil may be kept properly moistened.
TRANSPLANTING.

After the seeds are up, care must be taken to give them plenty of air and moisture, and yet not too much water, or they. will "damp off" (rot at the top of the ground). As soon as the second leaves are well out, they should be transplanted into pots or new boxes. When finally transplanted to the bed or border, they should be watered frequently until well established.

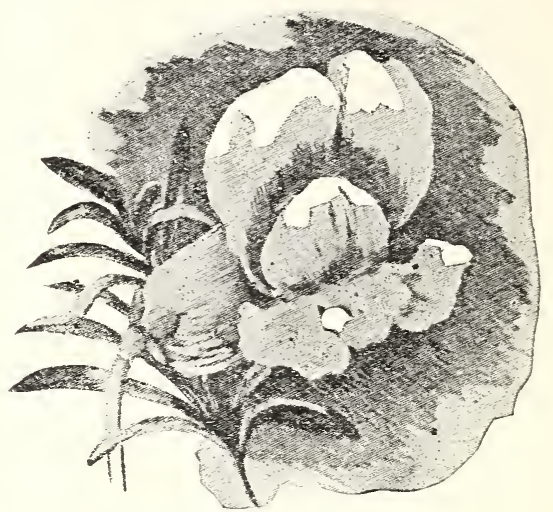

Antirrhinum-Snapdragon.

ASTER. American Beauty. A most distinct and valuable variety. Is is similar in type of flower and growth to the well-known Late Branching Asters, but differs in that all the large blossoms are produced on much longer and heavier stems. The flowers are fully double to the last, and are a most lovely shade of bright carmine-rose, almost identical with the Famous American Beauty Rose White, Pink, Crimson, Lavender, Purple and Mixed. Pkt. 15c.

GIANT CONET ASTER. This fine Aster has wor numerous commendations from the leading horticultural societies, and is one of the best introductions of recent years. It is of pyramidal habit, 2 to $2 \frac{1}{2}$ feet high. Flowers beautifully curled and twisted, 4 to 6 inches across; pure white with a quilled yellow center. White, Pink, Purple, Crimson, Lavender, and Mixed Colors. Per Pkt. 10e.

QUEEV OF' THE MARKET. Blooms three weeks earlier than the other Asters, and therefore a favorite with florists. Beautiful flowers of large size and fine appearance, borne on stiff stems. White, Pink, Crimson, Purple, and Mixed. Pkt. $10 \%$.

MIKADO. This aster blooms in August, rather dwarf in growth, branching habit and a profuse bloomer. The petals are narrow, very long and gracefully reflexed; the outer petals show to their full extent, while gradually toward the center they bend and curl on each other in such magnificent disorder as to make it the fluffiest and most desirable aster.

Pink, White, Lavender and Mixed. Pkt. $10 c$.

VICK'S BRANCHING. They bloom in August and September. The flowers are of extraordinary sizemuch larger than other varieties-and stand erect on long, graceful stems, well above the foliage; flower stems 15 to 20 inches long. Vick's White, Vick's Mixed. Pkt. 10c.

CRIMSON GIANT. A splendid upright-growing sort, producing very large, well-formed dark, crimson flowers. Its brilliancy of color and erect habit make it desirable for garden culture. Pkt. 15c.

CREGO. The form of the flower is similar to that of the Comet class, but much larger. They are fluffy and graceful. In bloom from mid-August until fall. This Aster is a universal favorite both with florists and rrivate gardeners. Mixed. Per Pkt. 10c.

HEART OF FRANCE. The best red Aster ever introduced. The petals are of velvaty texture and a warm glowing color which is retained to the end. Per Pkt. 10c.

MIXTURE OF ASTERS. Made of the best varieties suitable for cut flower purposes, principally of white, pink and the brightest red, together with a small proportion of blue and purple. Hest named varietios. Mixed, Pkt. 10c. 


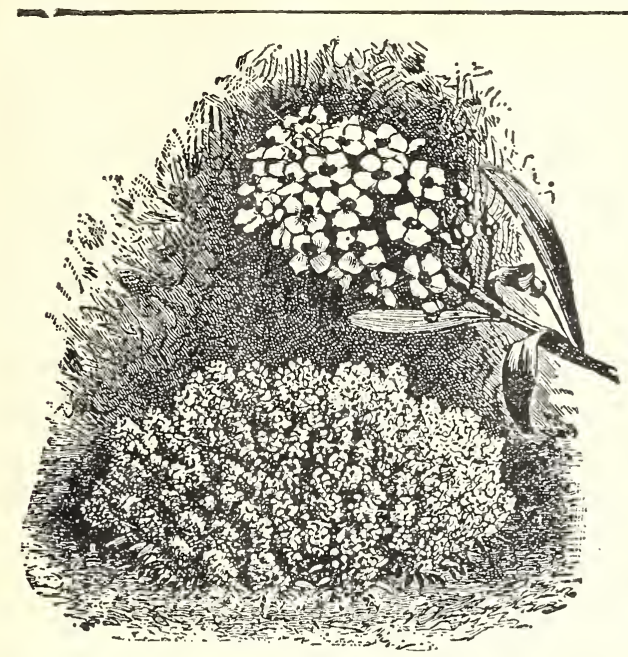

Alyssum-Little Gem.

SWEET ALYSSUM.

Used chiefly for edging beds, and in window boxes. Its fragrant white flowers are prized for bouquets. The blossoms are produced all summer. Six inches. Pkt. 10c.

ALYSSUM SWEET, LITTLE GEM. Of dense growth and very dwarf-four inches. Pure white flowers, fine for edgings. Pkt.10c.

\section{AQUILEGIA (Columbine).}

Well-known and favorite plants for the garden border; especially suitable for shady places. Are easily grown from seed, and soon form large clumps. Flowers are beautiful, and produce profusely in May and June 1 to $2 \mathrm{ft}$. H. P. Double, mixed colors. Pkt.10c.

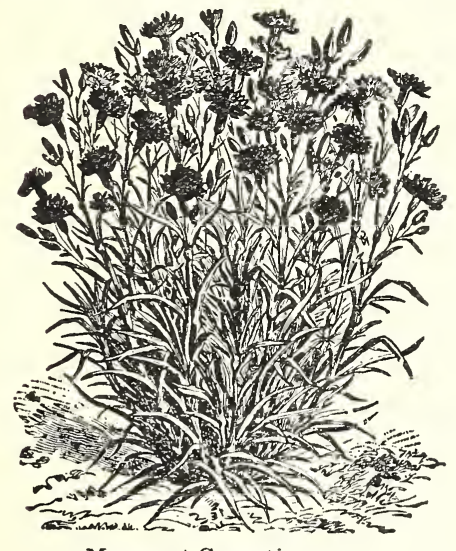

Margaret Carnation

\section{CARNATION PINKS.}

MARGARET CARNATIONS. Begin flowering in a fow weeks from time of sowing. They produce on long stems an abundance of large beautifully fringed fragrant flowers, white, crimson, striped, etc. Marǵaret, mixed colors. Pkt. 10 c

BARNARD'S CARNATION MIXTURE. Contains seeds of all Carnations which bloom the first season after sowing. A packet, sufficient for a large bed. Immense double flowers. Pkt. 10c.

\section{FANTERBURY BELLS.}

CUP AND SAUCER. The flowers differ from the ordinary type in having an extra large calyz of the same color of the flower, giving the appeamnce of a cup and ancer. In bloom for weeks during early summer. Mixed. 10c.

CALliopsis (Also called Coreopsis).

Showy, beautiful, free-blooming plants, producing large bright flowers of rich and charming colors throughout the entire summer. Mainly hardy annuals. 1 to 2 feet. Best Mixed. Pkt. 10c. when two or three inches in height.

\section{CARDINAL CLIMBER}

thrilliant and distinct elimber introduced for many ing habit; flowers all summer, cardinal-reã clusters, 15 feet. Pkt. 10c.

\section{BALLOON VINE.}

BEAN, SCARLET RUNNER.

CALENDULA (Pot Marigold).

als that thrive anywhere, especially in city gardens.

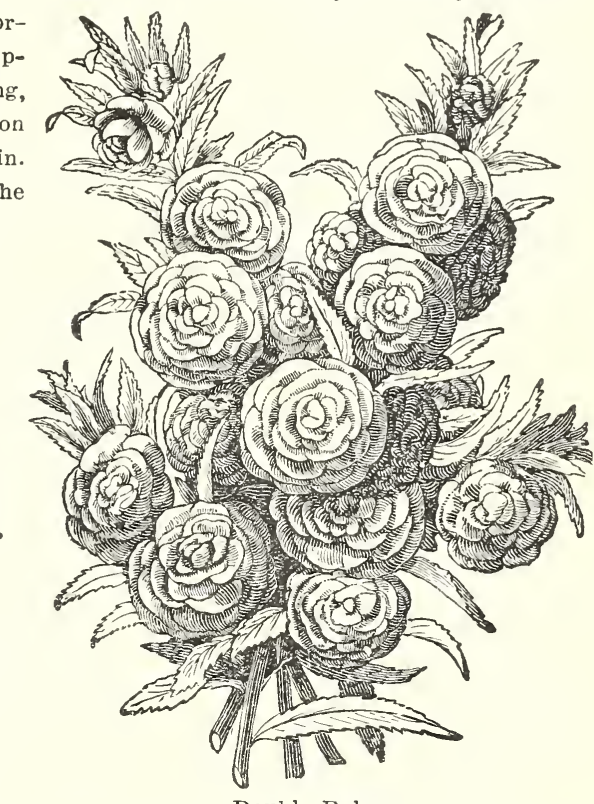

Double Balsam.

BALSAM OR LADY SLIPPARS. The Balsam is a native of India loves rich soil, hot sun, and plenty of water. Sow the seed in window boxes or hotbeds early or in the open air in May and trans. the leaves as shown in the illustration. Double mixed colors.

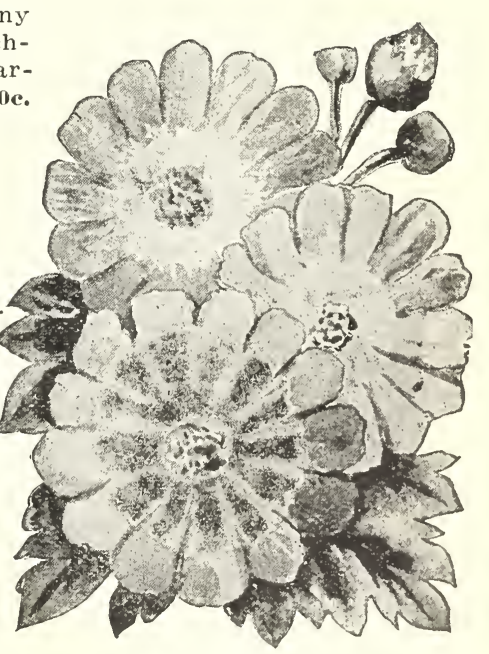

Calliopsis. 


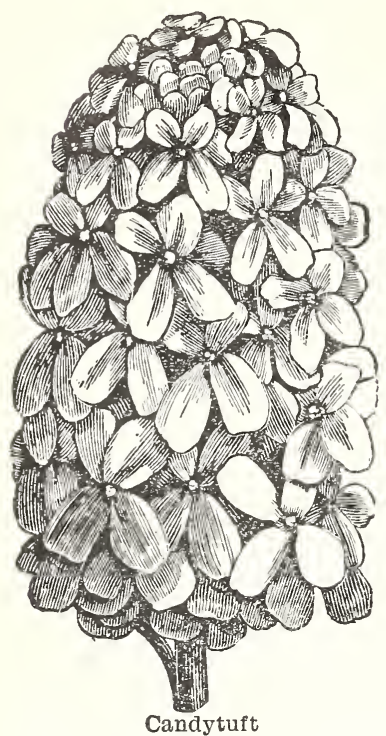

CANDYTUFT.

A dwarf annual of the easiest culture; free-blooming, showy and useful for beds, borders and edgings. Sow seeds where plants are to bloom, in rows 6 or 8 in. apart, thinning out to afford plenty of room, as they branch quite freely. Height, 1 foot. Mixed. Pkt. 10o.

Giant Hyacinth Flowered Candytuft. Bears bold, snow-white flowers, especially if the seedings are transplanted and allowed to spread. Plants branch freely, making them desirable for filling borders. Splendid cut flowers. Pkt. 10c.

\section{Plumed Cockscomb.}

Ostrich Foather. Grows in pyramid form. Its flower sprays resemble plumes. They are orange and scarlet in color. Mixed. Pkt.10c.

Dwarf mixed. Extra large combs. Pkt. 10o.

\section{COSMOS.}

Plants 4 to 6 feet high, with delicate, feathery foliage. The pretty flowers produced from September until fall, are of shades of rose, red and also pure white. Excellent for cutting. Seed sown outside in May will flower by September. Early Flowering, Mixed. Pkt.10c.

\section{CYPRESS VINE.}

A handsome climber that will run 15 feet $01^{\circ}$ more during the season. Should be planted by the side of a trellis, tree or stakes. [ts beautifu] dark-green foliage and star-shaped flowers in clusters are a mass of beauty all summer long. Pkt. 10e.

\section{ANNUAL CHRYSANTHEMUMS}

Summer blooming border plants of compact, thrifty growth. 1 to $11 / 2 \mathrm{ft}$. high, producing large blooms 2 inches across, from July until frost. Extensively grown for cut flowers. They are partial to a little shade. Sow seed in the open where plants are to stand.

Double, Mixed. 'This mixture contains all the most desirable colors. from white to deep orange. Pkt. 100,

\section{HYBRID COLEUS}

Foliage plants of much beauty. Easily grown from seed. They are popular for bedding and pot culture. Seeds sown early in the spring will produce fine plants for outdoor planting. Mixed. Pkt. 10c.

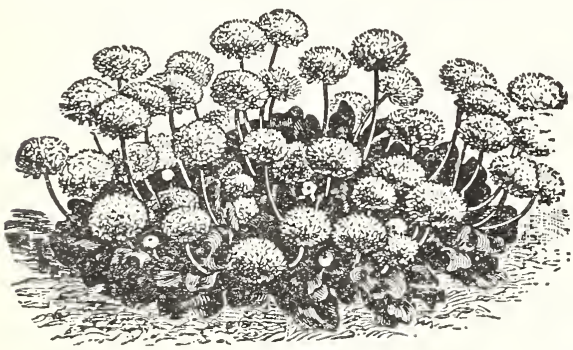

\section{SILVER-LEAVED CENTAUREAS or "DUSTY MILLERS"}

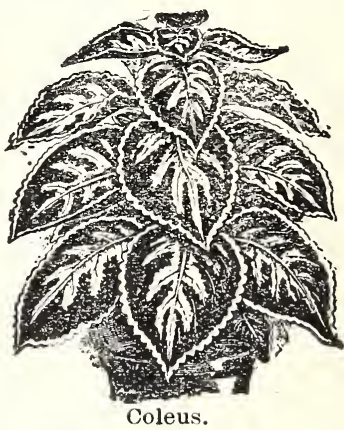

These are planted for bedding or borders, not for flowers Pkt. 100.

\section{COBAEA SCANDENS.}

Magnificent, rapid-growing annual climber with large bell. shaped purple flowers, adapted for outdoor growth in summer. also for the house and greenhouse. A thrifty plant will of ter grow 20 to 30 feet in one season. The flat seeds should be plan ted edge down to insure germination. Give very little water at first. Cobaea Scandens. Purple. Pkt. 10o.

Double Daisies

DIANTHUS or PINKS.

A magnificent genus, embracing some of the most popular flowers in cultivation, producing a grea variety of brilliant colors and profusion of bloom. The hardy biennials, or Chinese and Japanese varie ties, bloom the first season, the same as hardy annuals; height, 1 foot. The hardy perennial varieties are

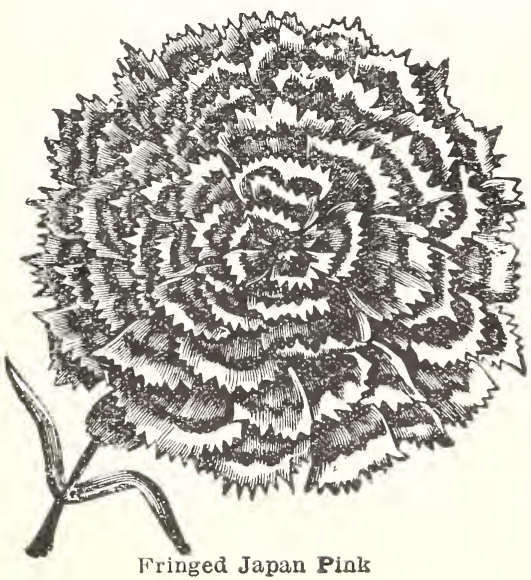
very fragrant and of easy culture for the garden or greenhouse.

Double Annual Pinks. All these varieties bloom profusel and make splendid cut flowers for bouquets, having stout, strong stems. Double, Mixed. Pkt. 100.

\section{DOUBLE DAISY (Bellis Perennis)}

Hardy biennial; usually sown in July or August and transplanted in fall. Early sown seed will bring flowers in autumn. Double, Mixed. Pkt. 10c.

\section{ESCHSCHOLTZIA.}

\section{(California Poppy)}

A useful annual, especially valuable for growing in flower beds and masses. Sow where plants are to bloom. Bright, showy flowers and feathery foliage. Valuable for cut flowers. The yellow varieties make a fine combination when placed with blue flowers-Larkspur, Corn Flowersin a bouquet. Mixed. Pkt. $10 c$.

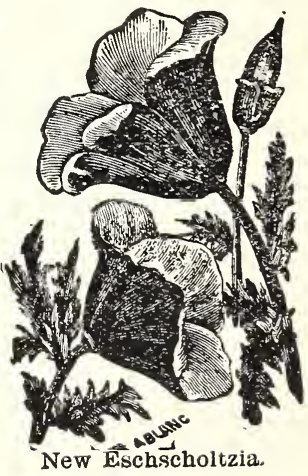




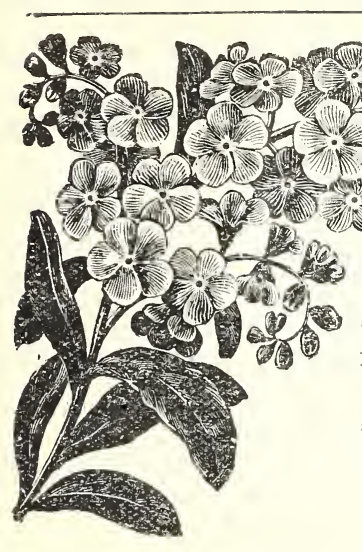

All the varieties are favorites. They like cool, moist soils. Useful for edgings and borders.

Victoria. Sky-blue; dwarf; globular. Phe. 10c. These bear both single and double flowers in scar-
let, yellow, blended and shaded, all summer long. Excellent cutting, Double, Mixed. A. Pkt. 10c.

\section{HELIOTROPE.}

Deliciously fragrant plants, which, if sown early in heat, bloom the first season. 'They are favorite plants for pot culture in winter, or bedded out in

\section{ICE PLANT.}

A singular looking, tender annual, with thick fleshy leaves that have the appearance of being covered with crystals of ice. Pkt. 10o.

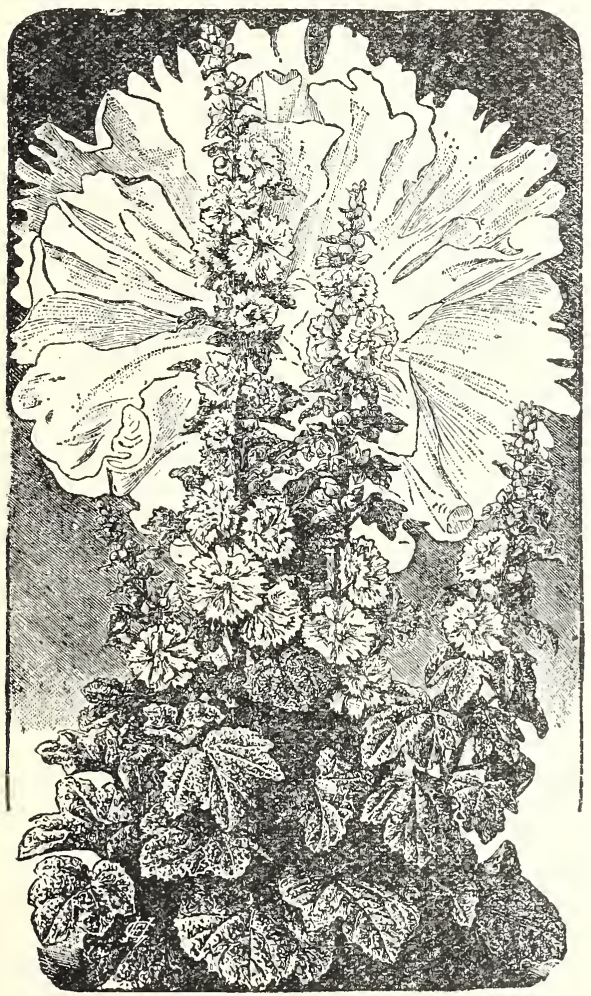

Hollyhocks

\section{HOLL THOCLS.}

They require a dry, deep, rich soil to successfully stand our winters; wet heavy soils are sure death to them. 6 feet.

Mammoth Allegheney. Double and semi-double fringed flowers. Pkt. 10 c.

Doublo Hollyhocks. Choice Double Mixed. Plet. 10c.

\section{GAILLARDIA (Blanket Flower)}

summer. Purple, lilac and white flowers are borne in large trusses. Dark Sorts, mixed. Pkt. 100.

\section{HYACINTH BEAN.}

A fine climber with elusters of purple or white flowers followed by ornamental seed pods. Tender annual; growing from 10 to 20 feet high. Mixed. Oz. 15c, Pkt. 10c.

ORNAMENTAL GOURDS.

Handsome climbers of rapid growth. Very useful for covering fences and other unsightly places, producing fruit of peculiar and various forms which, if allowed to ripen on the vines, can be kept for months as curiosities. 10 .

\section{KOCHIA TRICOPHILA.}

A pretty half-hardy annual $\approx$ to 3 feet in height, which grows into a periect pyramidal shaped cypress-like bush with feathery, lightgreen foliage, deepening as the season advances until it becomes a lovely crimson hue about September. Excellent for edging or hedging.

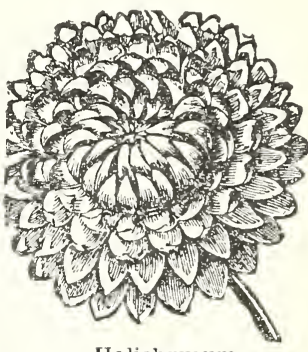

Helichrysum.

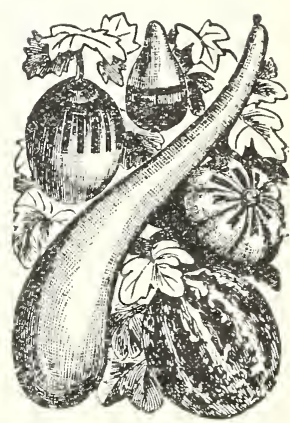

Mixed Gourds. Pki. 10c.

IRUDZU VINE (Jack and the Bean Stalk)

An extrentely fast growing, hardy vine. Its large bright-green leaves make dense shade. Bears rosy-purple. pea-shaped flowers toward the end of August. Thrives anywhere. Ist. 10c.

\section{IIINUM.}

Grandiflorum Rubrum (Crimson Flax)

2 feet. One of the most brilliantly colored of summer annuals, flowers glowing crimson-rose, very beautiful in beds and borders, and may be had in bloom from May to Cetober by successive sowings. Pku. 10c.

\section{I.tTIVUS (Lupine)}

Free flowering, easily-grown annuals, with long, graceful spikes of rich and various colored pea-shaped flowers; valuable for mixed borders, beds and ror cutting; prefers a iitle shade. Mixed. Plit. 100.

\section{HELINTHUS.}

The Helianthus, or Sunflower, is well known. Many improvements have been made upon it, the newer varities being now considered indispensable for cut flowers. In bloom from June until frost. 3 to 4 feet.

Muliforne Forms a dwarf plant. Each branch carries double goldenyellow flowers. Pkt. 10c.

\section{LOBELIA.}

Little, round, compact plants, 4 to 6 inches high, forming little mounds of bloom; splendid for hanging baskets; also for edgings or flower beds.

Dwarf. Beddinǵ Qucen,
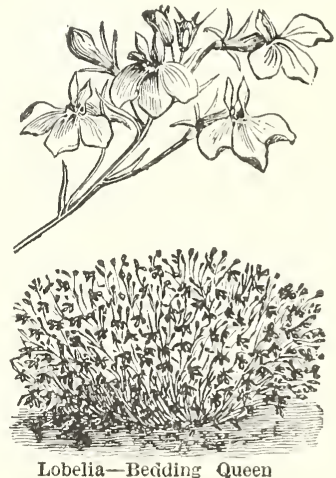

Lobelia-Beciding Queen 


\section{LARKSPUR.}

\section{ANNUAL VARIETIES.}

These include the Rocket sorts, which should be set 5 to 6 in. apart, and the branching kinds which require 2 feet apart. They are among the most showy, graceful and effective plants. Handsome, feather-like foliage and long spikes of lovely flowers - white, pink, blue and violet. Fine for cutting. In bloom July to October. Prefer cool, moist soil. Dwarf Rocket, mixed. Pkt. 10c.

Moschatus, (Musk Plant). Useful for hanging baskets. Small yellow flowers. The foliage emits a strong,

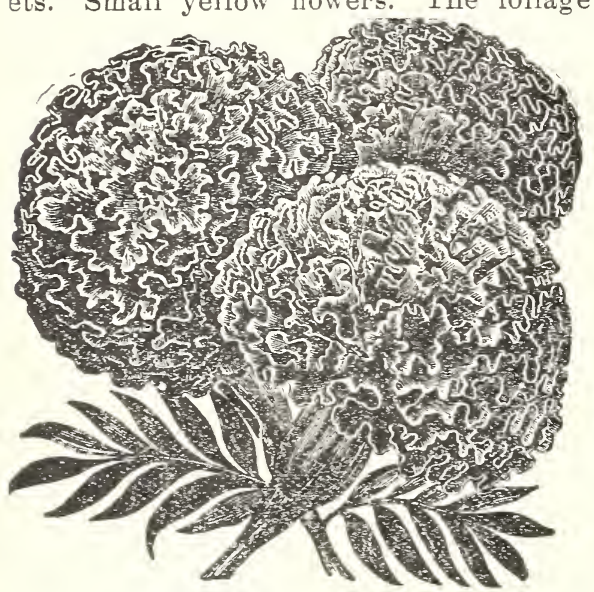

Marigold E] Dorado.

\section{MARIGOLD.}

Marigolds are among the easy plants to cultivate. They make a splendid show in the garden from June until frost. African varieties grow tall. Their lowers are large and all of one color. French varieties are of dwarf habit and small flowered; some have handsomely striped or gilt-edge petals.

Double African, mixed. Pkt. 10o. French Marigold. Pkt. 100.

MARVEL OF PERU, Or FOUR O'CLOCKS.

This is another good old fashioned flower, bearing hundreds of flowers during the season, of white, yellow, crimson and violet, some varieties combining two or more of these colors in spots, flakes and splashes in such manner as to give the flowers a most bizarre effect.

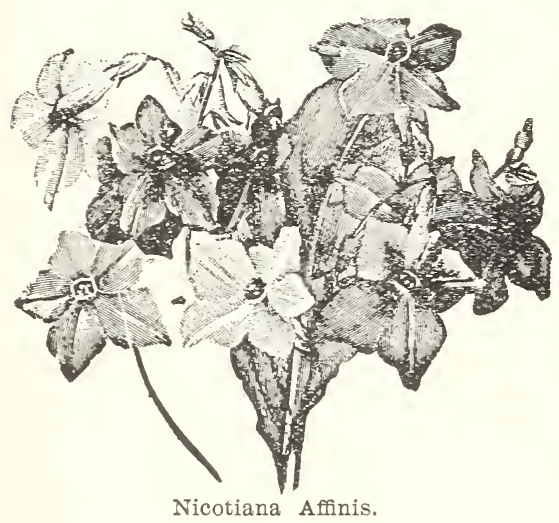

NICOTIANA.

Ornamental Tobacco, Evening Star. An annual that is ornamental, either as a pot or garden plant. Produces clusters of long, white tubeshaped flowers, fragrant towards evening. Of easy culture.

Affinis. White. 2 feet. If taken up in the fall, cut back and potted, will bloom all winter. Pkt. 10c.
Four O'Clooks, Mixed.

Pkt. 10c.oz. 20c, $1 / 4 \mathrm{lb}, 40 \mathrm{c}$.

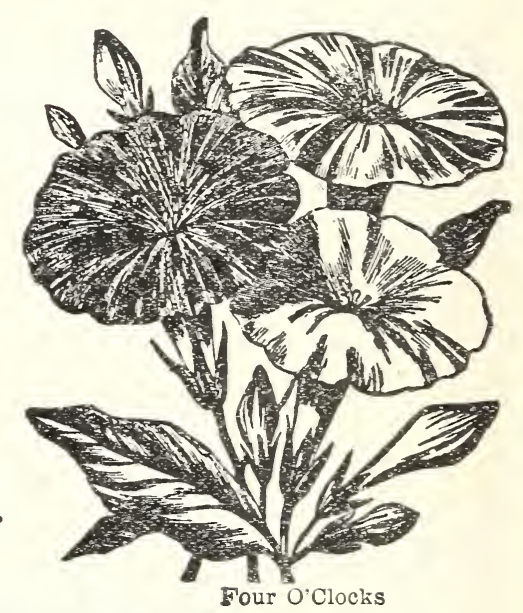

MOON FLOWER.

Tall-growing annual climbers, related to the family of Morning Glories. As Moonflower plants have dense foliage, they are useful to cover trellis work, rerandas, etc. Plant seeds out-of-doors when warm weather sets in. Pkt.10c.

\section{MORNING GLORIES.}

Rapid-growing annuals, useful for covering arbors, porches and trellises. The foliage is pretty and every morning the vines are clothed with showy flowers in a variety of colors. Sow where plants are to bloom, as they do not transplant well.

\section{Morning Glory. Mixed Colors.} Oz. 15c. Pkt. 10c,

\section{Japanese Morning Glory.}

Imperialis Japonica. From Japan. Distinct strain, embracing varied types of foliage, combined with immense size of flowers and wonderful variety of colorings. Pkt.10c,oz. 20c

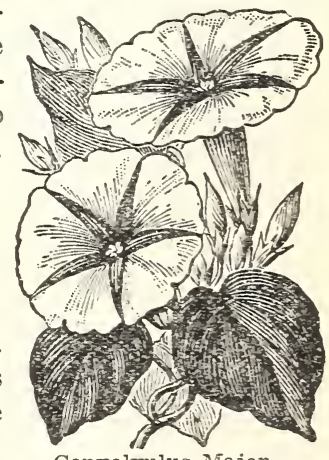

Convolvulus Major. Morniné Glory. 


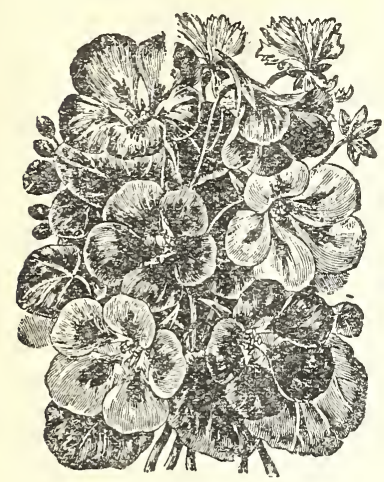

Nasturtiums

\section{NASTURTIUMS}

Dwarf Varieties 1 Ft. There are few flowers that can compare with Nasturtiums in richness and variety of color, freedom of bloom, ease of culture and general usefulness. They are suitable for bedding and edging, grow quickly, thrive in the poorest soil and fur. nish the greatest abundance of long lasting, sweet scented cut flowers. Pkt., 10c. oz. $15 \mathrm{c}, 1 / 4 \mathrm{lb}, 40 \mathrm{c}$.

Tall or Climbing Varieties. The tall sorts are luxuriant climbers for verandas trellies, fences, etc. They are especially adapted to the covering of unsightly railings anc to trail over rough ground, their flowers are generally larger than those of the dwarfs The seed pods can be gathered while green and tender for pickling. Plkt., 10c. oz., 15c. 1/4 Ib., $40 \mathrm{c}$.

\section{PANSY}

By hybridization and selection skilled specialists have greatly improved the Pansy, so that a new strain known as

Giant Flowered Pansies has been developed. This, too, is constantly being improved upon by added colors to the extremely large flowers. In size the blooms are marvelous, some being four inches in diameter; in beauty their magnificence is unsurpassed; in colorings they are superb and incomparable. Price per Pkt. 15 c.

Florists' Mixture. It contains seeds of all the best Pansies, including the newer varieties. A bed grown from this seed will give you a grand disp!ay. It is the best Mixture that money can buy. Each, per Plkt, $10 c$.

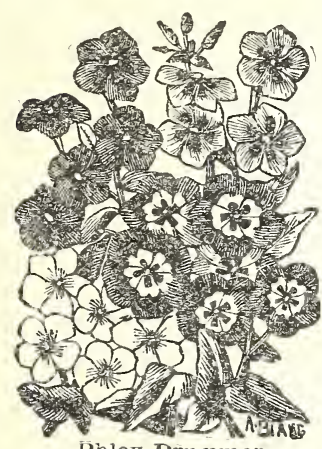

Phlox Drummor

\section{PHLOX}

The colors range from purest white to deepest bloodpurple or crimson. Seed may be sown in the open ground

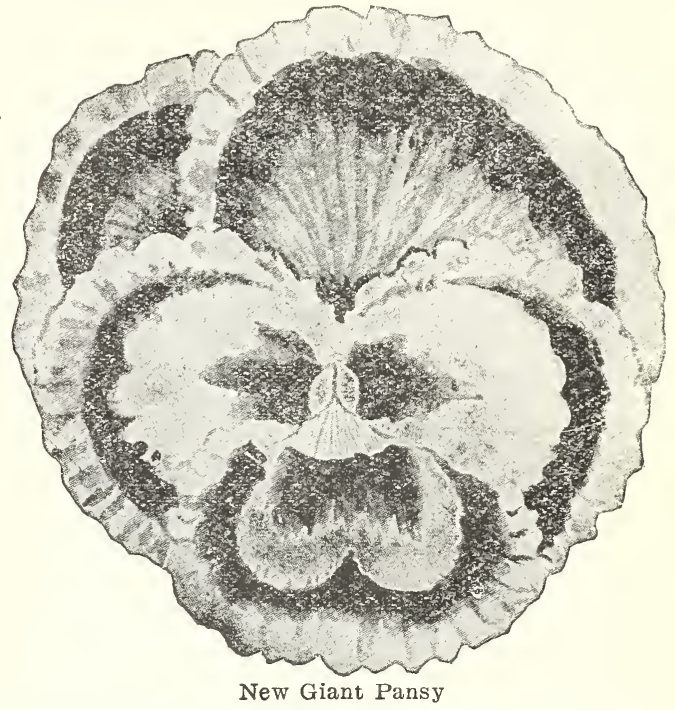
any time after danger from frost is past, or in the hotbed earlier, and trans. planted. The seedlings should be set out about a foot apart; if too thick, mildew attacks them.

Phlox Drummondii. The old fashioned favorite variety, mixture contains jll colors. Pkt., 10 c.

Large Flowering Phlox. The large flowering Phluxes show decided im. provements in size, shape and color over the ordinary Drummondi class. The flowers are round, the petals overlapping. $1 \mathrm{ft}$. H. A. Mixed Pkt.10c.

Dwarf Phlox. The little bushy plants rarely grow over eight inches high. Throughout the entire season they are full of flowers. They are recommended for culture in pots, beds, or edgings of borders.

Mixed, Pkt. 10 .

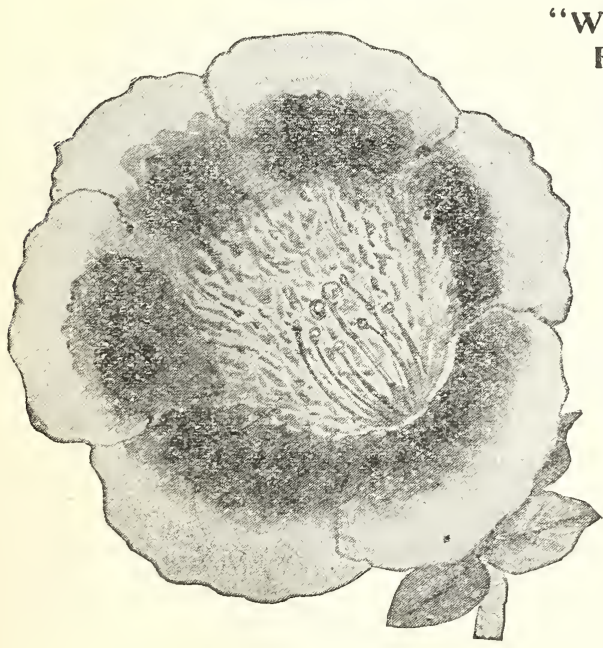

"WILD GARDEN" Flower Seed.

Each package contains about 100 varieties of hardy annual flower hardy annual fower and wherever planted will insure something new almost every day. Is suitable for sowing in flower beds on which no care will be bestowed. To those who cannot bestow the necessary care required in a neatly laid out flower neatly laid "Wild Gargarden, the "Wresents a good den" presents a good
substitute. Pl. 10c.

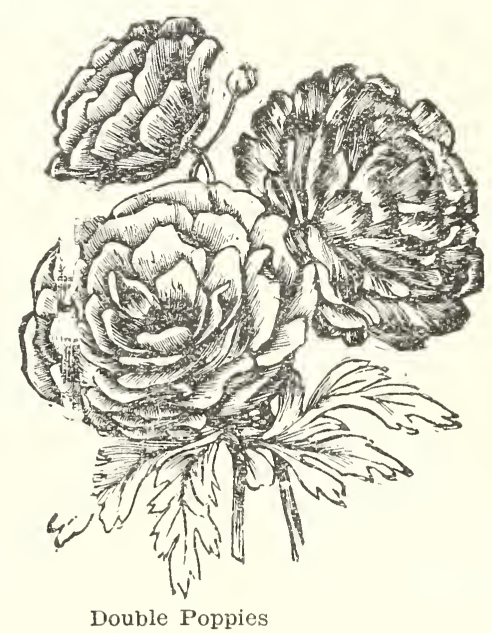

POPPIES

These old-time-favorite flowers have been greatly im proved in late years. During the blooming period few, is any, will give such a wealth of color. Annual sorts should be sown where to bloom, as they do not bear transplanting. Double Ponvies. mixod. Pkt.. 100. 


\section{PORTULACA ROSE MOSS}

This plant will grow and bloom profusely in a dry, hot situation, where almost any other plant would soon die. Easily transplanted. In sowing mix the seed with dry sand to insure an even distribution. Sow in May when the ground is thoroughly warmed through.

Single, mixed, pkêt., 10c,

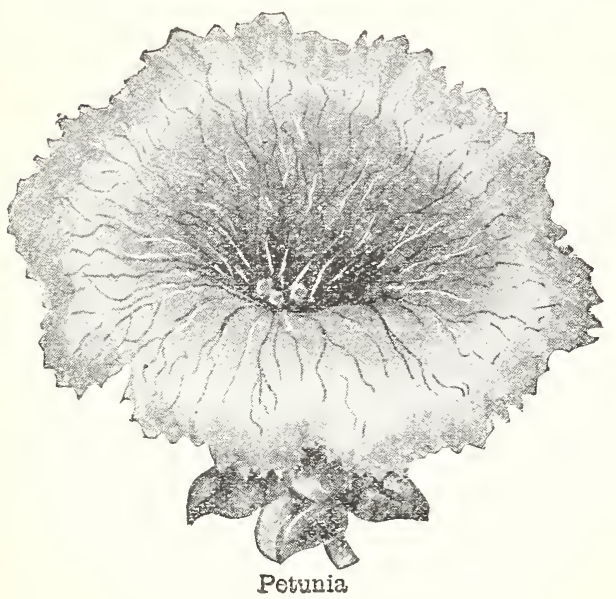

RICINUS.

(Castor Oil Plant)

Rapid-growing plant with palmlike foliage and showy fruits. Fine for center plants in beds of Cannas, etc. 6 to $15 \mathrm{ft}$. H. H. A.

Zanzibarensis. $15 \mathrm{ft}$. Leaves vary in color from light green to purplish red. Plikt, 10c.

\section{SCABIOSA (Mourning Bride)}

The Scabiosa is an old favorite, and of late years has been greatly improved. The flowers are borne on long wiry stems, in white, yellow, pink, scarlet, crimson and maroon. Beautiful in the garden, and excellent for bouquets. 12 to 18 inches high. H. H. A.

Dwarf double waixed, pkt., $10 \mathrm{c}$.

\section{SWEET PEAS}

Seeds should be sown as early as possible, in drills 6 inches deep. At the time of planting, cover with 1 inch of soil only, and fill in the drill as the young plants grow, taking care not to cover the top of the plants. A deep rich soil and a sunny situation is best suited for their needs.

\section{ROYAL MIXTURE.}

There are pure whites and white striped with other colors,

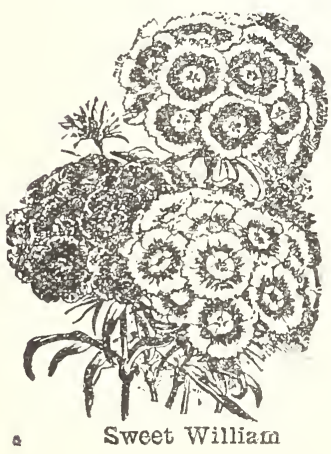
fiery scarlets, blues, steel and purple, pink, all shades; orange, yellow, so many we cannot specify.

\section{Plkt.10c, oz. 15c.}

\section{Mixture of "Sponoer" Sweet Peas}

Their grand flowers with their charmingly waved petals are borne in clusters of three or four, and sometimes more, on one stem and make grand cut flowers for vases, etc. Their delicate coloring and fragrance cannot be excelled and scarcely equaled by any other flower. Ilte 10c, oz. 25e.

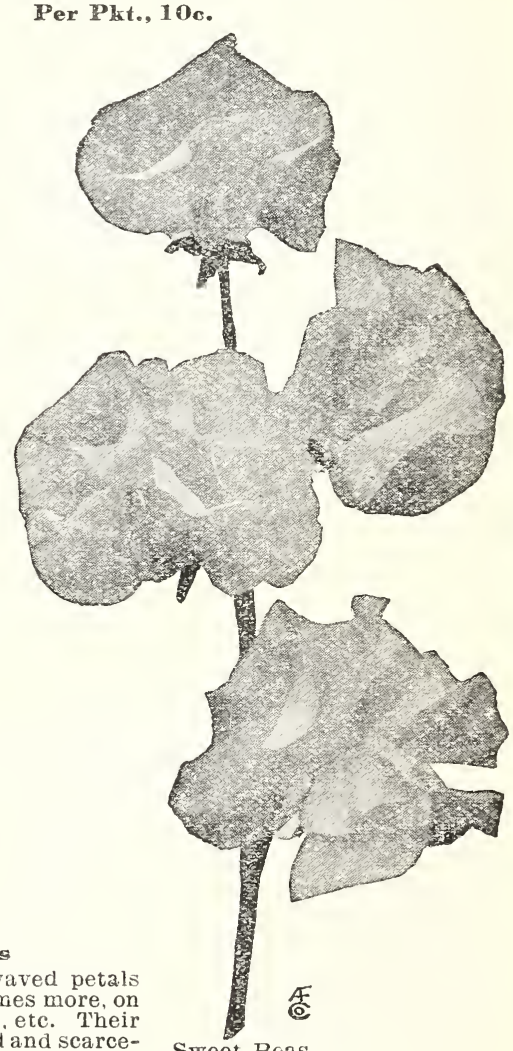

SWEET WILLIAM

(Dianthus barbatus). The plants produce a succession of flower clusters, thus affording splendid bloom for several weeks. The colors are exceedingly varied, ranging from white through many shades of lilac, red, carmine, crim. son, maroon to nearly black, usually two shades to each plant, Sinǵle, mixed, pkłt, 10c.Douhle, mixed, pkt, 106. 


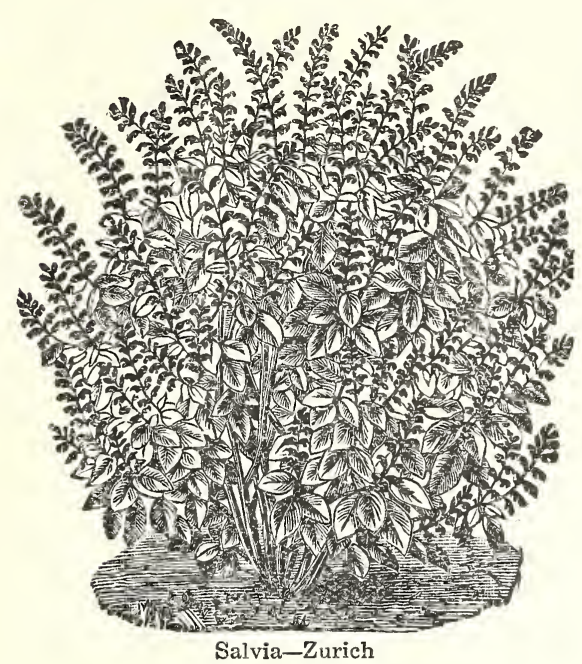

SALPIGLOSSTS.

Very showy bedding or border plants with richly colored, funnel-shaped flowers which are purple, scarlet, crimson, yellow, buff, blue or aimost black, beautifully marbled and penciled. Mixed, Pkt. 10c.

\section{SENSITIVE PLAN'T.}

Interesting plant with pinkish-white flowers. Its fern-like leaves are extremely irritable, closing and drooping when touched. Pkt. 10c.

CHINESE WOOLFLOWER (Celosia Childsii).

A magnificent garden annual that has proven a great success everywhere. Plants grow two to three feet high. Scores of branches are thrown out, each bearing a ball of colored wool. but not so large as the central one. All these branches support numerous laterals with small heads of bloom mixed with fresh green foliage. None fade in any way until hit by frost. Can also be dried for winter bouquets. Pkt. 10c.

\section{WHLD CUCUMBER.}

For a rapid climber it has no equal, it will reach a height of thirty feet in one season, it is thickly dotted over with pretty white fragrant flowers followed by quantities of ornamental and prickly seed pods. Pkt. 10e.

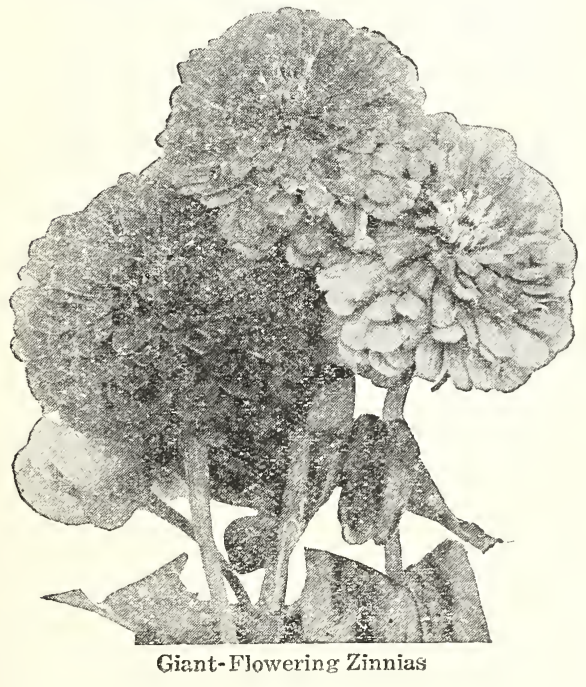

SALVIA SPLENDENS (Scarlet Sage).

The Salvia Splendens, or scarlet sage. is a standard bedding plant that keeps the garden bright with color until late in autumn. This plant lends itself to many uses; it makes a good pot plant, does well in window boxes, and is useful for cutting to give color. Its best use, however, is as a hedge or border plant, where long broad bands of intense color are desirable.

Fireball. A dwarf, early flowering sort, having very erect spikes of brilliant scarlet flowers. Pkt. 15e.

Drooping Spikes. The bright scarlet flowers are produced in such quantity that the spikes droop by reason of their weight. Blooms until late fall. I'kt. 10c.

Zurich. Said to be the best of the Scarlet Sages. It is more compact than Fireball, somewhat earlier, and blooms with equal freedom. As it grows only a foot high. it is suitable for pot culture. l'kt. 15e.

\section{S'TOCKS, or LEVIKOYEN.}

These are among the best and most popular of the garden favorites. In brilliancy of color and general effect they are unsurpassed. They are equally fine for bedding, borders, massing or for pot culture. They are very thirsty plants and must be watered in dry weather. They produce blossoms in all shades of crimson. rose, lilac and white, and yield a delicious odor. Large-Flowering, Pkt. 10c.

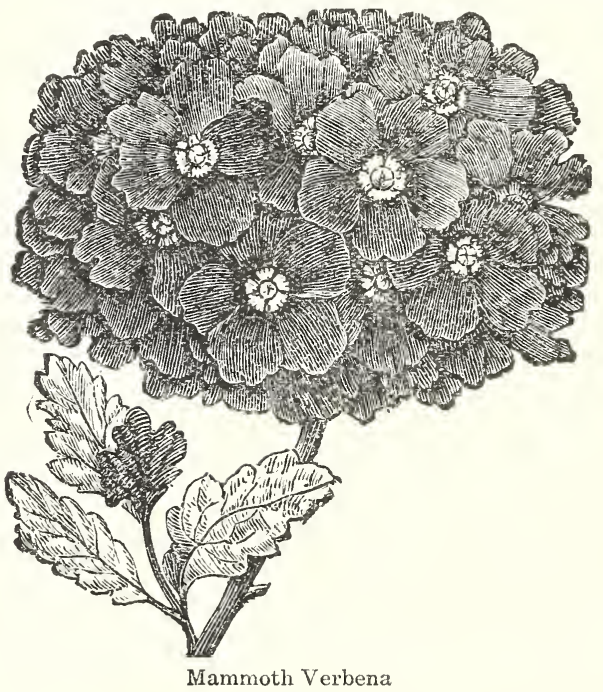

VERBENA.

Verbenas are some of our most showy and satisfactory garden companions, the colors are rich and varied, all the tints of the rainbow are represented with all possible variation of stripes, veins and eyes of contrasting shades, also solid colors of red, pink and white. Mammoth, mixed. Pkt. 10c. WALLFLOWER (Goldlack).

Wallfowers are old time favorites, the peculiar sweet scented fragrance of their flowers and the oriental coloring in rich red and yellow, make the flower very effective. Mixed, rkt. 10c.

\section{GHANT DOUBLE ZINNMAS.}

Double Dahlia-flowered. The latest development in Zinnias, bearing flowers of mammoth size and in form like a perfect decorative Dahlia. As the result of painstaking care and selection the size, form and coloring has been much improved the form and coloring has been much offer contains a past season. The mixture we offer contains a Mixed. Plikt. $10 \mathrm{c}$.

Giant Flowering Double Mixed, Plat. 15e.

New Double Dahlia Flowered zinuias Mixed. Pkt. 15e.

Crimson Monareh. The largest and best of the truly red shades. Pkt. 2ac. 


\section{Hardy Perennial Plants}

If wanted by mail, adi ฮc each, for postage.

The ever increasing demand for Hardy Perennial Border Plants is the very best indication of the popularity they enjoy and which they so richly deserve. Once planted, they become a lasting pleasure. We have carefully selected the following which are considered the best, all of them, in addition to their great beauty, being especial

ACHILle. (The Pearl). Pure white double flowers in dense clusters, blooming freely through the summer; fine for cutting pur-
poses and cemetery use. Height, 2 feet.

AQUILEGIAS, OR COLUMIINES (Lang-spurred Hybrisis). This is the most admired type of Columbines. The plants are of strong, thrifty growth. The flowers of largest size vary in color through charming tones of cream, pink, lavender, blue, white, scarlet and yellow.

Each 20c, 3 for 50c.

German Iris-Flag Iris or Fleur de Lis

These Irises are deliciously fragrant, large and handsome, more or less beautifully mottled in the veined, in the "Falls" while the beards range from delicate primrose to orange. Their beauty rivals that of the Orchid. In colors there are the richest yeltense purples and tense purples and softest mauves softest $m$ a u ves ful claret-reds. There are also whites, and primroses, and bronzes of every imaginable shade.

Thrive in city or country equal-

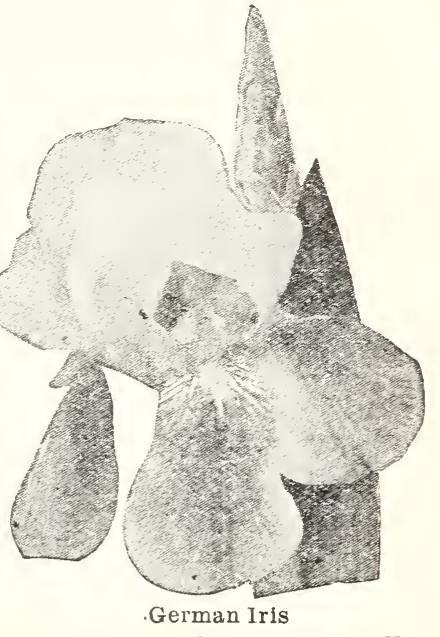

cause of the great range of color, it has been called the "Rainbow Flower". It is also called the "Poor Man's Orchid." They bloom in June and July. Any good garden soil suits them. Height 18 to 24 inches. Avoid planting too deep, barely covering the rhizomes (creeping root stems) being quite the rhizom

"S" refers to the three standard, or upright curling petais; "F" to falls or drooping petals.

CAPRICE. (New). "S" Reddish purple; "F" Deeper, self-colored. One of the best red Irises.

CHARLES DICKENS. "S" Blue; "F", Each $25 c$ fused dark purple. Each 15c, 2 for 25 c ISOLINE. "S" Lilac pink; "F" Purplish old rose, with golden throat and yellow beard. Each 25e

KING OF IRIS. (New). "S" Lemon yellow; "F" Deep brown and yellow. One of the most beautiful of all Irises. LOHENGRIN. Large handsome silvery-mauve Each 25e. MME. PACQUETTE. Bright rosy claret, early and beautiful. Sweet scented. Each 25e MARS. "S" Light yellow; "F" Pale yellow with violet blotches. Each 15e, 2 for 25c. IONSIGNOR. Tall, large blossoms borne in profusion. "S" Blush lavender: "F" Violet with white pencilings at throat. A truly magnificent specimen. MRS. H. DARWIN. "S" Clear waxy white; "F" RHEIN NIXE. (New). " $\mathrm{S}$ " White, very "F" Rich violet purple with distinct narrow white edge. A charming flower.
GERMAN IRIS MIXED. - Each 15c, 2 for 25e IRIS PUMILA HYBRIDA. Each 15c, 2 for 25c. German Iris, growing about 8 inches high, very free blooming, sweet scented. These bloom about two weeks before the German Iris.

CYANEA. Rich royal purple with black shading. EXCELSA. Beautiful lemon yellow shaded darker

THE BRIDE. A large showy pure white.

Each 15e, 2 for 25e.
CHRYSANTHEMUMS (Hardy), These are universally popular for outdoor bedding. They produce a lavish profusion of blooms, giving eolor, life and beauty to the garden just at a time when other plants have been destroyed by frost or looking their worst. They are quite hardy if planted in a well-drained position and, with a slight covering of leaves or litter during the winter, will take care of themselves after once planted. Double red, white, yellow, pink. Each 20c, 3 for 50c. ARTEMSIA. A most useful class of plants either for the border or for filling in within the shrubbery. Though not remarkable for their flowers, the foliage of the sorts offered is very ornamental.

Abrotanum (O1d Man, or Southern-Wood) Dark green, finely cut foliage, with pleasant aromatic odor; 2 feet. plant much prized for its fragrant foliage.

Each 15e.

BLEEDING HEART (Dielytra Spectabilis.) Charming hardy plants with much-cut foliage and flowers of interesting structure. Easily cultivated and very highly prized for border and cemetery planting because of their bushy growth. Flowers are rose-colored, heart shaped, produced in early spring. $\quad$ Each 75c

Formosa. (Plumy Bleeding Heart). A dwarfedgrowing species, with finely-cut ornamental foliage, growing about 15 inches high, and producing its ECHIN ACEA. PURPUREA - (Giant Purple Cone-flower). Flowers about four inches across, of a reddish-purple with a large cone-shaped center of brown: three feet; blooms from July to October. Each, 25e.

MONARDA. (Bergamot, Red Flowering mint). Terminal heads of rich scarlet flowers, emitting a very pleasant scent. Cach, 25c.

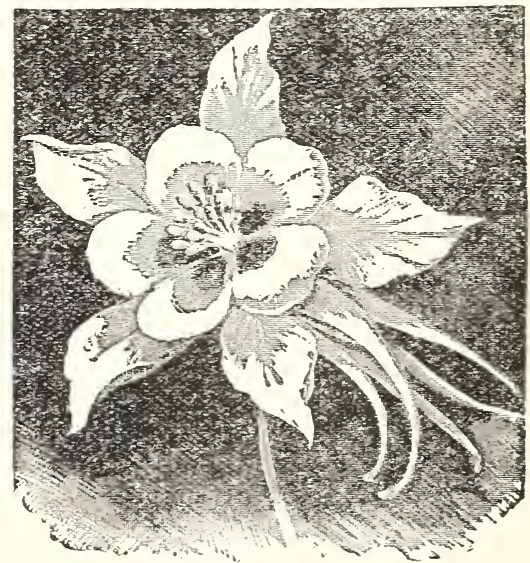

AQUILEGA (Columbine).

C A I P A N U L A MEDiA. (Canterbury Bells). Canterbury Bells are probably the oldest and most popular of all Campanulas. They are easy of pure.

Persicifolia. Grows $1 \frac{1 / 2}{\text { feet }}$ high, and produces a great number of blue flowers in loose clusters from June to July. Each 20c, 3 for 50 .

CARPATICA (Carpathian Hair-Bell). A pretty species, growing in compact tufts, not exceeding 8 inches high; flowers clear blue, held erect on wiry stems. It begins blooming in June, continuing until October. Each 20c, 3 for 50c. 


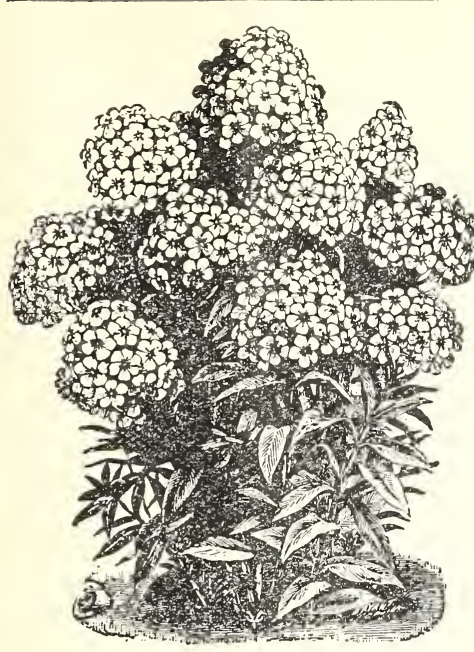

in mixed colors. 200, each, 2 for $35 c$

HARDY PHLOX. (Named sorts)

Any of the following Strong Plants, each 25e.

ANTONIN MiRCIE. (Mediuna). A beautiful

grayish lilac with white center. (Dware). Bright salmon pink, with lighter shadings and dark crimson eye. One of the best.

EUROPA. (Medium). White, distinct carmine eye, large flower. Very distinct; one of the best.

WUGENE DANZANVILLERR. (Dwarf). Soft 1 lac blue with large white center, free and continuous bloomer.

FRAU ANTON BUCHNER. The finest white variety yet introduced having the largest truss and individual flower of dwarf habit.

LeMAHDI. (Mediuna). Dark purple violet, one of the finest dark colored varieties.

MME. PAUL DUTRIE. (Medium). A delicate lilac-rose, reminding one of some of the beautiful soft pink Orchids.

MIRS. JWNIINS. A very free flowering early variety of medium height producing immense panicles of pure white flowers.

ROSENBERG. (Medium). Bright reddish-violet with blood-red eye, large truss and individual flowers.

R. P. STRUTHERS. (Medium). Rosy-carmine with claret-red eye, fine.

SELMA. (Medium). Large flower, pale rose mauve, with claret-red eye.

TAPIS BLANC. (Dwari). Pure white, immense heads. The best dwarf Phlox in cultivation, fine for cemetery planting.

VON GOETHE. (Medium). Pure clear pink with white eye.

WDDi. (Medium). A much admired violet-blue with white eye; a rich colored form of Antonin Mercie.

PHLOX SUBULATA. (Moss or Mountain Pink)。 An early spring-flowering type, with pretty mosslike evergreen foliage, which, during the flowering season, is hidden under the masses of bloom. An excellent plant for the rockery, the border, and invaluable for carpeting the ground or covering graves. MYosotis PALUSTRIS. (Forget-Me-Not). The true forget-me-nots-a lovely dwarf plant for damp places, spreading rapidly and carpeting the ground. Make excellent edgings and carpeting planted with late-flowering tulips. Flowers blue with white throat. Fine for cemetery planting.

Wach 20e, 3 for 50e.
HOLYHOCK (Althea Rosea). Growing 5 to 6 feet tall, these plants produce a pleasing effect planted either in rows on the lawn or among shrubbery. They require a deep rich soil, and a sunny situation, and will repay for a little extra pink.

given them. Double red, white, yellow, pink.

GRASSES (Ornamental. Variegated Ribion Grass, or Garlener's Garters.) Large variegated foliage; an excellent Grass for bordering large beds. Wach $15 e, 2$ for $25 e$.

HARDY FWRNS. They do the best in a shady or semi-shady position in well-drained soil, where they can be liberally supplied with water during dry weather. Each, 30e.
HIBISCUS. New Giant-Flowering Mallow Marvels. A robust type of upright habit, producing an abundance of flowers of enormous size in all the richest shades of crimson, pink and white succeeding in any suny position with a liberal supply of water, blooming from early in July until late in autumn. Each sac.

HELANTHUS (Hardy Sunflower). Multiflorus Plenus. 4 to $5 \mathrm{ft}$. Double yellow flowers, useful for cutting. July-Oct. Resemble large yellow Dahlias. Wach 20e, 3 for $50 c$

LINUM-PIRENNE. (Flax). A desirable plant for the border, with light, graceful foliage and blue flowers produced through the entire summer if cut down after the first blooming.

Wach 20 , 3 for $50 c$

LYCHNIS. All of the Lychnis are of the easiest culture, thriving in any soil, and this, in addition to their brightness, has brought them into high favor with lovers of hardy plants. Perhaps no class of plants has more common or popular names, of which the following is but a partial list: Campion, Jerusalem Cross, Lamp Flower, Maltese Cross, Ragged Robin, etc.

Haageana. Brilliant orange-scarlet flowers in May and June; 12 inches.

Viscaria, Double Red. Forms a dense tuft of evergreen foliage, and in June sends up spikes of handsome, double, deep ref, fragrant flowers; 1 foot. Price Each 250 .

LUPINS (Hardy Garden). Effective plants, producing large spikes of flowers. They require only well-prepared garden soil and to be kept watered in dry weather. Hardy perennial varieties, in pink, blue and white. $\quad$ Perennial Mixed, Each 25c.

MIN'T. Peppermint. The leaves and stems are used for flavoring, but particularly for the distillation of the essence of peppermint.

Spearmint. For mint sauce and juleps.

Wach 20c, 3 for 50c. PAPAVAR ORINNAALE. (The Large Oriental Poppy). A charming summer-flowering hardy plant, producing numerous leafy stems about $2 \frac{1}{2}$ feet high, with large deep crimson flowers; having a conspicuous black blotch on each petal, exceedingly showy.

RUDBECinA. (Golden Glow). Double golden

yellow flowers.

PYRETHRUM. (Roseum Hybridum Grandiflorum.) Handsome garden flowers. Their main season of blooming is in June, but if the first crop of flower stems is removed as soon as finished, they will give a fair sprinkling of flowers during the summer and autumn months. The fine rern-

SINGLE-FLOWERING. Embrace all the colors from deep red through the various shades of rose to pure white. These can be supplied in mixed colors only.

DOUBLE-FLOWERING. Choice varieties in crimson, pink and white.

RANUNCULUS REPENS FL. PL. (Bachelor's Buttons). A pretty double-flowering bright golden yellow Buttercup. Bears masses of flowers during
May and June.

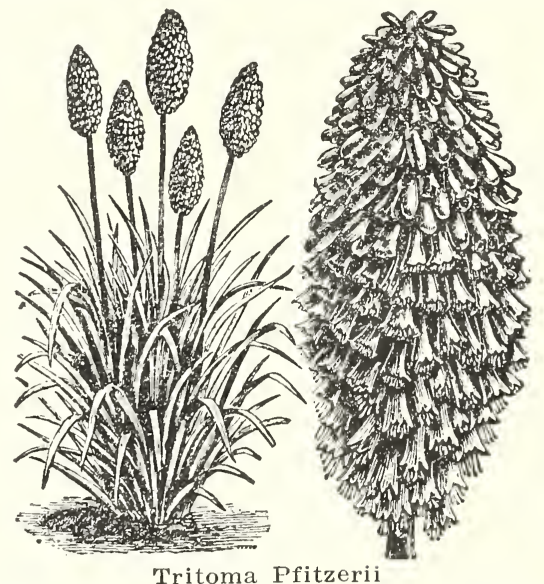

TRTTOMA PFITZERI. (THE Everblooming Flame Flower). In bloom from August to October, with spikes 3 to 4 feet high, and heads of bloom of rich orange-scariet, producing a grand effect either planted singly in the border or in masses. (See cut.) 
DELPHIVI or Hardy Larkspur. The Hardy Larkspurs are easily among the finest of all our perennial plants. The prevailing colors are rich, clear shades of blue. The plants have a long season ing the seed stalks cut out and supplying plenty of water. The dark, handsome foliage is neat and attractive throughout the whole season. The plants are perfectly hardy, Each 20c, 3 for 50e.

CHELONE (sheli Flower). Stately and handsome perennials, glowing about 2 feet high, and of show deep red flowers, during the summer and Ealch 250

BUDDLEIA (Butterfic Bush or summer Lilac).

A desirable summer flowering shrubs, beginning to bloom in July, it continues until cut by serere frost. The flowers are of a pleasing shade of violet-mauve, and are borne in dense cylindrical spikes, which are from 12 to 15 inches in length by 3 inches in diameter; it flowers freely the firs season planted. and is always admired. Each 35c.

CORNFLoiver (Perennial. Centaurea Montana). Useful and effective border plant; invaluable for cutting. Flowels blue, about an inch across. Season May to August, growing 12 to 16 inches hight. Euch 20c, 3 for 50c.

(COREOPSIS (New Double-flowering Coreopsis). One of the most popular hardy plants. The flowers are a rich golden-yellow, of graceful form and invaluable for cutting; the main crop comes during the latter part of June, but it continues in bloom the entire summer and autumn. Each 25c.

SH IST I DISY. Graceful and elegant purewhite flowers with yellow centers, lasts a long time. In bloom from June to October. Extra fine cut flowers, having long, stiff stems. Each 20e, 3 for 50e. SWEET WILLIA (Dianthis Barbatus). These old-fashioned favorites are prized border plants. There is a sreat variety of rich colors, and the flowers are very fragrant. Each 20c, 3 for 50c.

GIILL. RDI (Blanket FIower). Unequaled for rich and constant display of bloom from June unti frost. Flowers very large; bronze-scarlet bordered with yellow, Each 20c, 3 for 50c.

\section{BEAUTIFUL HARDY PEONIES}

The Peonies are among the noblest and most magnificent of our herbaceous plants. With the addition of superb newer varieties, Peonies have taken rapid strides in popular favor and are now classed as among the most popular of our garden perennials.

The colors have the greatest range, embracing white, flesh color, rose pink, salmon, yellow, scarle and crimson in lighter and darker shades.

They requile Tery lich soil, are perfectly hardy, and in planting care should be taken to select a rich, sunny place. Aroid planting too deeply, as this is often the cause of shy blooming, two or three inches of soll over the crown (eyes) being sufficient. After planting give a heavy mulching of rotten stable manure, and do not transplant the clumps for at least five years, and then only if very necessary.

ouble white. pink and red Peonies reasonably priced Peont. 3 to 5 ere roots, each 50c.

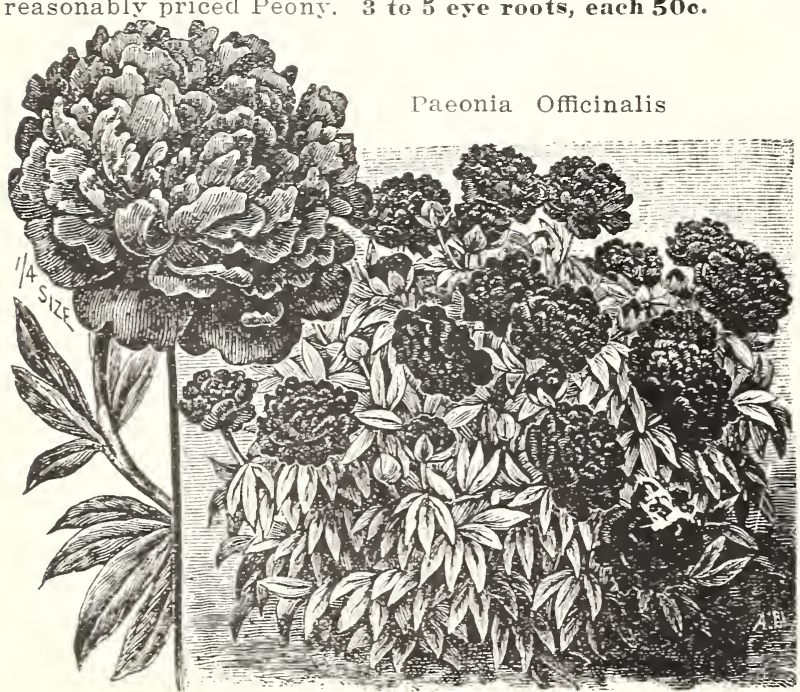

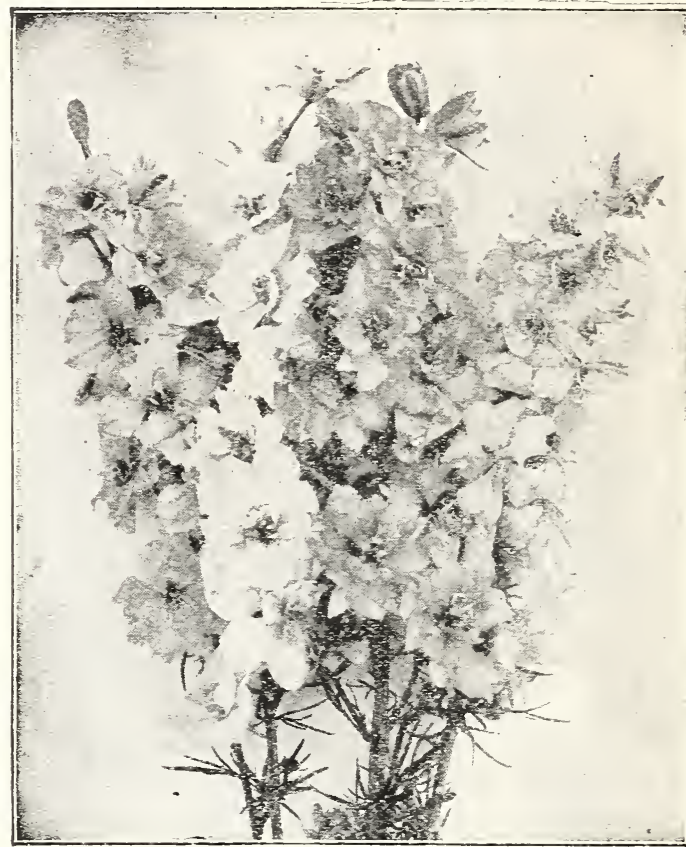

Delphinium-(Hardy Larkspur)

\section{SELECTED PAEONIES}

Famed Sorts, strong roots, with three to five eyes. The fine and newer varieties listed on this page are rely desirable and can not fail to please any cultivator. They represent the highest attainment in Paeonies and are the best of the originations of expert growers. Do not expect too much of them until well established. These can be furnished in limited quantities only.

BERLIOZ. Brilliant dark red tinted rose. A he keeper, Very late. Each 75c.

DUCHESS DE NEIOURS. A very fine cupshaped bloom; sulphur-white changing to pure white Has a fine bud and is particularly beautiful when half open. DUKE OF WELLINGTON. Soft white, with pale creamy white center. Fine shape. Early.

EDLLIS SUPERBA. Bright mauve Each 50c. mixed with lilac fragrant, strong upright stem, free bloomer, early, one of the best commercial pinks.

FESTIVA MAXIMA. The best known Peony. Flower of immense size. Seven to eight inches in diameter, snow-white with some red spots on the edges of the center petals. Tery sweet, early.

Each 50c.

FELIX CROUSSE. One of the best red sorts. Large double ball-shaped flower; a free bloomer. Tery desirable. Late mid-season. Each 75c.

LOUIS VAY HOUTTE. One of the most conspicuous dark varieties; rich, dark carmine, with slightly silver tip borne well above the foliage; strong grower

Each 75c. MODESTE GUERIN. Very large bomb-
shape, full and compact Superb solferino red. 'Very free-flowering and fragrant. Exceptionally strong rigid stems. Midseason. An extra good variety. Each 75c.

IIDAII DUCEL. Enormous, globular and compact bloom. Literally packed with petals, which are somewhat incurved like chrysanthemums sink with silvery reflex. Holds its form and color to the end. A magnificent cut-flower variet and wonderfully effective for landscape work. Fragrant, early: midseason bloomer.

Each 75c.

QUEEY VICTORIA. White, center petals tipped carmine, large, full bloom; one of the best flower sorts, early. Each 50c.

OFFICINALIS RUBRA PLENA. This is the old-fashioned red, the most brilliant of all red Pecnies. Early and splendid cut flowers. 


\section{Bulbs for Spring Plantinǵ}

Bulbs are of easiest culture, inexpensive and require but little care. They are almost certain to grow. Put them in the ground out of doors in April and May. Some will bloom in June, and all during the same year as planted.

\section{AMARILLIS.}

There are many species of Amaryllis, all producing large, drooping, lily-like flowers, varying in color from richest crimson and scarlet to pure white and striped with crimson or scarlet. Some of the flowers measure from 6 to 9 inches across.

All of the varieties here listed are of the easiest culture. They recuire abundant moisture when growing, but at their season of rest water should be given sparingly. Winter the bulbs in house or cellar. If in pots, do not remove from soil.

Atamaseo Alba (Fairy Lily). For the garden, set out in spring and lift in autumn like Gladiolus, White flowers. Each 10e, 3 fon 25e.

Atamasco Rosen. Rose-pink flowers, 3 to 4 inches across. Wreh 15\%, 2 for anc.

Belladonna Major. Fine variety for fall blooming, very free-flowering and fragrant. Flowers a lovely shell-pink color, stems 2 to $2 \frac{1}{2}$ feet high. Each äc.

Johnsoni. Scarlet with white stripe. Each 50c.

Equestre. Orange scarlet. Each zac.

\section{SPOT'ED LEAVED CALLA LILIES.}

The varieties offered below succeed best when treated in the same manner as Gladiolus, Tuberoses and other summer-flowering bulbs. They should be planted in the open border in a dormant condition when danger from frost is over in spring, and will then flower during the summer months. In the autumn dig and store through the winter as you would potatoes.

Golden Yellow (Pichardia Elliottiana). This is the best of the Yellow Callas, its flowers being as large as the popular white variety, but of a rich lustrous golden-yellow of velvety texture; the foliage is dark green, with translucent creamywhite spots, which adds much to its beauty. Strong bulbs. Fach 40e.

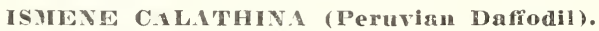

A grand summer-flowering bulb, producing with great freedom large Amaryllis-like, pure white, fragrant blossoms. Keep the bulbs in a dry, warm place, and plant out in June. Bulbs can be taken up in October and after a few weeks' rest, potted and flowered in the house in the winter, or kept over for planting out another season. Each 20e, 3 for 50 .

CINYAMON VINE OIR CHINESE TAM.

A climbing plant which in some portions of the country lives over winter out of doors. It grows rapidly, soon covering a large space with its heartshaped, glossy green foliage. Flowers, white, with the fragrance of cinnamon. Medium size, $\mathbf{1 0}$ eack, 3 for ase; Extra size, 10. ench, a for 2oc.

\section{CALDIET (Flentant's Farg).}

A vigorous grow ing plant which has tremendously large, pendulous leaves borne on long stiff stems. In rich soil, with an abundance of moisture, assiume very large growth and is most effective either singly on lawns or planted in centers of beds or centers of beds or other bloom ing plants.

First size, each 10c Medium size,

Large bulbs,
each 25e Mammoth bulbs, each $35 \mathrm{c}$

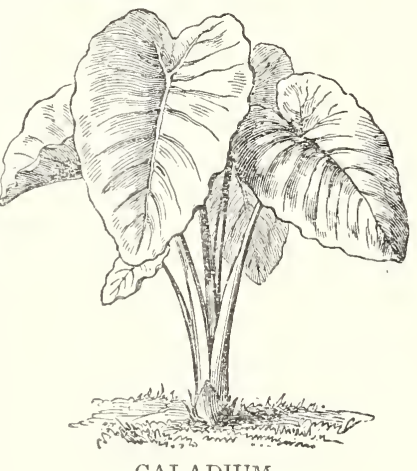

CALADIUM

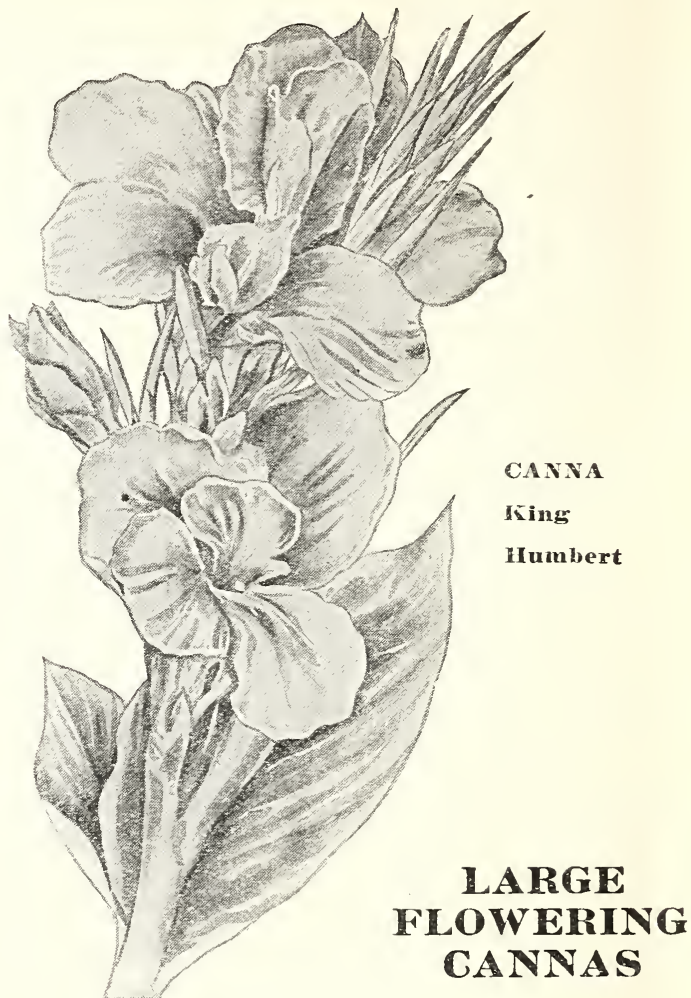

Few plants so trifling in cost will make such a beautiful display in a short time as cannas. With their enormous clousters of brilliant flowers, borne on spikes above broad leaves of green or bronze in tropical effect, makes them one of the most admired summer flowering plants of today. The dry roots can be planted about the first of May or as soon as the ground is warm.

SELECTED NAMED CANNAS (Dormant Tubers).

Charles Henderson (Green). Bright rich crimson, an old-time favorite, $3 \frac{1}{2}$ feet. Each 10c, doz. \$1.00.

City of Portland (Green). Broad, rounded petals opening wide on eavily filled trusses, flowers produced in great profusion. Color a beautiful rosepink, 3 to $4 \mathrm{ft}$. Wach 15c., doz. \$1.50.

Firebird. Green foliage. The petals measure and sometimes exceed $2 \frac{1}{2}$ inches across, and the color is a glistening scarlet without any streaks, spots or blotches, $3 \frac{1}{2}$ feet. Each 15e, dioz. \$1.50.

King Humbert (Orchid). "King Humbert" is the one ideal Canna. It has flowers six inches across, in trusses of gigantic size; of a brilliant orangescarlet with bright red marking. The foliage is broad and massive, of a rich coppery bronze; bold and effective, $3 \frac{1}{2}$ to 4 feet. Each 10e, doz. \$1.00.

Souv. de A. Crozy. 3 feet. The flowers are scarlet crimson bordered yellow. Green foliage. Each 15c, doz. \$1..50.

The President, $3 \frac{1}{2}$ feet. In color a rich glowing scarlet and the immense rounded flowers, seven inches across when fully open are produced on stromg erect stalks well above the large green foliage. Free bloomer and strong grower. Each 15c, doz. \$1.50.

Sellow King Humbert. Identical with King Humbert in habit of growth and flowering, and produces yellow llowers, dotted with red, and has green foliage. It will please all who try it. Some plants will occasionally give a scarlet or scarlet striped flower, $3 \frac{1}{2} 2$ to 4 feet. Each 15c, doz. \$1.50.

Cannas. All sorts mixed. Fach 10c, doz. \$1.00.

We can furnish started plants for bedding out, in season.

\section{BEGONIS (Tuberous Rooted).}

Tery desirable as pot plants for the house or for bedding out-doors.

single varieties in separate colors, such as white, pink, red and orange. Each 30e.

Double varieties. Same colors as above. Each 35c.

Grows three to four feet high. Bears pure white bell-shaped flowers on long stems. Can be used to good effect among Gladiolus, as it comes into bloom about the same time and makes a pleasing contrast. Each 15e, Ior $\mathbf{2 5 c}$ 


\section{BULBS FOR SPRING PLANTING-Cont'd}

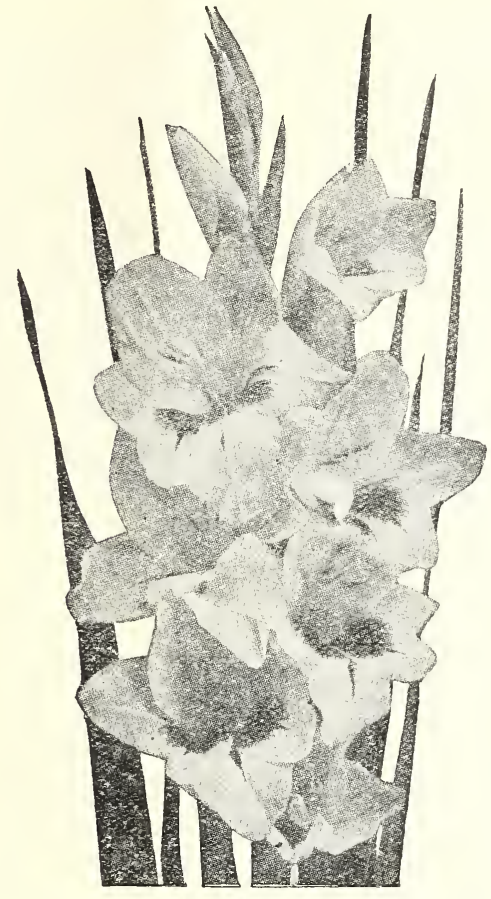

GLADIOLUS.

Well known flowers which last a long time after being cut. We have carefully selected bulbs so full of life that you cannot do other than be successful with them. They come in all colors, from very light to richest crimson. Set the bulbs six inches apart and three inches deep. Plant from: middle of April to first of June. Cut the spikes when the first bloom begins to unfold. Place iri water and the buds will expand beautifully and last for several days if water is changed daily.

\section{Gladiolus liest Named Varieties.}

Selected from the newest and best varieties of recent introduction including some old favorites.

America. Soft flesh pink, lightly tinged with lavender. Full round spike and large flower. Finch 5e. dor. 50c.

Attraction. Deep, dark, rich crimson, with conspicious, large, pure white center and throat. At once a most beautiful and attractive sort. Each 7c, doz. 70e,

Aususta. Pure white with a tint of lavender in the throat. Eack be, floz. 60c.

Baron Hulot. A deep blue of an indigo shade; an extra fine variety. Wach $7 c$, doz. $70 c$.

Brenchleyensis. Vermillion-scarlet, showy. Each 6e, dloz. 60c.

Kunderdi Glory. "The ruffled petals give to the flower an odd and original arpearance. Color, delicate cream pink, with very attractive crimson stripe in the center of each lower petal. Each se, doz. 75 c.

Mrs. Frank Pendleton. This is one of the finest varieties yet introduced. The flowers are of largest size, borne on strong, straight spikes. In color a lovely salmon-pink with brilliant deep, red blotches in the throat. A color combination rivaing many of the finest Orchids in its richness, exquisite in every way. Each Se, dow. 85e.

Niagara. Son:ewhat resembles America in type In color the flowers are of a cream shade tinted blush, and splashed with carmine in the throat. Each $S c$, doz $75 \mathrm{c}$.

Princeps. Rich crimson, with deep shadings in the throat; large white blotches on lower petals Each Se, doz. 85e.

Schwaben. A most meritorious variety of wonderful vigor, with strong erect spikes and large well expanded flowers of a clear canary yeliow with a sinall blotch of dee garnet in the throat. Each 8c, do\%. 85e.

War. Deep blood-red, shaded crimson-black. Each 10c, dor. $\$ 1.00$

Yellow Hammer. Pure yellow with small red mark in throat. Extra strong grower, Each se, doz. S5e.
GLADIOLUS IN MIXTURE.

Challenge Mixed. Made by ourselves of several varieties, all of the highest types of perfection. This mixture will please the most critical buyer. Fach 5e, do\%. 50e.

superfine rixed. This includes varieties that will produce some grand flowers. Each 4e, doz. 40e. Fine Mixed. While offered at a low price, we are sure these bulbs will make a satisfactory showing. Wachi $3 \mathrm{e}$, doz. 30e.

All offered out of doors, it is rvell to dover the surface of the soil in the fall with straw or leaves for protection. Plant Lily bulbs either in spring or fall. Set them six inches deep in well-drained ground. Early planted bulios will bloom the same year.

Each ate and wp according to stye of roots.

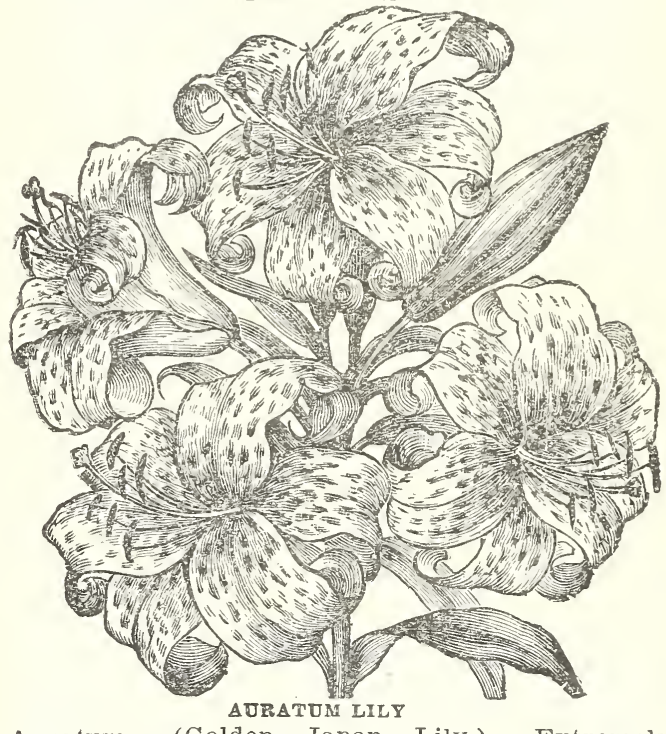

Auratrum, (Golden Japan Lily.) Extremely fragrant and very beautiful. Flowers white dotted with crimson, with a golden band running through center of each petal.

Album. Large, fragrant, pure white.

Foubrum. White, heavily spotted with rich crimson, fragrant.

Tigrium (Single Tiger Lily). Just the thing for groups in borders or to plant among shrubbely. Nlowers orange-red, spotted black. Bloom in July.

Tigrimum fi. pl. (Double Tiger Lily.) Very large double flowers.

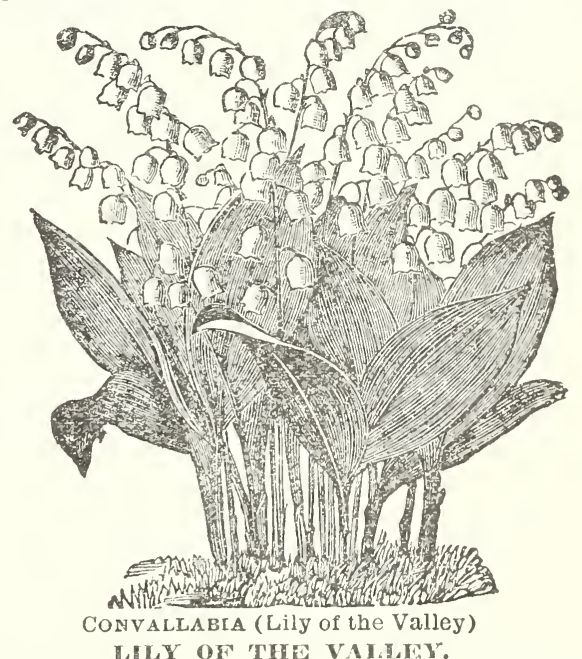

A well-known and universally admired spring flowering plant; flowers bell-shaped, freely produced and fragrant. To grow in open grould, select a partly shaded rather moist situation. Each 35e. 


\section{Bulbs for Spring Planting-Continued}

MADEIRA VENE. A tuberous-rooted, rapid-growing climber which quickly covers a large space. Fleshy, heart-shap

Small Bulbs, Each 3e, floz. 30e Medium Bulbs, Each 5e, doz. 50c. Large Bulbs, Wach Sc, doz. 75c

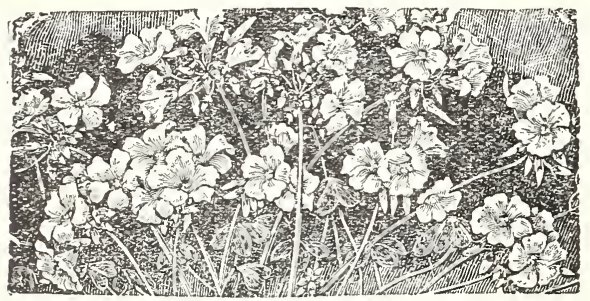

OXALIS (Summer Howering). Useful for form edgings or borders to walks and flower beds. Bulbs planted 2 or 3 inches apart will make rounded, compact plants in a little while, and they will be full of pink and white flowers all summer long.

Dozen 15c.

\section{Hardy Ornamental}

A M PELOPSIS QUINQUEFOLIA (Virginia Creeper). A native vine sometimes called Five Fingered Ivy. A rapid grower, of sturdy growth. Its leaves are larger than those of Boston Ivy. In fall they turn to bright crimson. Each 35e and up.

AMPELOPSIS VEITCHI (Boston Ivy). Desirable climber for covering walls, as it clings to the smoothest surface, clothing it during the summer with deep-green leaves which in autumn change to bright yellow and crimson. Each 50 and up.

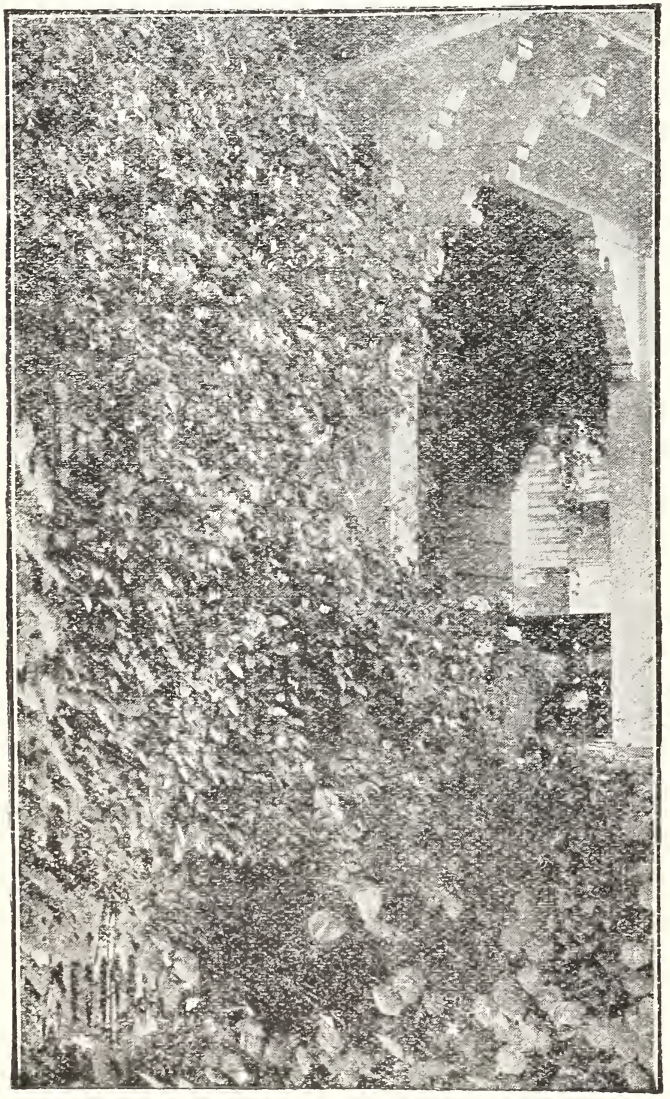

Honeysuckle, Hall's wan

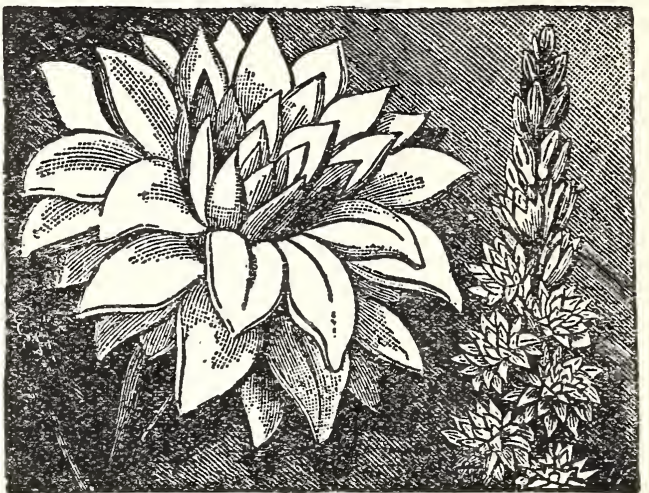

TUBERose (Exceisior Pearl). Beautiful pure white wax-like, sweet scented, double early flowerSmall Bullos, Each 3e, doz. 30e. Mediun Bulbs, Each Je, doz. 50e. Large Bulbs, Each Sc, doz, 75é.

\section{Vines and Climbers}

CELASTRUS SCANDENS (Bittersweet). A native climbing or trailing plant with large leaves yellow flowers in May or June, followed in the fall by clusters of orange-colored berries.

CLEMATIS (Large-Flowering Varieties). No other climbing plant equals in attractiveness th beautiful large-flowering Clematis. Their requirements are somewhat different from most other plants and proper conditions must be given to secure satisfactory results. They need rich, deep soil, perfect drainage, abundance of water, and. most important of all, they should be planted witl the crowns three inches beneath the surface of the soil. They seem to do best in a position where they will not be exposed to the full sun during the hottest part of the day. Hardy, but it is best to mulch them in winter.

HENRYII. Strong grower, flowers four to six inches in diameter, and pure white. Very hardy.

JAKMANII. This variety, with its strong, healthy growth hardy nature and rich, deep velvety-purple flowers, is the most satisfactory of its class. Blooms with profusion on shoots of the present season; should be pruned early in spring.

MADAME BAROY VWILLARD. Light rose, lilac shadings, Much admired.

VILLE DE LYON. Its blooming capacity is great and the flowers are of the most magnificent brilliant crimson; they are large and of beautiful circular form.

Prices of above: each $\$ 1.00$ and $u p$.

CLEMris small flowered Clematis extant. A wonderfully rapid grower, quickly covering trellises, arbors, etc. The flowers are pure white, deliciously fragrant and produced with the greatest freedom. It flowers in September, when few other vines are in bloom. This is the easiest to grow and most popular of all the small flowered vines. Fach 35e and up.

HONEYSUCKLES (Lonicera). We cannot speak too highly of this class, for covering arbors, fences, pergolas, verandas, etc. They are the best vines for ground planting under trees and if used on ter races or embankments, will prevent washing. All are perfectly hardy and improve in beauty each

HELGICA. (Sweet Scented Monthiy). One of the most satisfactory Honeysuckles, producing continuously large trusses of red and yellow fragrant flowers.

HALL'S JAPAN. A strong-growing, almost evergreen sort; flowers pure white, changing to yellow; fragrant. Covered with flowers from July to November.

SCARLE'T TRUMPE'. Bright red trumpetshaped flowers. Blooms very freely the entire season. Prices of above; each soc and up.

WISTARIA Sinensis. The favorite variety, produc ing thousands of pendulous clusters of delicate vio let blue blossoms tichly perfumed.

Each 75c and up. 
Roses should be planted in the spring just as soon as the ground can be worked, and carefully handled, as they are plants that need attention when planted. Select a good sunny location where the soil is well drained, and should the soil be heavy or clayey, some sand should be put with it A good plan is to take out the soil from 18 inches deep to 2 feet, and in the bottom place from 10 to 12 inches of well-rotted cow manure and sod, then place the black dirt that was taken out on top of this.

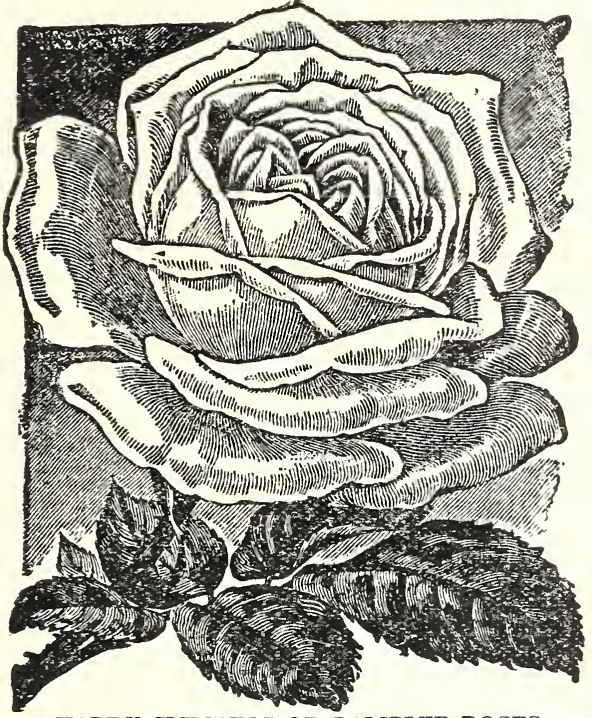

HARDY CLIMEING OR RAMBLER ROSES

The following varieties are highly valued for training over arbors, trellises and verandas; also as screens for unsightly objects, such as old buildings, fences, walls, etc. They grow ten to twelve feet high.

\section{Any of the following, each $75 \mathrm{c}$ and up.}

BALTIIORE BELLE. Pale blush variegated carmine rose and white. Flowers borne in large clusters.

CLIMBING AMERICAN BEAUTY. This variety retains the deep pink to crimson color and the same fragrance of the bush American Beauty grows to a height of 15 feet, perfectly hardy.

CRIMSON RAMBLER. So well known as to need little description. The foliage is rich, dark green: the growth rapid and diverse, During June and July the plant is covered with clusters of the brightest crimson flowers which remain on a long

DoRothy PERKINs. The most popular climbing rose of today, and as hardy as the Crimson Rambler. The flowers are borne in clusters and are very double; the petals are very prettily rolled back and crinkled. The color is a most beautiful shell pink and holds a long time without fading.

WHITE DOROTHY. A pure white sport of the well-known Dorothy Perkins, of same habit of growth and freedom of flowering; a splendid companion for the pink variety, as it flowers at the same time. A most valuable addition to this class.

EXCELSA. (Red Dorothy Perkins). A distinct variety in form, color and habit; vigorous in growth, with healthy dark, glossy green foliage. The flowers are very double, produced in large trusses of thirty to forty, and almost every eye on a shoot produces clusters of flowers. The color is intense crimson-maroon, the tips of the petals tinged with scarlet.

GARDENIA. (Hardy Marechal Niel.) Deep, rich golden yellow flowers, passing to creamy white. Blooms profusely, hardy.

PRAIRIE QUEEN. Color, bright red, changing as the flower opens to deep pink. A splendid Rose

for porches. SISTERs. Large clusters of roses shaded from white to crimson, no two alike in cluster. Fine and odd.

TAUSENDSCHON. Soft pink changing to rosy carmine. Flowers appear in large clusters. The plant is of strong, vigorous growth, perfectly hardy, and a good variety to plant where a strong climber is desired.

YELLOW RAMBLER. Flowers medium size, cup shaped, nearly full, sweet-scented; blooms in large clusters; color very light yellow.

\section{HYBRID PERPETUAL ROSES}

These are the Roses which bloom in June and at other intervals each year. Once planted, need not be lifted but protected in winter with leaves or Any of the foliowing, each 75e and up.

AMERICAN BEAUTY. Very fragrant, large crimson flowers. Blooms freely throughout the

BABY RAMBLER. Of drawf bushy habit. Brilliant crimson flowers. A good bedding variety.

FRAU KARL DRUSCHKI. Magnificent bril liant white fllowers; immense in size and produced th great freedom

GENERAL JACQUEUINOT. Brilliant crimson. Fragrant and very hardy. Esteemed as one of the most desirable roses.

GRUSS AN TEPLITZ. Color, scarlet; shading to velvety crimson. Free grower and most profuse bloomer.

MME. PLANTIER. Pure white; a favorite for cemetery decoration: very hardy.

MRS. JOHN LAMG. Soft pink, of beautiful form; exceedingly fragrant and remarkably free flowering.

IAGNA CHARTA. Deep pink, large sweet scented and of fine form, one of the hardiest roses in cultivation.

SOLEIL d'OR, OR GOLDEN SUN. Varies from orange-yellow to reddish-gold, shaded with Nasturtium-red; large, full, perfectly double flowers; a strong grower

ULRICI BRUNNER. Bright cherry-red; flowers large and full; a good strong grower and always does well.

\section{MOSS ROSES}

Very desirable for culture in open ground as they endure neglect and hardship well.

They are prized for the lovely moss-covered buds. No garden is complete without one or two Moss Roses. Colors, Red and White.

Each $75 e$.

HYBRID TEA ROSES (Everblooming Varieties) These roses are not so hardy as those mentioned above, therefore require more protection durins the winter months. They possess a delightful fragrance and beautiful shades of colors, beins such free bloomers during the entire summer which makes them desirable for cut flowers.

Our stock is oreenhouse grown and should not be set out until the sun has warmed and dried the ground well.

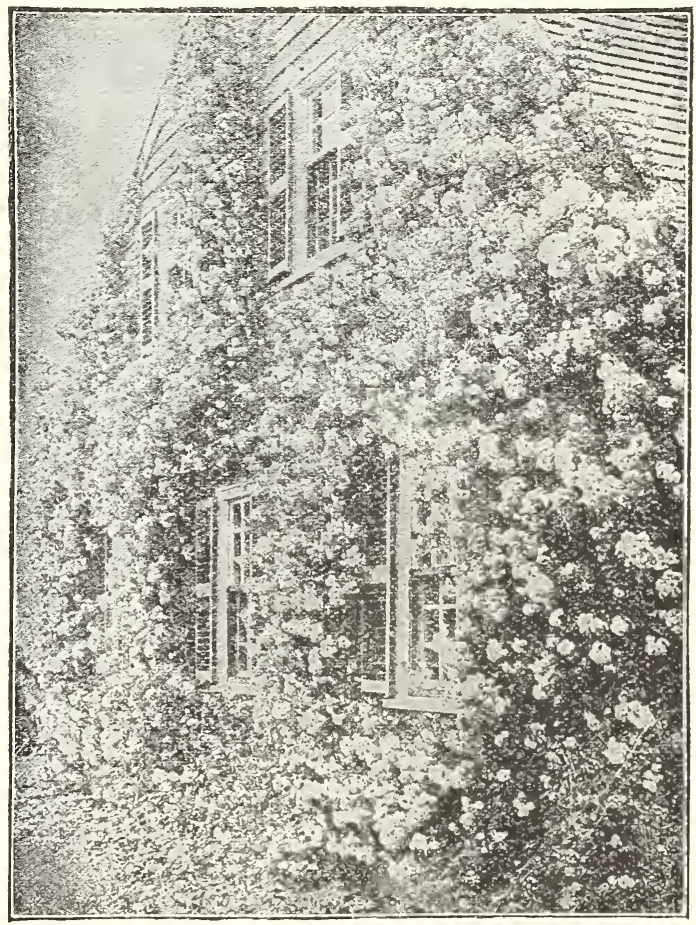

New Rose, Tausendschon 


\section{A Few Cultural Hints About Shrubs}

There is no cheaper and better way to relieve that dreary bleak and cheerless aspect of your home surroundings than by planting a few shrubs of which there are many varieties. But are not all suitable for the same purpose. Care must be taken in selecting them as to their flowering season, height and thrift.

In order to be successful, select small healthy and vigorous plants, as young shrubs are much easier to start than old ones. Buy those that show a healthy condition of growth, firm texture of wood and with abundant fibrous roots.

All that is necessary in planting shrubs is to dig up the soil to a depth of one to two feet. Use a liberal supply of cattle manure or other good fertilizers. Level your ground, then dig the holes. Make them large enough to allow plenty of room for the roots.
Place your shrubs well down and spread out all the roots, then fill the black soil around them first. Place enough soil about the shrubs to raise it somewhat higher than elsewhere and press the soil carefully down with the foot.

Do not plant shrubs in the center of a small lawn, it is far better to set them in corners or along the sides in a zig-zag or crescent fashion, thereby creating a cozy and homelike appearance.

A succession of bloom may be had for about six months of the year by planting the following varieties: Lilacs; Flowering Almonds; Spirea Van Houtte; Bridal Wreath; Spirea Anthony Watterer, crimson; Hydrangea Paniculate, white; Wiegelia Eva Rathke, crimson; and Dutzia, Pride of Rochester, white. These are old favorites and always do well.

NOTE: All Flowering Roots, Shrubs and Treesare sold aceording to size, shape and varieties.

ALvovid, Flowering. A bushy shrub rarely over five feet tall; bearing rose-and bush-colored clouble flowers in early spring. Hardy; very attractive. Specify pink- or white-flowered. 'Heavy plants.

Each

ALTiEA (Rose of Sharon). An attractive hardy shrub, desirable on account of its large, showy blossoms, which appear in August and September. Excellent for a flowering hedge or to grow singly. We have donble red, white, and purple.

ALTHEA. (Tree form). A handsome little tree to plant on the lawn. Double red, white and pink. Wach \$1.00 and uip.

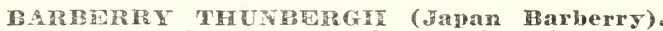
One of the best lawn and border shrubs. Compact low-growing, especially suitable for a hedge or as a border along walks and drives. Foliage a fine brilliant green in summer, turning a deep, autumnal red in fall. Yellow flowers in April to May, then followed by bright scarlet bearries in profusion, which remain fresh until the following spring. Wach boe and up.

CALYCANTHUS (Carolina Allspice, or sweetScented shrub). Handsome plant, growing about 6 feet tall, with large, glossy foliage and spicily fragrant chocolate-red flowers about 2 inches across. Succeeds well in shady or sunny location.

Wach 5oe and up.

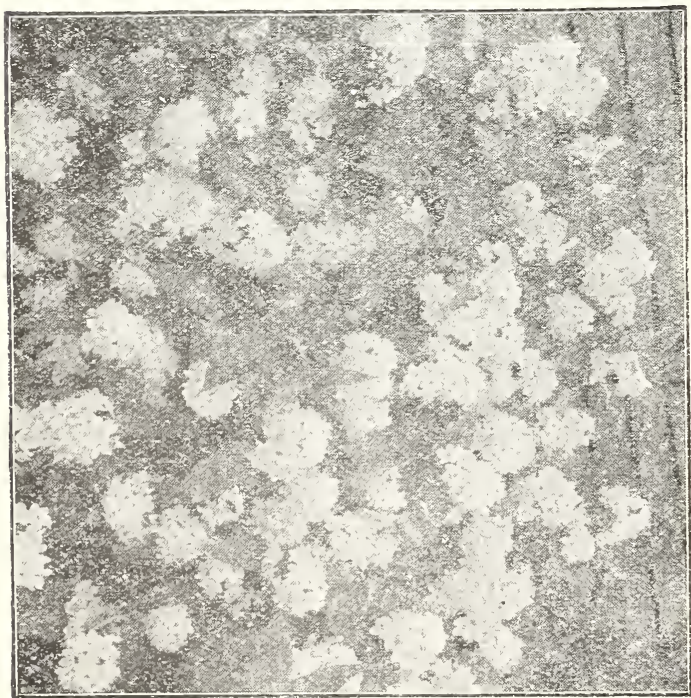

Deutzia Pride of Rochester

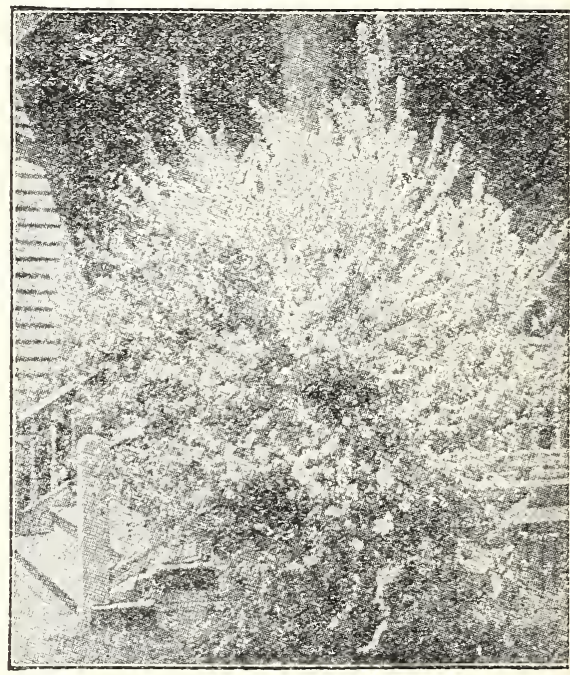

Flowering Almond

CRAB, Bechtel's Dowble Flowering. Of medium growth with flowers of immense size and beautiful pink color; suggesting fragrant double pink roses. Each $\$ 1.50$ and up.

CYDONIA JAPONICA (Japan Quince). This ranks among the choicest of flowering shrubs. men shrub it is very attractive; also fine for borders or groups. The large, brilliant, bright-red flowers appear early in spring, before the leaves, and every branch is covered with bright glossy green foliage all summer. Splendid hedge plant.

Each 50e and up.

CORNUs. Hardy shrubs with handsome foliage, often assuming a brilliant fall coloring and with attractive flowers and fruits. They grow nearly as well in shady places under large trees as in sunny, exposed positions, and thrive in almost any soil. One of our best shrubs.

Siberiea (Siberian Dogwood). Rapidly growing, attaining 6 to $10 \mathrm{ft}$. in height. Clusters of small white flowers appear in May and June. Its chief attraction is the bright-red bark in winter.

Each 50e and up.

DEUTzIAs. The flowers of the Deutzias are tassel-like and clustered into thick wreaths along their drooping branches. The hardihood of these plants, in connection with the rapid growth, luxuriant foliage and profusion of bloom in June, July, lant foliage and profusion of bloom in June, July, and August, makes them deservedly popular. with pink, in racemes four or five inches long.

Each 50c and up.

Pride of Rochester. A week earlier than Double Crenate, which it resembles. Much larger flowers. Each 5oe and up. 
HYDRANGEA. One of the best and most reliable shrubs giving a great abundance of show white flowers in Autumn when blossoms are few. Hardy; grows well in any rich moist soil. To secure large clusters of blossoms, prune back, in the Fall or early spring, the branches of the previous year to 1 to 3 pairs of buds, depending upon the quantity of blossoms desired.

PANICULATA GRANDIFLORA. The most popular and widely planted shrub in cultivation. Adapted to any part of the country, perfectly hardy, cemetery there is no better shrub. Grows 3 to 4 feet high; blooms from August until frost. The fiower panicles are frequently nearly a foot in length, white when they first open, afterwards changing to rose, remaining in good condition for weeks. This shrub should be planted in masses or with background of other shrubbery.

Each \%5e and up.

BUSH HONEYSUCKLE (Lonicera). These shrubs of upright habit with their fragrant flowers and red berries are very decorative. Loniceras thrive in almost any good garden soil, preferring sunny locations. Pruning may for planting in the border or as a hedge.

TARTARICA. A popular variety growing $s$ to 10 feet tall. Produces an abundance of fragrant pink or white blossoms in May and June, followed by red berries in the late Summer and Fall.

Each 50c and up.

FORSYTHIA (Golden Bell). One of the showiest early flowering shrubs with brilliant yellow flowers borne in profusion along the slender branches before the leaves appear. Grows 8 to 10 feet tall in good soil; hardy; excellent for planting in borders.

Fortunei. A spreading bush with upright branches and dark shiny foliage, Deep yellow flowers. Each, 50c and up.

LIGUSTRUM (Hedge Plant). (Privet). They are very valuable for shrubberies with their clean, dark green foliage, which is rarely attacked by insects and keeps its green color mostly unchanged until late Fall, excepting L. Ibota, which turns a purplish hue. The privets are all well adapted for planting as ornamental hedges and do well in the dust and smoke of the city. Hardy, growing well in almost any kind of soil.

AMUREUSE (Amoor River Privet). The Chinese variety, growing upright to a height of 15 feet. Hardier than the other varieties. Dark green leaves which remain on most of the winter. Bears panicles of white flowers in June and July, followed by black berries. The best for hedge planting, and most desirable for this section.

18 to 24 inch, each, 20e; doz., \$2.25.

IBOTA. A valuable hardy Privet for the western and northern states. It is almost evergreen and grows freely in all soils. Compact and regular in form, and bears shearing to any extent. Flowers white and fragrant; leaves long and shiny. A charming shrub for hedges or specimens on the lawn. 18 to 24 inch, 35 e each; dozen, \$3.50.
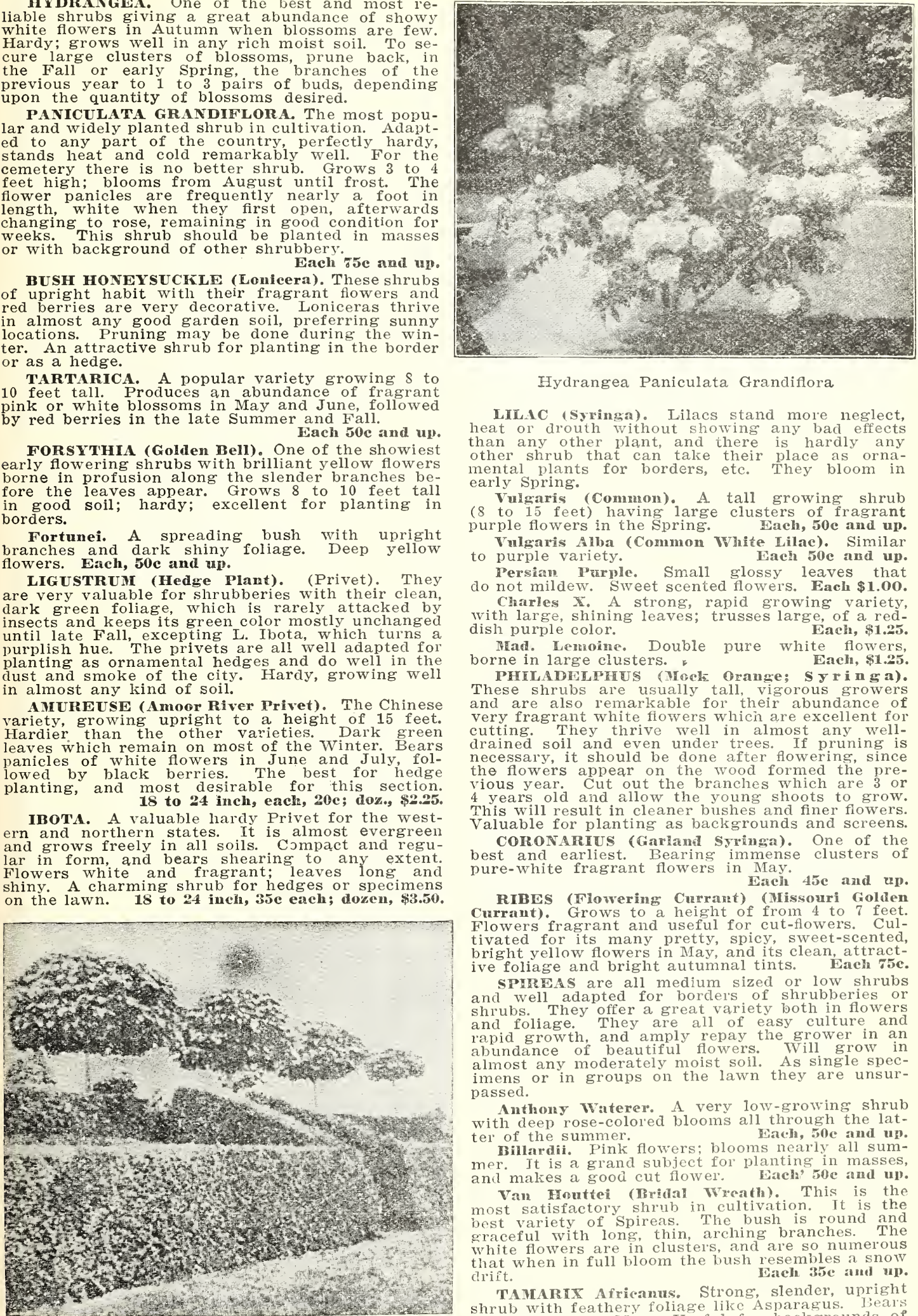

Hydrangea Paniculata Grandiflora

LILAC (Syringa). Lilacs stand more neglect, heat or drouth without showing any bad effects than any other plant, and there is hardly any other shrub that can take their place as ornamental plants

Vulgaris (Common). A tall growing shrub (8 to 15 feet) having large clusters of fragrant purple flowers in the Spring. Wach, 50c and up.

Vulgaris Alba (Common White Lilac). Similar

to purple variety. Each 50e and up.

Persian Prerple. Small glossy leaves that

do not mildew. Sweet scented flowers, Each \$1.oo.

Charles $\mathbf{X}$. A strong, rapid growing variety, with large, shining leaves; trusses large, of a reddish purple color.

FEad I pouble pure white flow borne in large clusters. Each, \$1.25.

PHILADELPHES (Mred- orange; $\mathbf{S}$ y $\mathbf{r}$ ing a). These shrubs are usually tall, vigorous growers very fragrant white fiowers which are excellent fol cutting. They thrive well in almost any welldrained soil and even under trees. If pruning is drained soil and even under trees. If pruning is necessary, it should be done after flowering, since the flowers appear on the wood formed the pre4 years old and allow the young shoots to grow. This will result in cleaner bushes and finer fiowers. Valuable for planting as backgrounds and screens.

CORONARHUS (Garland Syringa). One of the best and earliest. Bearing immense clusters of pure-white fragrant flowers in May.

RIBES (Flowering Currant) (Missouri Golden Currant). Grows to a height of from 4 to 7 feet. Flowers fragrant and useful for cut-flowers. Cultivated for its many pretty, spicy, sweet-scented, bright yellow flowers in May, and its clean, attractive foliage and bright autumnal tints. Each 75e.

SPIREAS are all medium sized or low shrubs and well adapted for border's of shrubberies or shrubs. They offer a great variety both in flowers and foliage. They are all of easy culture and rapid growth, and amply repay the grower in an abundance of beautiful flowers. Will grow in almost any moderately moist soil. As single specimens or in groups on the lawn they are unsurpassed.

Anthony Waterer. A very low-growing shrub with deep rose-colored blooms all through the latter of the summer. Hach, 50e and up.

Billardid. Pink flowers; blooms nearly all summer. It is a grand subject for planting in masses, Van Houttei (Bridal Wreath). This is the most satisfactory shrub in cultivation. It is the best variety of Spireas. The bush is round and white flowers are in cluster's, and are so numerous that when in full bloom the bush resembles a snow

TAMARTX Africanus, Strong, slender, upright shrub with feathery foliage like Asparagus. Beal's pink flowers in May. Useful for backgrounds 5oc. 


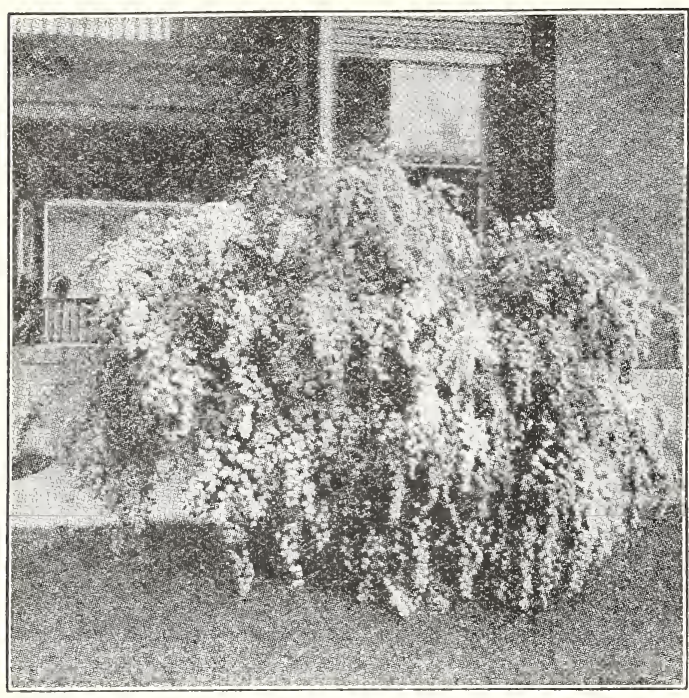

Spirea Van Houttei (Bridal Wreath)

SYMPHORICABEUS (Waxberry). A good native shrub with attractive white berries in autumn and early winter. They are very useful plants for covering the ground under trees, for massing in the edges of beds or borders, or for detached groups where something low is desired. They will thrive in almost any soil. On account of their shrub of bushy form with pink flowers in July, they are very pleasing in the winter landscape.

Racemosus (White Snowberry). A medium shrub of bushy form with pink flower's in July, followed by white waxy berries in the autumn and early winter. Vulgaris (Indian Currand). A low-growing spreading shrub of graceful habit and attractive foliage. Noted for its beautiful clusters of red berries, which are persistent into the winter.

Each 35e and up.

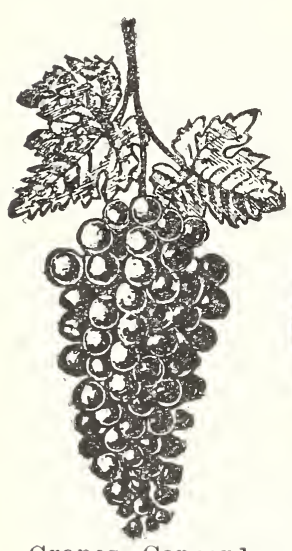

Grapes, Concord

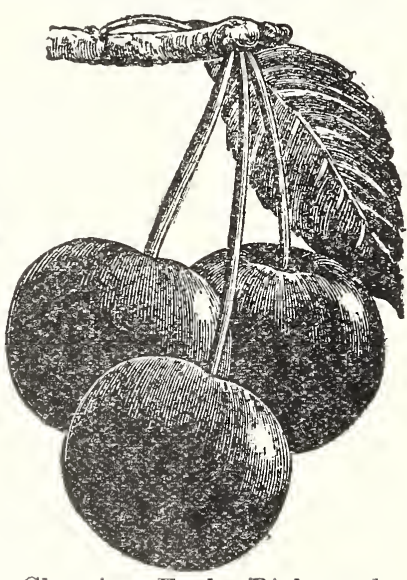

Cherries, Farly Richmond
FiRUIT TREFS. About 5 to 7 feet in height. We have listed only a few of the better varieties which have proved to be the most valuable.

APPLE TIEFS, Sumner Varieties. Red Astrachan. Early Harvest, Yellow Transparent

wach, 75 c and up.

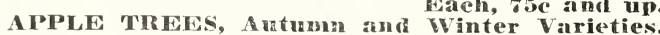
Fameuse (Snow Apple), Maiden's Blush, delicious Winesap. CRAP APPLE TREgS (Hyslop, Whitmey).

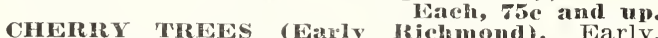
dark red. Each, \$1.00 anmil m.

PEAR TRELS (Bartlet, Hlenish Meanty, Kieffer, Seckel). Cach, $\$ 1.00$ and up.

PHACH TRERS. Farly, medium and late. Each, 50c and up.

PIUM TIREES. Japan or native. Each $\$ 1.25$ and up.
SNOWHALL (Viburnum). A superb much-admired shrub, bearing in June, great clusters of white flowers in the form of a snowball. They are perfectly hardy, grow quickly, and are remarkably free from attacks of insects.

Opulus Sterilis. The common Snowball or Guelder Rose. Broad and handsome leaves. Grows to large size. In May covered with globular clusters of pure-white sterile flowers.

WEIGELIA. Shrubs of erect habit while young. They gradually spread and droop as they grow older. Their time of blooming is after the lilacs are gone, and they produce large trumpet-shaped flowers of all shades and coloris from pure white to red.

IROSEA. Fine rose-colored flowers; one of the best. Hach, 75c and up.

VARIEGA'T. Dwarf in habit; flowers roseblush, smaller than the others; silvery, variegated foliage. Each, 75e and up.

WVA RATKE. The finest Weigelia in cultivation. Trumpet-shaped, carmine-red flowers. wach, $\$ 1.00$ and up.

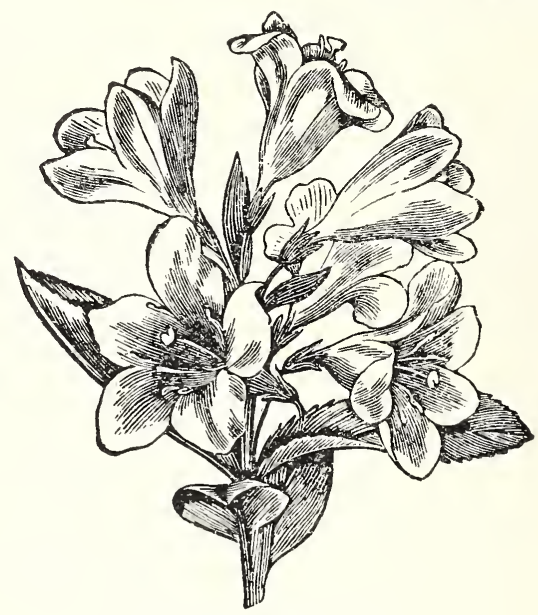

Weigelia Eva Rathke

SHADE 'TRELS. About 8 to 12 feet in height. The following, each $\$ 1.00$ and up, according to size and varieties:

ALIAN'THUS (Tree of Heaven). Rapid grower. CATALPA, Speciosa. (Hardy Catalpa).

CATALPA, Bungei. Umbrella-shaped tree.

ELM (American). Excellent for street planting.

PURPLE NORWAY MAPLE. B e a $\mathrm{t}$ if $\mathrm{l}$ in foliage.

SILVER OR SOFT MAPLE. For street and park planting

SUGAR OR HAIR MAPLE. A fine lawn tree.

WEIR'S CUT-LEAVED MAPLE. Long, slender drooping branches.

Poplar (Carolina). A good tree for street planting.

\section{G R A P E S}

They grow readily in most soils, but a little extra attention as to the soil, pruning and cultivation they receive will result in a better quality of fruit. No part of the fruit garden yields a richer harvest than the vineyard.

CONCOID. One of the best known grapes. Large clusters of round, black berries; flesh moderately juicy; sweet pulp; quite tender when fully BRIGHTON. Jarge handsome bunches of the
(a) bod flavor. An best quality, berries
excellent early grape.

DIMMOND. Bunch large and compact, color greenish white with a yellow tinge when fully ripe, flesh juicy, almost without pulp, quality very good, early.

NIAGis. Bunch medium, with large berry which is slightly pulpy, tender and sweet, ripens with Concord, probably the most valuable white grape in cultivation.

2 year old vines. Fach $25 c$ and up, according to

\section{SPECIAT, NOTE ABOUT MAILING}

Seeds and Bulbs will be mailed if desired. The postage rate is one cent for every two ounces, or 8 cents per pound. Remember to send sufficient postage, otherwise we send by express and the buyer pays the transportation charges. 


\section{Choice Selection of Small Fruits}

Avoiding the long lists of varieties which tend only to confuse the inexperienced planter we offer a selected list of the several sorts we know will give satisfaction.

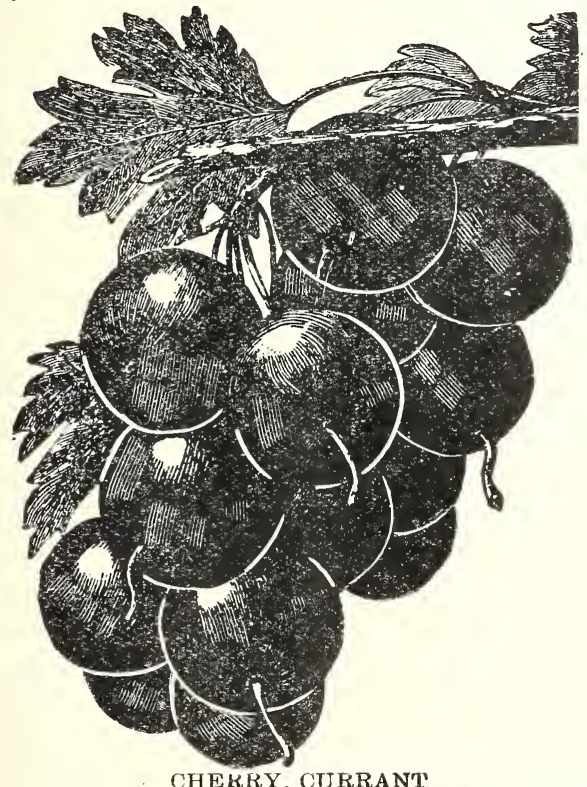

BLACKBERRIES

For garden culture, plant 2 feet apart in rows 3 feet apart. Pinch back canes when 4 feet high and allow three canes to hill. 3 caneg for $25 \mathrm{c}$, dozen $90 \mathrm{c}$.

Early Harvest. A very early productive variety with sweet medium sized berries, two weeks earlier than the Snyder.

Snyder. A hardy, well-known variety, berries of medium size, sweet and melting, producing in profusion, early.

\section{GOOSEBERRIES}

This fruit is $s \in$ useful for cooking when green or ripe, and may be canned with such facility, that it is beginning to be cultívated very extensively for both home and market use. It requires the same cultivation and treatment for worms as the currants.

Downing. Whitish green, vigorous and prolific, of splendid quality for desserts or cooking, fine for general culture.

Houghton. Medium pale red berries, tender and good, very productive and vigorous.

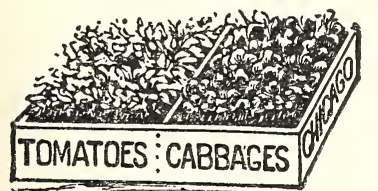

Red Jacket (Josselyn). La r ge smooth berries of good flavor, fruit bright red. The best large variety to plant. 2 year old bushes, each 35 c and up, according to size.

\section{STRA WBERRIES}

Early spring is the best time for setting out. The plants are set 12 in. apart in rows, 18 inches between rows. At the end of the season they will have formed narrow rows of plants. This system will produce more and better berries than where the rows are thickly matted together. A mulch of leaves or straw is to be applied after the ground freezes in vinter; the covering should be removed before growth starts in the spring. Dozi 20s, $5075 \mathrm{c}, 100 \$ 1.25$.

Brandywine. Berries very large, broadly heart-shaped, bright red in the center, firm flesh, a fine flavor, a late berry.

Senator Dunlap. One of the best flavored berries, fruit of good size,

Vegetable Plants

In their seasons for planting we have live, fresh plants of Cabbage, Caulitower, Tomato, Pepper, etc.

\section{CURRANTS}

Plant 3 feet apart in a row and keep vines growing in good condition as soon as it has rruited to give vigor tc Cuthbert. Large, dark red variety, producing large crops of large
nical deep berries which are sweet, high flavored, a certain cropper ly be planted in the spring and the youn ft. high to keep the bushes snug and compact. 3 canes for $25 \mathrm{c}$, doz. $90 \mathrm{c}$.

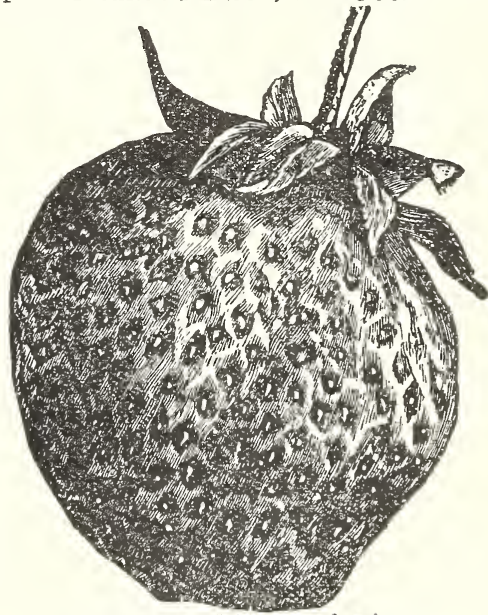

STRAWBERRY, Braudywine

\section{AAPBERRIES} regular form, beautiful bright red, firm, splendid keeper, one of the besi for canning, ripens early.

William Bolt. Berries large, conical, rather long, bright red, glossy, quality good, moderately firm, plants vigorous, healthy and quite prolific 


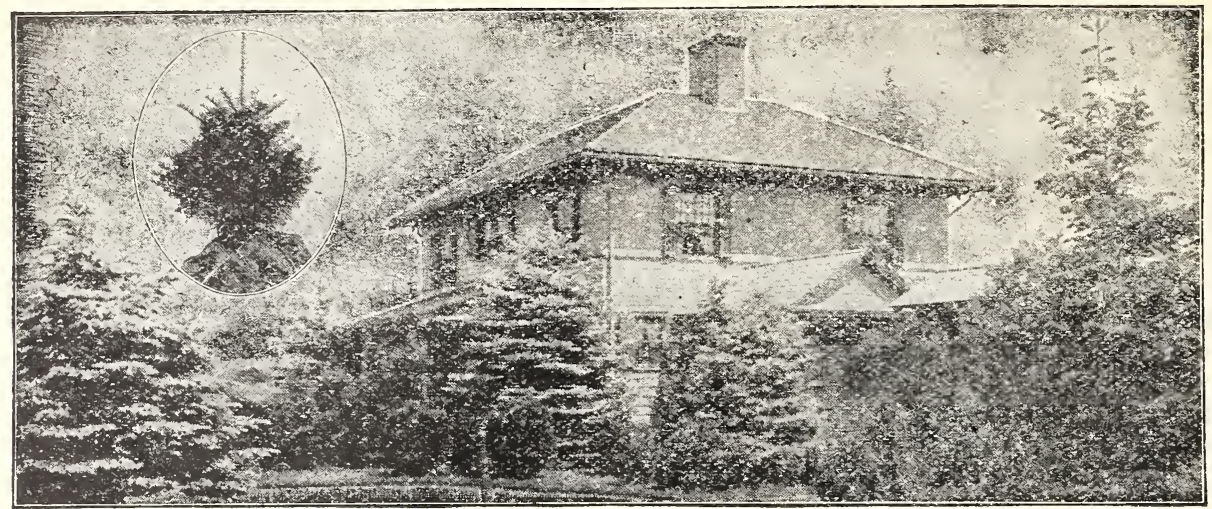

\section{Hardy Coniferious Evergreens.}

No home ground, whether lawn or garden, is quite complete without at least a few of these handsome little trees with their brilliant and wide diversity of colors, ranging in various shades of light green, golden, silver and blue makes them most desirable for beautifying the home grounds or cemetery plot. Being covered with thick and dense foliage the entire season they promote a cheerful and ornamental aspect to the desolate landscape during the dreary winter months. The best soil for evergreen is a well-drained sandy loam. To be successful, transplanting should be done at a time when the trees are dormant. This permits planting during the early spring-April and May-and also in September.

We offer varieties which are the most useful to the general planter and the most in demand.

Handsome little trees, $\$ 2.00$ and up, according to size and variety.

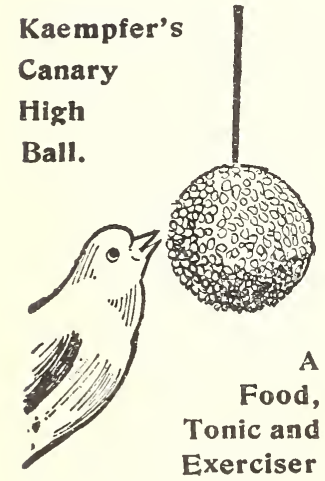

\section{BIRD SEED.}

To make happier and healthier birds we have fresh and clean seed in bulk and packages; also the leading brands of bird seeds, remedies, tonics and supplies.

To have your birds happy, healthy and sing feed them on KAEMPFER'S CANARY HIGHBALL and BIRDOLENE - a tonic and exerciser.
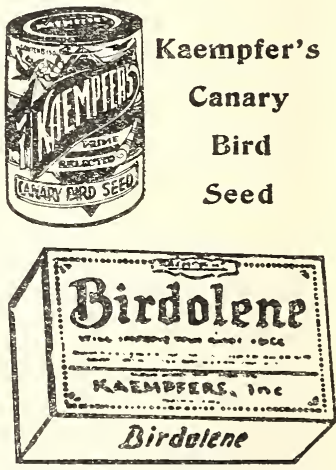

Kaempfer's Birdolene A real song restorer.

\section{"Say It With Flowers."}

Flowers are nature's most precious gifts. They create a lingering sentiment which words cannot express.

Your orders for seasonable cut flowers, beautifully and artistically arranged floral emblems, will be conscientiously served. Careful and prompt delivery assured. 


\section{Flower Pots, Saucers, Pans, Hanging Baskets and Vases}

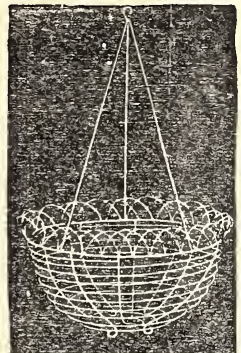

Wire Hanging Basket

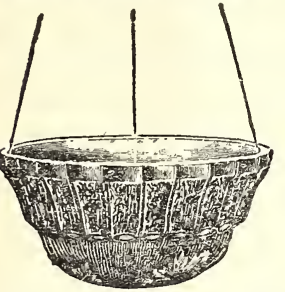

Earthenware Hanging Basket Earthenware

Hanging Basket

Diam.

7-in. .... \$ach

8 -in. .... . . . . .

9 -in. ..... 60

10 -in. ........ 75

12-in. .... .90

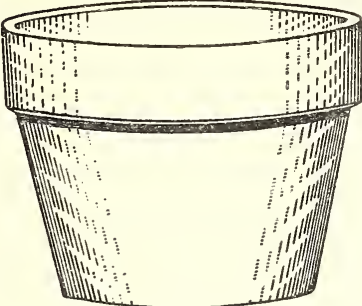

Bulb or Fern Pan

Saucers

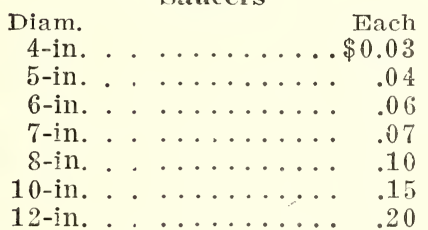

Fern Dish Hiners

Diam.
5 -in. ....... $\$ 0.07$

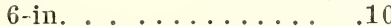

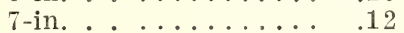

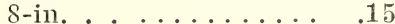

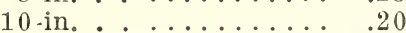

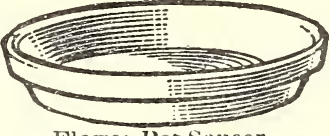

Flower Pot Saucer

Flower Pots

Diam. Each Diam.

2-in. ..\$ \$0.02 7 -in.

3-in. ... .03 8-in.

4-in. ... .04

5-in.... . . . . 07

6-in.... 10

9-in.

10 -in.

12 -in.

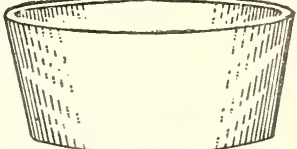

Fern Dish Liner

\section{Each}

$\$ 0.15$

.20

.30

.45

.65

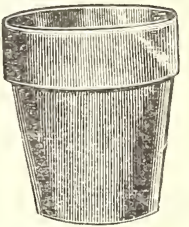

Fern and Bulb Pams
Fach

6 -in. . ..... \$0.10

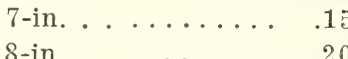

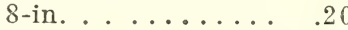

9 -in......... .30

10-in...........45

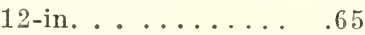

Wire Hanging Baskets

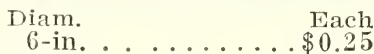

8 -in........ .30

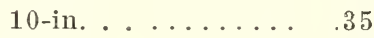

12 -in.................. 45

GIASS CEMETERY VASE

Mrade of hard crystal glass. On account of its fine appearance and serviceable gualities, makes this an ideal cemetery vase. Price, 10 inches, cach :3ə̃c; 16 inches, each 150.

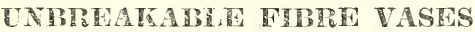

For holding cut-flowers, mahogany finish. Very durable, 4 inches diameter, 9 inches deep. Lach 91.25 .

White Whameled Lawn or Cemetery Vase

A pleasing and useful article often used on lawns and in cemeteries where the rules forbid the use of glass vases. Made of heavy tin sheeting, enameled in white and green, making an attractive vase for this purpose.

Height $63 \frac{1}{4}$ inches, Diameter $4 \frac{1}{4}$ inches, each $35 \mathrm{c}$

Height $6 \frac{1,4}{1}$ inches: Diameter $3 \frac{1}{2}$ inches, each $30 \mathrm{c}$

\section{NOTR-Above Prices are Subject to Market Changes}

\section{FALL-BEAPING STRA WBERPILS}

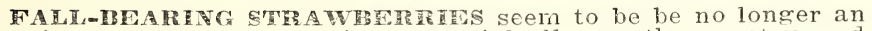
experiment, they are becoming essential all over the country, and are making god every place they have been tested. If these varieties are disbudded, until say August 15 th to September 1 st, and allowed to fruit, they will sive large quantities of ripe berries until checked by hard freezing. The two varieties we offer we consider the best.

PIOGREATIT. This is the strongest growing plant of all the fall-bearing varieties we have seen. The plants are very large and heavily rooted. producing a phenomenal crop of medium to large fruits, of a dark red color both inside and out. The young plants are produced in good quantities.

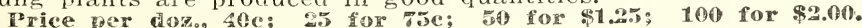

Note-Prices quoted in this catalogue do not include postage or expressage.

Pareel Post Bates-All parcels of seeds, bulbs and plants up to and including 8 oz at the rate of $1 \mathrm{c}$ for each 2 oz. regardless of distance; over 8 oz. at the zone rate.

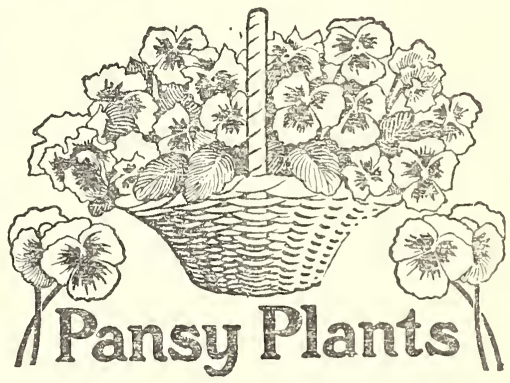

\section{FLOWIRING BEDDING PLANTS}

We carry in season seedling plants of pansies, asters and daisies. Also geraniums and other pot grown blooming plants. 


\section{Lawn and Garden seeds}

Flowering

Bulbs

Shrutos

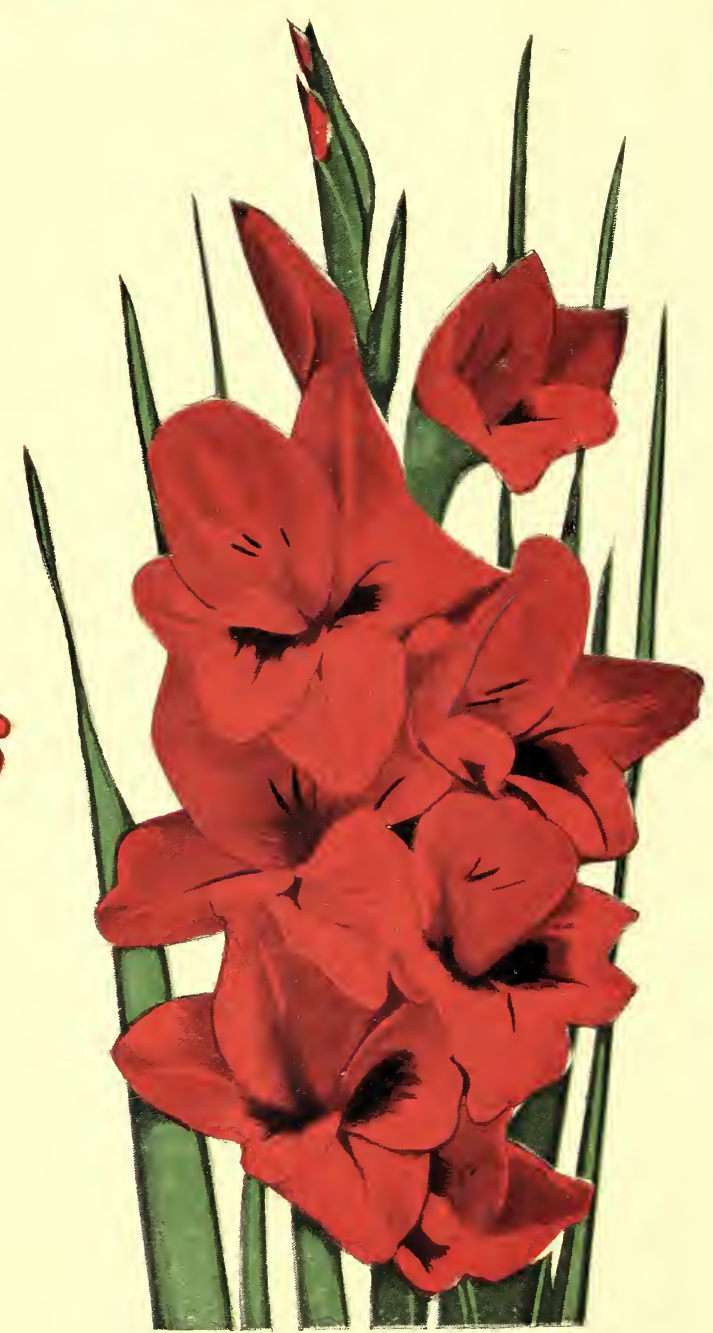

SPRING

1928

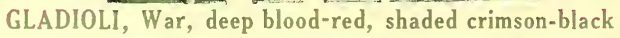
(SEE PAGE 21)

\section{WILLIAM MARKS Seedsman and Florist}

